UNIVERSIDADE DE SÃO PAULO

FACULDADE DE EDUCAÇÃO

FERNANDA CAMPAGNUCCI

\title{
SILÊNCIO DOS PROFESSORES?
}

UMA INTERPRETAÇÃO SOCIOLÓGICA SOBRE A “AUSÊNCIA” DA VOZ DOCENTE NO JORNALISMO EDUCACIONAL

SÃo PAULO

2014 


\section{SILÊNCIO DOS PROFESSORES?}

\section{UMA INTERPRETAÇÃO SOCIOLÓGICA SOBRE A “AUSÊNCIA” DA VOZ DOCENTE NO JORNALISMO EDUCACIONAL}

Dissertação apresentada ao Programa de Pós-Graduação da Faculdade de Educação da Universidade de São Paulo para obtenção do título de Mestre em Educação.

Área de Concentração:

Sociologia da Educação

Orientadora: Profa. Dra. Maria da Graça Jacintho Setton

SÃo PAULO 
AUTORIZO A REPRODUÇÃO E DIVULGAÇÃO TOTAL OU PARCIAL DESTE TRABALHO, POR QUALQUER MEIO CONVENCIONAL OU ELETRÔNICO, PARA FINS DE ESTUDO E PESQUISA, DESDE QUE CITADA A FONTE.

Catalogação na Publicação

Serviço de Biblioteca e Documentação

Faculdade de Educação da Universidade de São Paulo

$37.047 \quad$ Campagnucci, Fernanda

C186s Silêncio dos professores? Uma interpretação sociológica sobre a "ausência" da voz docente no jornalismo educacional / Fernanda Campagnucci; orientação Maria da Graça Jacintho Setton. São Paulo: s.n., 2014.

133 p.; anexos

Dissertação (Mestrado - Programa de Pós-Graduação em Educação. Área de Concentração: Sociologia da Educação) - Faculdade de Educação da Universidade de São Paulo.

1. Socialização 2. Professores 3. Educação 4. Meios de comunicação

I. Setton, Maria da Graça Jacintho, orient. 
Nome: CAMPAGNUCCI, Fernanda

Título: Silêncio dos Professores? Uma Interpretação Sociológica sobre a "Ausência" da Voz Docente no Jornalismo Educacional

Dissertação apresentada ao Programa de Pós-Graduação da Faculdade de Educação da Universidade de São Paulo para obtenção do título de Mestre em Educação.

Aprovado em:

\section{Banca Examinadora}

Prof. Dr.

Instituição:

Julgamento:

Assinatura:

Prof. Dr.

Instituição:

Julgamento:

Assinatura:

Prof. Dr.

Instituição:

Julgamento:

Assinatura: 


\section{RESUMO}

Muitos são os agentes presentes hoje na cobertura da imprensa sobre educação: organizações não governamentais, políticos, pesquisadores, empresários. No entanto, constata-se a ausência da opinião dos professores da educação básica, apesar de estes se encontrarem em posição privilegiada para avaliar a execução das políticas educacionais. Esta pesquisa identifica e analisa o "silêncio dos professores" como uma construção social. Parte da hipótese de que se articulam nesse processo de silenciamento fatores de ordem objetiva e de ordem subjetiva. Como expressão de ordem objetiva, destacam-se o contexto de desvalorização social e econômica do papel do professor, as representações que circulam no imaginário social a respeito da docência e a existência de mecanismos legais, administrativos e burocráticos que tolhem sua liberdade de expressão. Como elementos de ordem subjetiva, salienta-se a dinâmica da identidade profissional docente, construída e assimilada a partir de um panorama de desvalorização e suas percepções sobre seu papel no debate educacional. Buscou-se compreender de que maneira esses fatores se articulam, a partir do aporte das teorias da socialização contemporâneas. Para desenvolver esse argumento, foram coletados dados secundários sobre o professorado e a docência no Brasil em fontes acadêmicas e midiáticas, e realizadas dez entrevistas em profundidade com professores da rede estadual de ensino de São Paulo.

Palavras-Chave: socialização, ofício docente, educação, mídia. 


\begin{abstract}
There are many agents whose opinions are present in the current media coverage on education: nongovernmental organizations; politicians; researchers; entrepreneurs. However, one can verify the absent voice of teachers, despite their quite privileged position to evaluate public education policies. This research identifies and analyzes the "silence of teachers" as a social construction. We start from the hypothesis that both objective and subjective factors interact in this process. Among the objective aspects, we highlight the context of economic and social depreciation of teachers' role; the representations which circulate in social imaginary concerning teaching; and the existence of legal, administrative, and bureaucratic mechanisms that restricts their freedom of expression. As for subjective aspects, we emphasize the dynamics of teachers' professional identity - which is constructed and assimilated from a devaluation context - as well as teachers' perceptions about their role in the educational debate. In order to understand in which ways the aforementioned factors interact, we relied on the contemporary theories of socialization. To further develop this argument, we collected secondary data about teachers and the act of teaching in Brazil from academic and media sources, and we conducted in-depth interviews with ten teachers within the São Paulo state school system.
\end{abstract}

KEY-WORDS: socialization; teachers; education; media 
À Professora Edna, minha mãe, que levou e continua a levar, há quase 40 anos, inteligência, sensibilidade e bom humor a escolas públicas de São Paulo; assim como já o tinha feito, décadas antes, sua mãe e minha querida avó, Professora Iraci Pereira (in memoriam). 


\section{Agradecimentos}

Às professoras e aos professores que dedicaram seu tempo a esta pesquisa, sobretudo aos dez que gentilmente concederam entrevistas sobre suas vidas e trabalho;

À Professora Maria da Graça Jacintho Setton, responsável por meu encantamento pela Sociologia e por indicar os caminhos para meu amadurecimento acadêmico e intelectual;

À minha família, com quem estive menos do que gostaria nesses últimos três anos, mas que, ao menos em pensamento, esteve comigo todo o tempo, ajudando-me a seguir em frente;

Aos colegas pesquisadores do Grupo de Práticas de Socialização Contemporâneas - Ana Paula Sefton, Elias Evangelista Gomes, Gabriela Valente, Lisandra Ogg Gomes, Michelle Prazeres e Rodrigo Ratier - pela sempre enriquecedora interlocução;

À Coordenação de Aperfeiçoamento de Pessoal de Ensino Superior (CAPES), pela concessão de bolsa de pesquisa em parte desse período;

A todos os mestres e companheiros que tive a oportunidade de encontrar na Ação Educativa, pelos anos de aprendizado cotidiano e inspiradora convivência, fundamentais à concretização deste trabalho. Não poderia deixar de agradecer especialmente, entre essas pessoas, a Denise Carreira, Ester Rizzi, Mariângela Graciano, Raquel Souza, Regina Costa, Regina Oshiro, Salomão Ximenes, Sérgio Haddad, Thais Bernardes e Vera Masagão.

Se o trabalho de pesquisa é, nas palavras de Charles Wright Mills, "artesanato intelectual", também é preciso agradecer a outras pessoas que fizeram parte dessa teia criativa e afetiva, inspirando, apoiando ou contribuindo, de alguma forma: Ana Paula Severiano, André Albert, Beatriz Rey, Daniel Cara, Dany Secco, Diego Vega, Eduardo Amaral, Fabiano Angélico, Iracema Nascimento, José Muniz Jr., José Quibao Neto, Karina Yamamoto, Luís Fernando dos Reis Pereira, Leandro Salvador, Miguel Said Vieira, Mauricio Savarese, Paulo Saldaña, Patrícia Cornils, Silvia Tavares, Tiago Fassoni e Wagner Santana. 


\section{SUMÁRIO}

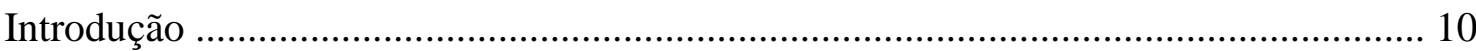

Capítulo 1 - Os Contornos do Silêncio ....................................................................... 20

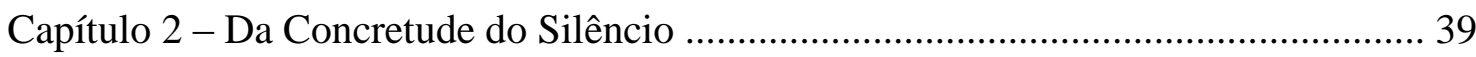

Capítulo 3 - A Subjetivação do Silêncio - Uma Construção Social ............................. 75

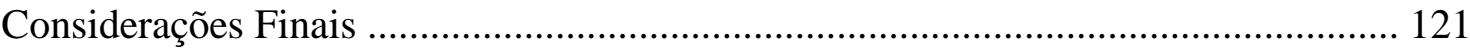

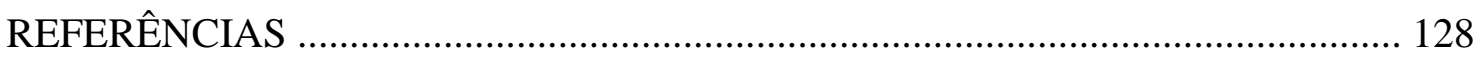

ANEXO - ROTEIRO PARA ENTREVISTA SEMIESTRUTURADA .................... 131 


\title{
INTRODUÇÃ̃O
}

\begin{abstract}
Um dos traços centrais, perenes do ofício de mestres, é manter a memória coletiva acesa, não compactuar com os silêncios, ou não silenciar a história às novas gerações. Estamos entre os homens e mulheres da memória. Que belo ofício, tão silenciado.
\end{abstract}

Miguel Arroyo, Ofício de Mestre: Imagens e Autoimagens.

A análise do tratamento da imprensa brasileira à educação (ANDI, 2005, 2009; AÇÃO EDUCATIVA, 2007a, 2007b, 2010; CITELLI, 2012; FERREIRA, 2012) revela que, dentre todos os agentes envolvidos no processo educativo ou na execução das políticas educacionais, o professor da etapa básica de ensino é aquele que menos é tomado como fonte pelos meios de comunicação. Se, ainda que em diferentes níveis de legitimidade e autoridade, pesquisadores, empresários, pais, mães e estudantes são chamados a manifestar suas opiniões, os docentes tendem a aparecer nas reportagens como "personagens" - jargão jornalístico para designar pessoas que apenas ilustram determinada abordagem desenvolvida pelo repórter.

Podem ser consideradas como exceções as situações em que os professores são ouvidos para opinar sobre uma política implantada em sua localidade, ou para falar de suas experiências e práticas educativas como autoridade no assunto. Por outro lado, muitas vezes são apontados como responsáveis pelo mau desempenho dos alunos em avaliações, ou ainda julgados pela própria atuação em resultados de avaliações da categoria, sem que sejam ouvidos - ou, mais concretamente, sem que o texto traga "aspas" contendo suas falas - sobre o tema.

É essa flagrante ausência da voz dos docentes da educação básica no jornalismo educacional - e, de forma ampliada, no debate educacional brasileiro - que nomeamos, aqui, como o "silêncio dos professores". A partir dessa constatação, a presente pesquisa tem como objetivo identificar e analisar o processo de construção desse silenciamento. Interessa-nos compreender de que forma ele acontece e de que maneira o silêncio, como 
característica de grupo, é incorporado (e se é de fato incorporado) às práticas individuais dos docentes.

Habituados que estamos a posicionar em polos opostos conceitos como indivíduo e sociedade, a ação dos sujeitos e a estrutura a que pertencem, os constrangimentos que sofrem e sua autonomia, parece-nos inevitável a pergunta: os professores silenciam ou são silenciados?

Neste estudo, procuramos contornar essa falsa dicotomia e mostrar caminhos para outro entendimento do problema, que passa a ser reformulado da seguinte maneira: como o silêncio é construído socialmente? E como se articulam, nesse processo, fatores de ordem objetiva e subjetiva da vida do professorado e da sociedade em que vivem? Em outras palavras, se o silêncio é dos professores, os sujeitos silenciam; no entanto, há uma trama social muito mais ampla e complexa, de que eles fazem parte e que ajudam a tecer, mas que, ao mesmo tempo, os condiciona, "amarra", forma e conforma atitudes: atualmente, silencia.

Mas o que faz com que os professores adotem uma postura silenciosa diante do debate público ou, ao contrário, envolvam-se nele? Quais são os processos que influenciam na definição dessa situação - a atual ausência dos professores no debate educacional?

A perspectiva teórica com a qual esses problemas são abordados, aqui, inscrevese nos estudos da chamada socialização contemporânea. Com esse quadro conceitual, é possível compreender o silêncio dos professores como uma construção social, processo do qual estes participam e que é decisivo para a constituição de suas identidades pessoais e profissionais. Parte-se do suposto de que olhar o problema em seu aspecto institucional (o silenciamento a partir de mecanismos burocráticos existentes) é insuficiente para elucidá-lo; faz-se necessário, para tanto, analisá-lo também em termos sociopsicológicos, que permitam investigar subjetividades.

A perspectiva teórica dos processos de socialização ajuda a promover esse diálogo entre as análises sobre as estruturas sociais e as estruturas mentais dos indivíduos em determinada sociedade. Objeto de estudo da sociologia clássica, a socialização pode ser definida como "a ampla e consistente introdução de um indivíduo no mundo objetivo da sociedade ou de um setor dela", de acordo com Berger e 
Luckmann (2011). Contudo, novos conceitos e novas concepções de socialização surgem a partir dos anos de 1980, e podem ser resumidas, como o fez Claude Dubar (2005), na expressão "construção social da realidade". Longe de ser passivo, esse processo envolve permanente negociação, sendo esta uma relação dialética entre as realidades estruturais e o envolvimento humano na construção da realidade ${ }^{1}$. No mundo contemporâneo, coexistem múltiplas instâncias e matrizes de cultura que participam dessa construção, de forma interdependente - família, escola, religião, mídia - ao longo de toda a vida de um indivíduo.

O que essa concepção de socialização traz de importante com relação a definições anteriores mais "deterministas" ou "mecanicistas" do mundo social é que, se a entendemos como "construção de um mundo vivido",

então esse mundo também pode ser desconstruído e reconstruído ao longo da existência. A socialização se torna um processo de construção, desconstrução e reconstrução de identidades ligadas às diversas esferas de atividade (principalmente profissional) que cada um encontra durante sua vida e das quais deve aprender a tornar-se ator. (DUBAR, 2005, p. XVII)

A noção de socialização, portanto, é ampliada com relação à ideia de integração vinculada a uma tradição sociológica, passando a ser entendida como

uma noção definidora de um conjunto expressivo de práticas de cultura que tecem e mantêm os laços sociais [...] como uma área de investigação que explora as relações indissociáveis entre individuo e sociedade; na sua dimensão produtora difusora e reprodutora, a socialização pode enfocar as instituições como matrizes de cultura, pode enfatizar as estratégias de transmissão e portanto de transformação dos grupos sociais bem como pode explorar as disposições de cultura incorporadas pelos indivíduos ao longo de suas experiências de vida. (SETTON, 2008, p. 1)

É importante dizer, portanto, que estão implicados no processo de socialização

Berger e Luckmann definem realidade como "qualidade pertencente a fenômenos que reconhecemos ter um ser independente de nossa própria volição (não podemos 'desejar que não existam')" e por "conhecimento" entendem "a certeza de que os fenômenos são reais e possuem características específicas" (2011, p. 11). A sociologia, então, deve ter por objeto "o que os homens conhecem como 'realidade' em sua vida cotidiana" e é "este 'conhecimento' que constitui o tecido de significados sem o qual nenhuma sociedade poderia existir" (op. cit., p.29). 
vivido pelos professores diferentes momentos, espaços, atores, relações e instituições: o professor em seu processo de formação inicial, apreendendo e gerando esquemas e concepções sobre seu futuro papel; o professor no cotidiano escolar (trabalho), interagindo com colegas, com a estrutura burocrática e com estudantes e suas famílias; o professor diante da mídia, como produtor de sentidos ou como uma representação social, identificando-se com ela ou rejeitando-a para si; o professor em sua vida privada, na interação com sua família ou próximos; o professor diante de um público específico, da sua esfera de atividade profissional; o professor em interação face a face com jornalistas, dentre outras situações. Cada uma delas engendra processos identitários e "estratégias de apresentação de si" (GOFFMAN, 2008, 2009) distintas, que serão, em alguma medida, abordadas ao longo deste estudo.

No entanto, essa diversidade de situações impõe uma certa dificuldade de apreensão do fenômeno - por exemplo, o silêncio do professor pode manifestar-se como opção diante de um jornalista, mas provavelmente não o será diante de um colega de profissão. Por isso, mais do que refletir sobre essas situações de interação, fez-se interessante notar como esses processos de socialização - que também incluem "ações difusas, assistemáticas, não intencionais e inconscientes", conforme indica Setton (2008) - resultam, em grande medida, na ausência do professorado no debate público sobre educação.

A liberdade de palavra, como instrumento dos ideais democráticos, costuma ser justificada com base na sustentação de dois objetivos: a) o de promover um debate público robusto e diversificado e b) o de ser um veículo para a realização da igualdade política (SILVA, 2009). Mais do que isso, a liberdade de expressão é um direito humano fundamental, assegurado em pactos e declarações. O artigo $19^{\circ}$ da Declaração Universal dos Direitos Humanos (1948) determina que "todo ser humano tem direito à liberdade de opinião e expressão; este direito inclui a liberdade de, sem interferência, ter opiniões e de procurar, receber e transmitir informações e ideias por quaisquer meios e independentemente de fronteiras" $"$.

No Brasil, tal direito é garantido a todos pela Constituição Federal de 1988, principalmente nos artigos $5^{\circ}$ (inciso IV - "é livre a manifestação do pensamento, sendo vedado o anonimato") e $220^{\circ}$ ("a manifestação do pensamento, a criação, a expressão e

2 ONU. Declaração Universal dos Direitos Humanos, Paris, 1948. 
a informação, sob qualquer forma, processo ou veículo não sofrerão qualquer restrição") ${ }^{3}$.

Para que se cumpram os objetivos da democracia de promover um debate público vigoroso e diversificado e realizar a igualdade política, a liberdade de expressão deve ser institucionalizada, levando em conta não só os interesses expressivos dos indivíduos - seu direito de falar -, mas também os interesses expressivos da sociedade como um todo - o interesse a ter acesso a um conjunto diversificado de discursos (SILVA, 2009). A livre expressão do professor, portanto, além de favorecer o debate público, seria indispensável para a existência de um ambiente plural e democrático necessário para o processo educativo e para o controle social das políticas públicas educacionais. Essa é também uma garantia constitucional, expressa nos princípios da gestão democrática do ensino e da liberdade de aprender, ensinar, pesquisar e divulgar o pensamento, a arte e o saber ( $\mathrm{CF} / 88$, art. 206, incisos VI e II, respectivamente).

Mas não se pode ignorar que o discurso, para realizar-se dessa maneira, depende da existência de condições de produção favoráveis que, conforme veremos neste trabalho, não são dadas no presente momento aos professores. Além disso, e embora este não seja o enfoque desta pesquisa, Bourdieu (1997) não nos deixa perder de vista que tanto o conteúdo como a força simbólica desse discurso dependem, também, da posição do agente no espaço social, cuja distribuição de capitais e de poder correspondente é desigual. Os pontos de vista são, assim, visões parciais tomadas a partir de um determinado ponto do espaço social, e contribuem para "fazer, desfazer e refazer o espaço, numa luta de pontos de vista, de perspectivas, de classificações"4 (BOURDIEU, 1997, p. 264).

Ao mesmo tempo em que é importante reconhecer o papel dos agentes na construção social da realidade, Bourdieu nos lembra que essa construção obedece a princípios, individuais e coletivos, que são produzidos a partir da posição que os agentes ocupam no mundo social. As disposições ou predisposições para o debate ou, neste

3 BRASIL. Constituição (1988). Constituição da República Federativa do Brasil. Brasília: Senado Federal, 1988.

4 Do original em francês "[...] ces prises de position sur le monde dépendent dans leur contenu et leur force symbolique de la position que ceux qui les produisent y occupent et seule l'analysis situs permet de construire ces points de vue en tant que tels, c'est-à-dire en tant que vues partielles prises à partir d'un point ( situs)dans l'espace social. Cela sans oublier que ces points de vue déterminés sont aussi déterminants: ils contribuent, à des degrés differents, à faire, à défaire et à refaire l'espace, dans la lutte des points de vue, des perspectives, des classements". 
caso, para o silenciar-se, são ajustadas com base em um conhecimento prático dos agentes, que orientam suas intervenções nas lutas simbólicas da existência cotidiana. É dessa maneira que, silenciosos e silenciados, os professores acabam por participar da construção do silêncio - não sem alguma resistência, como observa o autor: "o conhecimento que ocasiona a incorporação da necessidade do mundo social, sob a forma do senso de limites, é bastante real, como a submissão que ele implica e que às vezes se exprime nas constatações imperativas da resignação [...] E ele não exclui [...] formas de resistência, seja passiva ou interior, seja ativa e por vezes coletiva" ${ }^{5}$ (BOURDIEU, 1997, p. 266). Por isso, as ciências sociais não podem "reduzir-se a uma objetivação incapaz de dar lugar ao esforço dos agentes para construir sua representação subjetiva deles mesmos e do mundo, às vezes direcionadas e contra todos os dados objetivos"6 (BOURDIEU, 1997, p. 272).

Será importante, nesse sentido, problematizar essa ausência: estarão os professores de fato ausentes do debate ou participam e vivem essas discussões no cotidiano da escola, mas estão invisibilizados no espaço/debate público mais amplo? A ausência, nesse caso, não significaria "alienação", no sentido de estar alheio às discussões que mobilizam o campo educacional, mas uma privação de visibilidade, de não acolhimento de sua voz no espaço público.

Esta pesquisa se propôs a olhar não apenas para os professores e suas autoimagens e representações, mas também se dedicou a analisar as condições objetivas em que se exerce a profissão docente hoje, e sua interdependência em relação a outros agentes do campo educacional - a comunidade escolar, a burocracia, a mídia - como chave para a compreensão de seu silêncio na cobertura educacional. Além disso, preocupou-se em observar a dimensão processual dessa construção, relacionando essa ausência dos professores não só com a história da docência no Brasil, como também com as formas de socialização contemporâneas. Essa opção metodológica, segundo Norbert Elias, é importante para a compreensão dos fenômenos sociais, porque

5 Traduzido do original em francês: "La connaissance que procure l'incorporation de la nécessité du monde social, sous la forme notamment du sens des limites, est bien réelle, comme la soumission qu'elle implique et qui s'exprime parfois dans les constats impératifs de la résignation (...). Et elle n'exclut pas (...) des formes de résistence, soit passive et intérieure, soit active et parfois collective".

6 "La science sociale ne peut pas se réduire à une objectivation incapable de faire sa place à l'effort des agents pour construire leur répresentation subjective d'eux-mêmes et du monde, parfois envers et contre toutes les donnés objectives (...)". 
dificilmente os problemas sociológicos podem ser enquadrados de maneira satisfatória quando parecem concernir exclusivamente a fenômenos sociais de um local e de um momento exatos - a estruturas que, para usar a linguagem cinematográfica, têm a forma de um plano fixo. Eles só se aproximam mais daquilo que se pode observar, levando a explicações globais, quando são concebidos como problemas de fenômenos que têm a forma de processos, que fazem parte de um movimento temporal. (ELIAS; SCOTSON, 2000, p. 59)

Por fim, a pesquisa também considera os estudos da ação coletiva docente, ainda que não esteja inscrito nessa perspectiva. A identidade coletiva é uma das dimensões da identidade pessoal, e por isso importante para se pensar o grau de engajamento de um indivíduo em um grupo. Olhar para o indivíduo professor não significa deixar de lado sua dimensão de ator coletivo/social: vamos partir da análise da construção de sua identidade profissional neste modelo societário marcado pelo processo de individualização. Soma-se a isso o fato de alguns autores apontarem para uma crise da ação docente, que "consiste no declínio de um determinado modelo de engajamento, o qual, por outro lado, aponta para a possível recomposição desse agir em um período de baixa visibilidade ou latência" (VIANNA, 1999, p. 197).

Para desenvolver a análise do silêncio dos professores, esta dissertação se estrutura em três capítulos.

O primeiro, "Os Contornos do Silêncio", destina-se a definir com mais precisão o problema e o objeto desta pesquisa, apresentando elementos que permitem afirmar que vivemos uma situação de ausência dos professores da educação básica na cobertura educacional promovido pelo mídia e, de forma mais ampla, do debate público da área. Nesse capítulo, serão expostos ainda os argumentos que apoiam a formulação de nossa hipótese - o silêncio resultaria de uma articulação de múltiplos fatores, uma construção social que não se esgota no tratamento midiático ao tema.

No segundo capítulo, "Da Concretude do Silêncio", valemo-nos das entrevistas realizadas para descrever a complexa trama da estrutura social em que se inserem os professores hoje. Serão levantados dados e análises que nos permitam conhecer seu perfil socioeconômico e cultural; as transformações do mundo da docência nas últimas décadas e suas atuais condições de trabalho; as representações que circulam na mídia a respeito dos docentes; elementos que demonstrem a situação de desvalorização 
econômica e social, tais como os baixos níveis de remuneração, se comparados aos de outros profissionais com formação equivalente, e a baixa atratividade da carreira entre os jovens. Também compõe essa trama o Estado, que normatiza a relação dos servidores com a imprensa e cuja burocracia intermediária define regras que pautam a relação de professores, diretores e demais funcionários no cotidiano escolar. Aqui serão detalhados os mecanismos legais e administrativos que operam direta ou indiretamente para o tolhimento da fala pública dos docentes.

O terceiro capítulo, "A Subjetivação do Silêncio - Uma Construção Social", busca investigar o processo de incorporação da realidade descrita no capítulo anterior, ou seja, compreender em que medida as críticas e representações negativas atribuídas aos professores são assimiladas pelos mesmos na formação de suas identidades/subjetividades e se constituem como disposições de cultura. Essa análise se inscreve na discussão teórica sobre o processo de construção social da realidade e a participação dos agentes nesse processo; apoiamo-nos no campo de estudos das teorias de socialização contemporâneas e notadamente em autores como Peter Berger e Thomas Luckmann, Norbert Elias, Pierre Bourdieu, Bernard Lahire, Ervin Goffman e Claude Dubar. Deste último, apropriamo-nos também da análise sobre a construção das identidades profissionais em um contexto que o autor denomina de "crise das identidades".

Esse processo foi captado a partir da análise do material oral coletado em entrevistas semiestruturadas com dez professores da rede estadual de ensino de São Paulo. Os entrevistados foram escolhidos segundo método "bola de neve", em que os primeiros informantes indicam outros para compor a amostra. Observamos, nas indicações, a necessidade de abarcar a diversidade do professorado paulista (com critérios como tempo de magistério, região em que atua, formação inicial e participação em entidades representativas da categoria), mas não houve classificação a priori dos componentes presentes no grupo.

A realização de entrevistas semiestruturadas, seguindo a proposta metodológica da entrevista compreensiva (KAUFMANN, 1996), é opção desta pesquisa pela impossibilidade de observação do fenômeno, que é difuso; além de ser um instrumento ideal para a análise de subjetividades: 
No momento em que a percepção social transita pela consciência individual, ela passa por uma triagem, é modelada e reelaborada, segundo os valores do entrevistado (subjetividade), reinscrevendo-se, ao mesmo tempo, no social em virtude da situação de interação com o pesquisador e da experiência empírica do rememorar. A mobilização da subjetividade na construção das representações sociais, portanto, não se opõe à "objetividade" ou à "realidade", mas é um momento de construção da realidade; as práticas sociais estão permanentemente conectadas e impregnadas pelas representações, donde a sua importância no estudo das práticas sociais. (BRANDÃO, 2002, p. 41)

O cruzamento do material narrativo fornecido pelas entrevistas com "dados estatísticos e com aspectos macrossociais adquire um papel relevante, oferecendo elementos complementares de validação" (BRANDÃO, 2002, p. 42). Um roteiro básico (disponível em Anexo) foi construído com o objetivo de apreender, por meio da fala dos entrevistados, representações, percepções e imagens dos professores acerca de sua profissão e de sua presença no debate educacional. A grade de entrevista foi estruturada em categorias como "dados pessoais e socioeconômicos"; "escolha da profissão e formação"; "trabalho"; "lazer e tempo livre"; "atuação política" e "relação com a mídia e participação em debates". A abordagem dessas diferentes dimensões da vida de cada entrevistado era necessária para que fosse possível, na análise do material verbal coletado, captar a importância dos diferentes universos de socialização (família, formação escolar e acadêmica, trabalho) e revelar indícios que permitam reconstituir disposições e suas variações em diferentes contextos - tanto na dimensão diacrônica (duração de uma biografia), quanto na dimensão sincrônica (em domínios e contextos distintos). Isso porque uma disposição, tal como propõe Lahire (2004, p. 27),

é uma realidade reconstruída que, como tal, nunca é observada diretamente. Portanto, falar de disposição pressupõe a realização de um trabalho interpretativo para dar conta de comportamentos, práticas, opiniões, etc. Trata-se de fazer aparecer o ou os princípios que geraram a aparente diversidade das práticas. Ao mesmo tempo, essas práticas são constituídas como tantos outros indicadores da disposição.

Por fim, descrever o silêncio como um processo amplo e quiçá generalizado requer certa abstração dos milhares de indivíduos que dele participam e que o 
constroem. Por isso, mesmo que o silêncio seja tratado como disposição e/ou predisposição incorporada pelos indivíduos, é preciso considerar que tais disposições podem se atualizar em função de diferentes contextos e experiências socializadoras diversas. 


\title{
Capítulo 1 \\ OS CONTORNOS DO SILÊNCIO
}

\begin{abstract}
Quando é verdadeira, quando nasce da necessidade de dizer, a voz humana não encontra quem a detenha. Se lhe negam a boca, ela fala pelas mãos, ou pelos olhos, ou pelos poros, ou por onde for. Porque todos, todos, temos algo a dizer aos outros, alguma coisa, alguma palavra que merece ser celebrada ou perdoada.
\end{abstract}

Eduardo Galeano, Livro dos Abraços.

O silêncio dos professores, tomado como objeto desta pesquisa, tem como ponto de partida a constatação da ausência da voz dos docentes como fonte de informação no jornalismo educacional. No entanto, conforme exposto na introdução deste trabalho, não se limita a esse fenômeno: pretende-se mostrar como o ato de silenciar é, ao mesmo tempo, um constrangimento do meio e uma disposição incorporada e assumida pelos indivíduos desse grupo - uma construção social. O termo silêncio, portanto, não se refere aqui apenas a essa invisibilidade, mas ao quadro em que, silenciosos e silenciados, os professores deixam de emitir opiniões acerca da realidade educacional, mesmo quando convidados a fazê-lo.

Para o desenvolvimento desse argumento, será necessário definir com mais precisão os contornos desse silêncio - ou seja, caracterizá-lo. Neste capítulo, serão explicitados os elementos que levaram à identificação desse problema de pesquisa e à construção de seu objeto. Em primeiro lugar, serão destacadas as análises que fizeram a constatação da ausência, por um lado, e investigaram as imagens dos professores na mídia, por outro. Em seguida, serão expostos alguns dados que reforçam a existência do problema: depoimentos documentados de jornalistas que relatam dificuldades em entrevistar professores, dentre outros dados.

O silêncio dos professores, embora não tenha sido até aqui objeto central de pesquisas acadêmicas, foi constatado de diferentes maneiras por estudos que se dedicaram a analisar as imagens do professor na cobertura educacional. Duas 
organizações não governamentais (ONGs) fizeram, na última década, essa análise de maneira mais sistemática: a Agência de Notícias pelo Direito da Infância (ANDI) e a Ação Educativa. Esta criou, em 2002, um "Observatório da Educação"7, com o objetivo de "produzir informações consistentes e plurais para subsidiar a atuação da sociedade civil na defesa do direito à educação, favorecendo sua capacidade de intervenção na definição e implantação de políticas educacionais" ${ }^{\prime 8}$. De acordo com a própria instituição, esta foi uma resposta à constatação de que "o debate público sobre educação, pautado e referenciado por governos, necessitava ser pluralizado".

Era preciso, então, pautar outros pontos de vista e de análise para as questões educacionais, dando voz a pesquisadores, organizações da sociedade civil e à comunidade escolar. Análise da ANDI (2005) realizada ao longo de 2004 com 5.362 textos jornalísticos publicados por 57 jornais brasileiros mostrava que os professores constituíam 5,9\% do total de atores consultados, mesmo percentual de alunos, o que foi considerado já um avanço com relação a estudos anteriores realizados pela mesma entidade. Mas, mesmo com essa abertura, havia pouco espaço para opiniões divergentes, já que apenas um terço das reportagens apresentavam mais de uma fonte.

Dez anos depois de criar seu Observatório para lidar com a baixa pluralização do debate educacional na mídia, a Ação Educativa avaliava mudanças positivas nesse cenário, constatando, no entanto, a persistência do problema com relação aos docentes:

7 Importa, para o desenvolvimento deste capítulo e a identificação do problema de pesquisa, relatar a experiência da pesquisadora e sua trajetória na área. Graduada em Jornalismo, trabalhou no Observatório da Educação da Ação Educativa de 2007 a 2012, tendo participado da pesquisa e redação das publicações aqui citadas e, nos últimos três anos, coordenado o Programa. Dessa forma, envolveu-se ativamente da Campanha "Fala Educador, Fala Educadora!", criando estratégias para o envolvimento dos professores e das professoras no debate educacional. Outro projeto da Ação Educativa, que coordenou de 2010 a 2012, a Rede Vozes da Educação, tratou do tema do envolvimento do professorado no debate educacional em uma perspectiva latino-americana. Também é um dado importante o fato de o Observatório da Educação ser referência para jornalistas, que procuram a ONG para obter dicas e fontes para suas reportagens. Dessa forma, a pesquisadora conviveu com os repórteres que cobrem educação; deparou com recusas de entrevistas da parte de professores para falar de questões sensíveis ou críticas à administração pública, mas também encontrou docentes inclinados a relatar projetos pedagógicos bem-sucedidos; teve declinados convites que fez a professores para exporem, como debatedores, seus pontos de vista a respeito de políticas educacionais da conjuntura - ou, quando o convite era aceito, viu alegarem a necessidade de obter autorização de diretores de escola ou de órgãos regionais (em casos de municípios menores, inclusive com o argumento de que o Secretário de Educação deveria autorizar por escrito sua exposição); e ouviu dos colegas de profissão relatos sobre as dificuldades de coletar opiniões de professores em suas reportagens. É a partir desse trabalho cotidiano que surgiram os problemas de pesquisa e é com ele que foi estruturado o olhar para o tema, a formulação de hipóteses e questões de entrevista.

8 Texto retirado do Plano Trienal 2013-2015 da Ação Educativa, p.46. Disponível em: <http://www.acaoeducativa.org/portal/images/stories/pdfs/plano_trienal_2013_2015.pdf.>. Último acesso: 4 fev. 2014. 
Outras vozes surgiram e se fortaleceram no debate público: o campo acadêmico, cuja produção passou a ser mais considerada e abordada no noticiário educacional; e o empresariado, que criou articulações e promoveu campanhas buscando, ativamente, pautar na mídia as posições do setor sobre a educação (sobretudo em sua interface com o trabalho e o desenvolvimento). A cobertura sobre educação básica e pública se intensificou. Além disso, outros temas ignorados pela cobertura da grande imprensa passaram a ser considerados no debate educacional: as discussões sobre o financiamento da educação e o planejamento das políticas educacionais (Plano Nacional de Educação) são dois exemplos, entre outros [...] No entanto, ainda que a frequência do tema "educação" tenha consideravelmente aumentado e que a configuração do debate tenha apresentado mudanças nos últimos anos, permanecem desafios importantes relacionados à expressão das posições de estudantes e educadore/as e a afirmação do concepção de educação como direito humano. ${ }^{9}$

Assim como as análises das duas organizações, as pesquisas do campo acadêmico também constataram essa ausência. O corpus da pesquisa de Ferreira (2012) abrangia reportagens que tratavam da questão docente de maneira central, em que o tema já estivesse explicitado no título ou no primeiro parágrafo do texto. Mesmo com esse filtro, que poderia privilegiar a voz docente, constatou que "o professor da educação básica não aparece como fonte privilegiada para comentar sua própria condição" (FERREIRA, 2012, p. 22). Ao produzir uma reportagem sobre o professor, os jornalistas consultam em primeiro lugar os pesquisadores vinculados às universidades. Também são privilegiadas as chamadas "fontes oficiais" e outros atores privados, tais como o "Movimento Todos pela Educação" que, segundo Ferreira, têm recebido espaço significativo.

A pesquisadora considera como “fontes 'especialistas' apenas aqueles profissionais de instituições que foram consultados para opinar sobre os dados apresentados pelos jornais" (FERREIRA, 2012, p. 107). Dessa maneira, foram descartadas de sua análise as "fontes utilizadas para acrescentar dados às informações prestadas pelo texto jornalístico ou ainda as fontes que são usadas para expressar uma posição explicitamente contrária àquela que é posta no texto, o que no jornalismo costuma-se chamar de 'o outro lado da notícia'” (FERREIRA, 2012, p. 108).

9 Ibidem, p. 46-47. 
O fato é que, exceto quando o tema retratado são as questões relacionadas à própria categoria, o professor não é consultado sobre seu fazer pedagógico, como "fonte" ou autoridade no assunto - assim como médicos são consultados sobre temas relacionados à saúde e ao bem-estar, independentemente de serem pesquisadores ou representantes de órgãos de classe da categoria. Miguel Arroyo observa essa ausência na apresentação de seu livro Ofício de Mestre, que estava sendo escrito no momento em que o Estatuto da Criança e do Adolescente (ECA) completava dez anos. "No rádio e na TV, comentários de juristas, de assistentes sociais, de psicólogos e políticos sobre o 'Estatuto da Criança e do Adolescente'. E nós, educadores pedagogos, o que temos a dizer? Ninguém nos pede opinião? Qual a nossa opinião se com eles convivemos todo dia, se somos seus pedagogos?" (ARROYO, 2002, p.15).

Nesse ponto, é preciso fazer uma distinção no tratamento dado para os professores de universidades e para aqueles ligados ao ensino básico, também captada por estudos anteriores. "Enquanto os primeiros são valorizados em sua individualidade, possuem voz e nome, os segundos, por sua vez, aparecem frequentemente sem nome, ligados à rede pública, salientando 'pontos de sua formação que não são satisfatórios'” (BARBARA; BEBER-SARDINHA, 2004, p. 125 apud FERREIRA, 2012, p. 43-44). "O que se nota, portanto, como observam os pesquisadores, é a valorização dos professores pesquisadores da educação superior e o reforço do desprestígio da profissão docente enquanto categoria da educação básica” (FERREIRA, 2012, p.44).

Ao realizar uma revisão bibliográfica dos estudos que se dedicaram a analisar a imagem do professor da educação básica na mídia, Ferreira (2012) constatou que esta tem sido associada a um sentido pejorativo nos discursos jornalísticos em seus variados suportes, e que os modos de trabalhos e saberes dessa categoria profissional são "constantemente desqualificados e, muitas vezes, associados como causa da má qualidade da educação brasileira" (FERREIRA, 2012, p.42).

O professor criticado na imprensa é o professor "genérico", sua figura e papel social. Não são nomeados, não há especificação deste ou daquele tipo de professor que está sendo criticado - as acusações são atribuídas, muitas vezes (ou na maioria das vezes) a toda a categoria. Ilustra essa situação o trecho do artigo de um articulista do jornal Folha de S. Paulo, sobre a distribuição de um livro didático por meio do Programa Nacional do Livro Didático - PNLD. A obra foi apontada como controversa 
pela mídia por utilizar as variantes populares da língua portuguesa como estratégia para aproximar estudantes da Educação de Jovens e Adultos (EJA) da norma culta do idioma $^{10}$.

\begin{abstract}
Não pode, não, está errado, é ignorância, pura ignorância, má formação educacional, preguiça do educador em corrigir erros [...] Em tese, os professores são pagos - mal pagos, é verdade - para ensinar o certo. Mas, se aceitam o errado, como agora avaliza o MEC, o baixo salário está justificado. O professor perde a razão de reclamar porque não está cumprindo o seu papel, não está trabalhando direito e quem não trabalha direito não merece boa paga [...] Que professores prefiram a preguiça ao ensino, já é péssimo. Que o MEC os premie, é crime. $^{11}$
\end{abstract}

Tal desqualificação não se resume à ausência da voz docente como fonte e ao tratamento negativo à sua imagem. A situação se configura em uma verdadeira “exclusão" ou "segregação" dos professores, uma vez que o sentido que prevalece na cobertura, conforme conclui Ferreira, é o de "convocar 'melhores' profissionais para o cargo docente" (2012, p. 16). Assim, há uma "crescente proposição de exclusão dos professores e substituição desses profissionais por outros melhores como saída para os problemas da educação" (2012, p. 171).

Com o mesmo objetivo de verificar as representações dos professores do ensino básico nos meios de comunicação, ainda em 2012, um grupo de pesquisa do campo da educomunicação estudou o tema a partir de vários dispositivos midiáticos, como o jornal, a televisão, o rádio, o cinema, a internet, a publicidade, e a revista. As análises constataram que a figura do professor, tratado como figura genérica, ganha "contornos discursivos modelares", que vão da caricatura ao desprestígio, das acusações de incompetência e de inapetência profissional, chegando mesmo a declarar o "fim de uma espécie" com o surgimento das novas tecnologias (CITELLI, 2012).

Assim, o grupo conclui que há "duas grandes categorias organizadoras das matrizes narrativas constituídas para, nos termos midiáticos, representar a figura do

10 Analiso o episódio com mais detalhes no artigo "Quando a mídia noticia o irreal", publicado no Le Monde Diplomatique, jul. 2011. Basicamente, uma frase descontextualizada ("Nós pega os peixe") foi apresentada como erro gramatical ensinado pelo livro "Por uma vida melhor", quando, na verdade, ilustrava conceitos básicos de linguística, mais especificamente, de que existem outras variantes da língua que não a norma culta, e que estas devem ser valorizadas na EJA.

11 ROSSI, Clóvis. Inguinorança. Folha de S. Paulo, São Paulo, p. A2, 15 mai. 2011. 
professor: a comprovação e a predicação" (CITELLI, 2012, p. 14-15). A representação "comprovadora", diz o estudo, naturaliza o real ou pretenso mundo por onde circulam profissionalmente os educadores. Nessa categoria estão identificados os pronunciamentos de editorialistas, especialistas em educação ou agentes públicos, que fazem diagnósticos ou apenas comentários de problemas factuais ocorridos com professores e professoras, muitas vezes em casos de violência sofrida por parte de alunos ou de ocorrências policiais no bairro; nesse registro, também se encontram observações negativas sobre a "falta de preparo" dos educadores diante das atuais demandas de ensino ou das dificuldades decorrentes do uso das novas tecnologias, além de comentários sobre faltas excessivas, greves etc. Por outro lado, em registro positivo, destacam-se experiências de sucesso pontuais alcançadas graças ao esforço e empenho de determinado professor, ou de como uma professora foi capaz de superar os obstáculos e inovar em sua matéria.

Quanto à representação predicativa, o objetivo é "propor políticas e alternativas para o sistema educativo voltadas, quase sempre, a promover termos como eficácia e eficiência". Nessa categoria, chamou a atenção dos pesquisadores o fato de o professor ser o "único produtor discursivo que não comparece":

impressiona como, nas manifestações sobre os professores que circulam nos media, faltam as vozes dos próprios ou de entidades a eles associadas, como os órgãos classistas. Aliás, estes, quando são invocados, tendem a ser deslegitimados e apresentados como sinônimos de um sindicalismo nostálgico e ultrapassado. (CITELLI, 2012, p. 16)

A análise da cobertura ${ }^{12}$ de uma greve que durou 34 dias no estado de São Paulo, em 2010, reforça essa constatação, revelando o predomínio da visão dos gestores. Entre as notas e reportagens analisadas, $70 \%$ citam apenas dois lados, ou seja, governo e/ou Secretaria de Educação, em contraposição ao Sindicato dos Professores do Ensino

12 "Fonte determinante na cobertura da greve", artigo de autoria da pesquisadora publicado em 6 jul. 2010 no Observatório da Imprensa, para a qual foram coletadas 83 menções ao tema, entre reportagens, notas, cartas de leitores e artigos de opinião. Os diários analisados foram Folha de S. Paulo, Valor Econômico, Estado de S. Paulo, Jornal da Tarde, DCI, Jornal da Cidade de Bauru e A Cidade (Ribeirão Preto). Pode ser consultado em: <www.observatoriodaimprensa.com.br/news/view/fonte_determinante_na_cobertura_da_greve>. Última consulta em: 20 nov. 2012. 
Oficial do Estado de São Paulo - Apeoesp (embora outros sindicatos paulistas apoiassem a mobilização, somente a Apeoesp foi consultada). Nos $30 \%$ restantes se encontram notas sem declarações, entrevistas pingue-pongue ou reportagens que ouviram exclusivamente o poder executivo. Suas reivindicações, que tratavam de melhoria das condições de trabalho, realização de concursos públicos para os professores temporários e considerações sobre a maneira como se implantou um modelo de bonificação por mérito, aparecem vagamente como "questões salariais". Somente $15 \%$ das reportagens ouviram professores que não atuavam nos sindicatos para falar sobre a greve.

As pesquisas e análises produzidas no campo da comunicação e dos estudos do jornalismo indicam, portanto, que a mídia possui mecanismos de exclusão dos professores e que exerce papel importante ao reforçar imagens e representações negativas de seu papel - tópico que merecerá aprofundamento no Capítulo 2. No entanto, a presente pesquisa assume que as causas do problema extrapolam esse campo, pois identifica vários outros fatores que participam do fenômeno. Se restringíssemos a análise do silêncio aos limites impostos pelo campo midiático, ignoraríamos o fato de que, mesmo se tentarem entrevistar professores e funcionários de escola, os jornalistas também encontram entraves e recusas. Prova disso pode ser observada durante a mesma greve citada acima, por exemplo. Na época, a Diretoria de Ensino Leste 3 em São Paulo divulgou memorando orientando os gestores das escolas a recusar entrevistas:

\section{Prezados Diretores,}

Agradecemos a preciosa atenção em relação aos informes sobre os números de professores que estão aderindo à greve. Entretanto, em virtude dessa paralisação, a imprensa está entrando em contato diretamente com as escolas solicitando dados e entrevistas. Solicitamos ao Diretor de Escola para não atender a esta solicitação. ${ }^{13}$

Além das restrições burocráticas, jornalistas indicam o fato de que os educadores "não podem" falar com a imprensa sem a autorização das autoridades governamentais -

13 "Câmara municipal de São Paulo aprova fim da lei da mordaça", publicada pelo Observatório da Educação em 19 mar. 2010. A assessoria de imprensa da Secretaria Estadual de Educação (SEE-SP) confirmou a autenticidade do e-mail ao Observatório, mas disse que a iniciativa partiu da Diretoria de Ensino. Disponível em: <http://tinyurl.com/a85xol9>. Última consulta em: 20 nov. 2012. 
percepção que, conforme será abordado mais adiante, foi reiterada por professores nas entrevistas realizadas no âmbito desta pesquisa. Muitas vezes, ao negarem a concessão de entrevistas, os docentes alegam aos jornalistas a existência de normas que proíbem servidores de emitirem opiniões relacionadas ao exercício de sua profissão.

Em 2007, uma oficina organizada pela ONG Ação Educativa reuniu professores e profissionais de comunicação social para compreender os motivos da ausência da voz do professorado constatada na análise de reportagens sobre educação - atividade que resultou em diversos desdobramentos até a constituição da campanha "Fala Educador, Fala Educadora!”, em prol da liberdade de expressão dos docentes. O processo está registrado no "Dossiê o Silêncio do Professorado: Restrições Ilegítimas à Liberdade de Expressão dos Profissionais da Educação" (AÇÃO EDUCATIVA, 2008) e na publicação "Desafios da Conjuntura: O Silêncio do Professorado na Educação" (AÇÃO EDUCATIVA, 2007b). A norma que os docentes e jornalistas costumavam evocar para justificar a proibição de entrevistas foi identificada em um artigo do Estatuto dos Funcionários Públicos do Estado de São Paulo ${ }^{14}$ :

Art. 242 - Ao funcionário é proibido:

I - referir-se depreciativamente, em informação, parecer ou despacho, ou pela imprensa, ou qualquer meio de divulgação, às autoridades constituídas e aos atos da Administração, podendo, porém, em trabalho devidamente assinado, apreciá-los sob o aspecto doutrinário e da organização e eficiência do serviço;

$(\ldots)$

VI - promover manifestações de apreço ou desapreço dentro da repartição, ou tornar-se solidário com elas

Esse mesmo dispositivo foi encontrado pela entidade, com poucas variações, em ao menos 18 estados e em diversas capitais brasileiras ${ }^{15}$. Alguns deles - é o caso do município (1978) e do estado (1968) de São Paulo - datam do período da ditadura

14 Lei Estadual no 10.261, de 28/10/1968. Estatuto dos Funcionários Públicos Civis do Estado. O inciso I foi revogado pela Lei Complementar $n^{\circ} 1.096$, de 24/09/2009. O inciso VI segue vigente.

15 O levantamento está registrado no artigo "Servidores calados em todo país", de autoria da pesquisadora, publicado no Observatório da Imprensa em 26 fev. 2008. Disponível em: <http://www.observatoriodaimprensa.com.br/news/view/servidores_publicos_calados_em_todo_o_pai s>. Último acesso em: 4 fev. 2013. 
militar (1964-1985), e não poderiam ser considerados vigentes por afrontar o princípio constitucional da liberdade de expressão. Em outros casos - Amapá (1993), Espírito Santo, Rio Grande do Sul, Bahia, Maranhão, Mato Grosso do Sul, Pará (1994) e Paraíba (2003) - o estatuto foi promulgado após a Constituição, o que faz desse dispositivo uma norma inconstitucional. A referência mais antiga foi encontrada no estatuto federal dos servidores públicos (Lei n ${ }^{\circ} 1.711 / 52$, hoje revogada), promulgado durante o governo de Getúlio Vargas em 1952.

A existência dessas proibições foi depreendida a partir de depoimentos de jornalistas colhidos pela instituição, à época:

Nas reportagens de Educação, sobretudo as que envolvem debate de políticas públicas e gestão escolar, denúncias e discussões sobre a formação, encontro dificuldades para falar com professores e tê-los como fonte. Em geral, percebo que o educador se sente intimidado pelo sistema de ensino e prefere se ausentar do papel público de agente do processo educativo. Quando aceita se pronunciar, em praticamente $100 \%$ dos casos, o professor pede para que sua identidade permaneça em sigilo, temendo represálias de diretores, coordenadores e supervisores.

Gustavo Heidrich Oliveira, repórter da revista Nova Escola, Editora Abril.

Eu trouxe aqui uma quantidade muito grande de e-mails que nós recebemos, muitos de professores indignados, que são dedicados, que trabalham corretamente; e esses professores dizem que não foram ouvidos e que não puderam ouvir sua situação dentro das escolas. Eu queria dizer que nós aqui, a Rede Globo, tentamos várias vezes gravar entrevista com professores da rede estadual. Mas o Estatuto dos Servidores Públicos do Estado, que é de 1968, portanto, da época da ditadura, proíbe que eles se manifestem pela imprensa sobre seus superiores e também sobre os atos da administração. Ou seja, na prática, a lei proíbe que os professores deem entrevistas falando das más condições de trabalho.

Carla Vilhena, apresentadora do telejornal SPTV $1^{\text {a }}$ edição, TV Globo. Trecho de declaração feita ao vivo, no programa exibido no dia 14/12/2007.

Eu sinto que a classe, a categoria tem medo de falar. Às vezes a matéria é até positiva, "ai, não, não, você é jornalista não, por lei, não posso falar". Então, eu adotei um canal aberto com a Secretaria e eles me autorizam. Mas às vezes tem um impedimento porque tem pauta 
que é investigativa e você teria que investigar antes até para ver se a pauta renderia. E é muito complicado. Por isso que a gente se apoia nos depoimentos em off. Muitos professores querem fazer algumas denúncias, mas não têm coragem de falar. Os poucos que têm coragem são muitos corajosos e falam abertamente. Mas a pluralidade de fontes fica limitada. A Secretaria autoriza, nunca tive uma autorização negada, mas o professor sozinho tem muito medo.

Maria Rehder, repórter do Jornal da Tarde. Declaração feita no vídeo "Fala Mestre! Fala Mestra!", produzido por Ação Educativa, Artigo 19 e Save the Children UK.

Em setembro de 2007, entrei em contato com uma professora da rede estadual que trabalha na zona leste, região de Guaianases e Lajeado. Eu tinha necessidade de repercutir uma pauta específica sobre os resultados de uma avaliação educacional e liguei para a professora da zona leste para saber a opinião dela sobre o assunto. Seguiu-se um diálogo semelhante ao descrito aqui:

(Fiz uma introdução do tema e perguntei a opinião dela...)

(Professora) - Estou sentindo que você quer saber minha opinião sobre isso...

(Repórter)- Claro, professora. Liguei para saber o que a senhora acha desses resultados, como estou fazendo com outras pessoas. Não é só a sua opinião que está sendo ouvida. É uma repercussão, assim que chamamos.

(Professora) - Ah, mas não posso falar.... Estava percebendo que você queria a minha opinião...

(Falamos um pouco sobre o que conversamos durante uma atividade de formação, onde nos conhecemos no mês anterior)

(Repórter) - E como está o projeto de diagnóstico de violência que a senhora havia comentado? É possível conhecer os dados?

(Professora) - Acho que não. A gente não vai revelar os dados... Se você quiser falar de um projeto bom que a escola está fazendo agora...

(Repórter) - Podemos falar sobre esse projeto em outra oportunidade... Mas estou percebendo que a senhora está ressabiada com essa conversa, fique tranquila. Não vou escrever o seu nome no jornal. Estou ligando porque acreditei que pudesse falar sobre o assunto, mesmo que em off. Mas, se preferir, posso não ligar mais.

(Professora) - Prefiro assim.

(Repórter) - Olha, professora, então vou reverter a mão de direção da relação. Vou deixar meus telefones com a senhora. Quando quiser que o jornal a procure para falar de algum projeto que julgue interessante, por favor, entre em contato. Temos todo o interesse de falar com a escola e com vocês, professores, sobre os mais variados assuntos.

Nunca mais voltei a falar com a professora. Nem mesmo o projeto de 
destaque da escola, que ela havia citado durante a conversa, chegou ao meu conhecimento.

Fábio Mazzitelli, repórter do Diário de S.Paulo.

Mas, apesar da boa impressão, diretores, funcionários e alunos são orientados a não falar. Depois de alguma insistência, a subeditora de uma das escolas recebe o repórter em sua sala. Após breve explicação sobre o assunto da reportagem, de cabeça erguida e olhos nos olhos, é direta:

- O que você quer comigo exatamente?

- Uma entrevista sobre...

- Não Falo. Mais alguma coisa?

- Então queria só conversar informalmente, pode ser?

- Não pode ser. Mais alguma coisa?

(...)

O secretário de uma das escolas, ao ser abordado, explica com sinceridade:

- Olha, se você vier aqui dizendo que é jornalista, não vai conseguir nada. Fala que é estudante de sociologia e está fazendo um trabalho... Melhor ainda, fala que é de uma ONG e está pesquisando... Se falar que é jornalista, as portas vão se fechar na hora.

- Há orientação para não falar?

- Meu filho, todo mundo morre de medo de falar, ainda mais em ano eleitoral. Eu mesmo estou para ser efetivado e não quero encrenca para o meu lado. Não põe meu nome aí, não.

- Certo, não ponho. Mas qual é a sua opinião sobre o ensino noturno?

- O ensino noturno? É um lixo, horrível. O governo diz que está todo mundo na escola, né? Tudo maquiado. (...)

A diretora de outra escola recebe a reportagem em sua sala: "Olha, não adianta, nada do que você falar vai adiantar. Nem eu nem ninguém aqui vamos dar entrevista. Se você quiser, vá lá fora tentar falar com alguém. Aqui eu não vou permitir. A dirigente regional de ensino de Interlagos proibiu a gente de falar com jornalistas. Todo mundo aqui sabe disso. Com uma autorização dela, falo com o maior prazer. Mas já adianto que ela não vai autorizar."

O professor de história Cláudio Raimundo leciona na Gaivotas II desde que foi inaugurada, em 2000. Sindicalista, ele fala. Diz que, além do veto da direção regional a entrevistas, o pessoal do bairro é hostil com forasteiros por causa da violência, uma rotina local.

Trecho da reportagem Uma Noite em Escola de Lata, publicada na Revista Educação, em junho de 2006. 
Mais recentemente, um repórter do jornal O Estado de S. Paulo teve negada entrevista de uma professora e publicou reportagem ${ }^{16}$ sobre o tema:

Medo. A decisão pelo silêncio não é só na hora de criticar. Há alguns meses, o Estado procurou uma professora que havia confessado à reportagem que se sentia mais realizada ao dar aulas em escola pública na periferia do que em unidades particulares. No primeiro contato, empolgação sobre a oportunidade de falar sobre o assunto. Mas, em seguida, a frustração. "Conversei com os colegas e me disseram que não posso falar sem autorização, prefiro não prejudicar minha carreira", disse. E não houve argumento que a fez mudar de ideia.

Tanto ANDI como a Ação Educativa buscaram meios de incidir sobre essa realidade. Ao lado de entidades como a Confederação Nacional dos Trabalhadores em Educação - CNTE, a APEOESP e a ONG Artigo 19, que atua em defesa da liberdade de expressão, a Ação Educativa entregou o dossiê sobre o caso ao Relator da Organização das Nações Unidas (ONU) pelo Direito Humano à Educação, à Assembleia Legislativa e ao Procurador Geral do Estado de São Paulo, apresentando junto com o documento cópia de um abaixo-assinado com 1.015 assinaturas demonstrando apoio à iniciativa, tendo entre os signatários juristas, vereadores, deputados, jornalistas, pesquisadores, profissionais da educação, e representantes de organizações da sociedade civil. (AÇÃO EDUCATIVA, 2008, p.10). Durante a coleta de assinaturas, a instituição relata que enfrentou dificuldades para obter adesão dos professores:

Percebemos que os professores têm tanto receio de represálias a posicionamentos públicos, que alguns se recusaram a assinar o abaixoassinado que circulou em São Paulo pedindo a revogação da lei do silêncio, alegando que sua condição de funcionários públicos os impedia de subscrever "esse tipo de coisa". (AÇÃO EDUCATIVA,

16 O Estado de S. Paulo. "Opinião do professor é nula no debate sobre educação", de Paulo Saldaña. 21 abr. 2013. O jornalista procurou a pesquisadora, enquanto editora do Observatório da Educação da ONG Ação Educativa, para tratar do assunto. Afirmou que a pauta - a recusa de professores em dar entrevistas - motivou a realização dessa reportagem. Ao tomar conhecimento sobre o tema desta pesquisa, ainda em desenvolvimento, decidiu que esse seria o foco de seu texto. 
Em 5 de abril de 2010, ao lado das instituições parceiras na Campanha, a organização ingressou como Amicus Curiae em uma Arguição de Descumprimento de Preceito Fundamental (ADPF) no Supremo Tribunal Federal. A ADPF fora proposta pelo Partido Socialismo e Liberdade (PSOL), contra os dispositivos considerados contrários à liberdade de expressão no Estatuto dos Funcionários Públicos do Estado e do Município de São Paulo. O objetivo da petição era provar que, apesar das alegações de que tais dispositivos não estariam mais vigentes, eles seguiam sendo utilizados para intimidar os servidores públicos:

[com esta petição, as instituições signatárias] esperam acrescentar importantes elementos no sentido de demonstrar a não-recepção dos dispositivos questionados pela Constituição Federal de 1988. Também demonstrarão que, apesar de frontalmente contrários às liberdades democráticas e ao direito à informação pública, tais dispositivos seguem vigentes e efetivos na punição a servidores públicos, o que acaba por estabelecer um verdadeiro mecanismo de censura prévia. ${ }^{17}$ (p. 4)

Além desse efeito "difuso" da lei, argumento reforçado por depoimentos de jornalistas e professores, a petição levou a conhecimento do STF casos de aplicação de processos administrativo-disciplinares que tiveram como base o dispositivo questionado:

Em um levantamento com fins meramente amostrais realizado junto à base de informações da Imprensa Oficial do Estado de São Paulo, e que toma como referência unicamente os anos de 2003 a 2009, foram identificados 12 (doze) casos de punições a servidores públicos estaduais aplicadas com base nos dispositivos questionados nesta $\mathrm{ADPF}$ e que ainda se encontram em vigor. Em todos eles há referência ao inciso VI do art. 242 da Lei Estadual atacada, sendo que em um deles este dispositivo é aplicado cumulado ao inciso VII, do art. 243, da mesma norma.

17 Petição de Amici Curiae na Arguição de Descumprimento de Preceito Fundamental $\mathrm{n}^{\circ} 173$. Disponível em: <http://www.acaoeducativa.org.br/portal/images/stories/pdfs/2_amicusplm.pdf>. Último acesso: 4 fev. 2013. 
No âmbito municipal, o mesmo levantamento identificou 20 (vinte) casos de aplicação efetiva, nos últimos anos, do inciso I, do art. 179, da Lei Municipal n. 8.989/79. Em 11 (onze) dos casos identificados, trabalhadores da educação são punidos por infringência ao referido dispositivo.

Um caso exemplar nesse sentido foi vivenciado pela servidora Isis Longo, que exercia a função de diretora da Escola Municipal de Educação Infantil Profa. Maria Helena Barbosa (Anexo 6). Tal servidora sofreu procedimento de apuração preliminar $\left(\mathrm{n}^{\circ} 2006-\right.$ 0.054.405-9) por haver concedido entrevista à rádio $\mathrm{CBN}$, em 21/02/2009, e ao jornal "O Estado de S. Paulo", em matéria intitulada "Diretora de Escola aponta falha em obra", publicada em 22/02/2006. Em tais matérias, a servidora reclamava da omissão da administração central em apurar irregularidades em obras realizadas na escola sob sua gestão.

Segundo relatório assinado pela Chefe de Gabinete da Secretaria Municipal de Educação, em 06 de junho de 2006: "Resta comprovado (...) que a Senhora Diretora Isis Sousa Longo foi informada e comunicada oficialmente sobre a não permissão de concessão de entrevistas, bem como foi esclarecida de que se encontrava em estágio probatório (...) A Comissão de Apuração Preliminar entendeu que a Senhora Diretora da U.E., Senhora Isis Longo desrespeitou a hierarquia, feriu a legislação ao conceder entrevistas a jornais e rádio, não acatou orientações dos Órgãos superiores e não guardou sigilo dos assuntos da Administração, infringindo, portanto, os incisos II, III, IV, VIII, XI e XII do Artigo 178 e "caput" e inciso I do Artigo 179, ambos da Lei $8989 / 79 .{ }^{18}$

Em 24 de setembro de 2009, a Lei Complementar $n^{\circ}$ 1.096/2009 revogou expressamente o inciso I do art. 242 da Lei Estadual n. 10.261/1968 (trecho que trata da proibição de "referir-se depreciativamente"), mas manteve outros trechos restritivos. No município, Lei $\mathrm{n}^{\mathrm{o}}$ 15.135, de 22 de março de 2010, também revogou o dispositivo.

Além da atuação na esfera judicial e política, as organizações procuraram intervir na cobertura midiática, buscando sensibilizar os profissionais da comunicação para o problema. Em 2009, o Observatório da Educação lançou uma categoria "profissionais da educação básica" em seu banco de fontes para jornalistas - com o objetivo, justamente, de auxiliar os repórteres na busca de docentes dispostos a falar com a imprensa, disponibilizando seus contatos particulares (e-mail, telefone fixo e 
celular) $^{19}$. Já em 2008, a ONG avaliava que a Campanha trouxe desdobramentos positivos:

nota-se que alguns jornalistas adotaram a prática de registrar em suas reportagens a dificuldade de ouvir professores, relatando quando pedem para não ser identificados, e o trâmite burocrático para chegar até a escola. Avaliamos ser este um importante indício de sensibilidade e, ao mesmo tempo, indignação em relação aos mecanismos restritivos à liberdade de expressão que atinge, de forma diferente, tanto professores quanto jornalistas. ${ }^{20}$

Citando o trabalho da Ação Educativa, a ANDI incluiu, em 2009, um verbete em seu guia de fontes, distribuído a jornalistas que cobrem educação:

Outra voz que com frequência fica de fora da pauta é a dos docentes. Nesse caso, em grande número de cidades e estados há um agravante contra o qual algumas organizações da sociedade civil têm lutado bravamente: as chamadas "leis da mordaça". Muitos professores ou diretores são proibidos - em função dos parâmetros legais que regulam as atividades dos servidores públicos - de expressar livremente suas opiniões para os jornalistas. Antes de fornecer qualquer depoimento para veículos de comunicação, esses profissionais precisam solicitar uma autorização às assessorias de imprensa. Mesmo quando autorizados a falar, ainda assim, correm o risco de ser punidos - caso a opinião emitida seja considerada depreciativa. Por essa razão, em muitas ocasiões, a única maneira de conseguir o depoimento de um profissional de educação é apelando ao recurso do off (ou seja, sua identidade não pode ser revelada publicamente). (ANDI, 2009, p. 88-89)

No mesmo guia, a Agência estimula os jornalistas a buscarem fontes plurais para suas reportagens, chamando atenção para a importância dos sindicatos e associações representativas dos docentes. Mas, ressalta, "ouvir os sindicatos também não esgota a necessidade de buscar professores e diretores. Às vezes, quando a reportagem trata de uma questão específica de uma escola, é fundamental ter a opinião de quem trabalha no local” (ANDI, 2009, p. 90).

Quase seis anos após o início da campanha e dos esforços das diversas entidades

19 "Observatório lança Banco de Fontes de profissionais da educação básica", publicada pelo Observatório da Educação em 19 ago. 2009. Disponível em <http://tinyurl.com/d4pf4eg>. Último acesso em: 20 fev. 2013.

20 Ação Educativa, Relatório de Atividades 2008, p. 35. Disponível em: <http://www.acaoeducativa.org.br/images/stories/pdfs/relatorio2008.pdf>. Último acesso: 4 fev. 2013. 
pela revogação das restrições legais em São Paulo, no entanto, a ideia de que aos professores da educação básica pública não é permitida a livre manifestação segue presente no imaginário da categoria, corroborando a hipótese traçada aqui de que os constrangimentos legais são elementos importantes, mas não suficientes para explicar o problema. Conforme trataremos no capítulo seguinte, a suposta proibição emergiu da fala de entrevistados no âmbito desta pesquisa, assim como o reconhecimento tácito de que os posicionamentos críticos poderão gerar represálias. Entretanto, antes de proceder a essa análise, convém avançarmos na definição do silêncio contrapondo-o a seu oposto - a palavra, ou, de forma mais ampla, a ação. Também se faz necessária a explanação do que entendemos por debate público e o papel dos meios de comunicação de massa nesse contexto.

Dedicando-se ao exame da sociedade brasileira e, em grande medida, latinoamericana, Paulo Freire identifica como consequência de um passado de colonização e de um presente de dominação certo "mutismo", o que levou o educador a cunhar o conceito de "cultura do silêncio" (LIMA, 2011). Para Freire, à estrutura de dominação presente na sociedade brasileira corresponde uma totalidade ou um conjunto de representações e comportamentos, ou "formas de ser, pensar e expressar", que são "tanto um reflexo como consequência da estrutura de dominação".

Também segundo Freire, a palavra é mais que um instrumento que torna possível o diálogo. Seus dois elementos constitutivos, reflexão e ação, estão em uma “interação tão profunda que se uma é sacrificada, ainda que em parte, a outra sofre imediatamente" (FREIRE, 1974, apud LIMA, 2011, p. 91). Um homem que "tem voz" é sujeito de suas próprias ações e projeta livremente seu destino. "Dizer a própria palavra não é um ato verdadeiro a menos que esteja simultaneamente associado ao direito de autoexpressão e de expressão do mundo, de criar e recriar, de decidir e escolher e, em última análise, de participar do processo histórico da sociedade" (FREIRE, 1976, apud LIMA, 2011, p. 92). Por isso, destaca, o mutismo não significa ausência de resposta, mas sim um tipo de resposta que carece de criticidade. A centralidade do discurso para o ser humano é afirmada em sua obra Pedagogia do Oprimido (2005, p. 90): "não é no silêncio que os homens se fazem, mas na palavra, no trabalho, na ação-reflexão". 
na reflexão que Hannah Arendt (2010) tece acerca da compreensão grega da política. Arendt destaca que, para os gregos, esses conceitos eram tidos como "iguais". Não somente porque a maioria das ações políticas eram realizadas por meio das palavras, mas fundamentalmente porque o próprio "ato de encontrar palavras certas no momento certo, independente da informação ou comunicação que transmitem, constitui uma ação" (ARENDT, 2010, p. 31). Sem o discurso, a ação perde a capacidade de "revelar" os sujeitos e estes seriam mais próximos de "robôs executores". A ação "muda", conclui Arendt, deixaria de ser ação (ARENDT, 2010, p.223).

No entanto, a plena realização do discurso, como forma de ação, só é possível no domínio público. É somente no domínio público onde pode haver reconhecimento e participação com os outros, para que a individualidade possa ser assim manifestada ${ }^{21}$. Se a ação e o discurso são as características distintivas dos homens, sua prática só é possível num âmbito de pluralidade (possibilidade de pensares, agires e sentires diferentes), que, por sua vez, só pode ser pensado em termos de uma dimensão pública. Arendt define o público como dois fenômenos correlatos: primeiro, significa que "tudo que aparece em público pode ser visto e ouvido por todos e tem a maior divulgação possível. Para nós, a aparência - aquilo que é visto e ouvido pelos outros e por nós mesmos - constitui a realidade" (ARENDT, 2010, p. 61). Segundo a autora, o termo também significa o próprio mundo, "na medida em que é comum a todos nós e diferente do lugar que privadamente possuímos nele" (p. 64).

Mas, num fenômeno característico do mundo moderno, as duas esferas - pública e privada - recobrem-se constantemente uma à outra. Há, cada vez mais, uma transferência de atividades para o âmbito social e a ação é substituída por "comportamento" como principal forma de relação humana.

Desde o advento da sociedade, desde a admissão das atividades domésticas e da administração do lar no domínio público, uma das principais características do novo domínio tem sido uma irresistível tendência a crescer a devorar os domínios mais antigos do político e do privado, bem como a esfera da intimidade, instituída mais recentemente. (ARENDT, 2010, p. 55)

${ }^{21}$ Hannah Arendt lembra que a democracia, no sentido grego, não significava universalidade. A existência de uma esfera privada, onde as necessidades eram satisfeitas, possibilitava a participação na Ágora - todos ali eram livres e iguais (uma minoria, portanto, ascendia à condição de cidadão). 
A possibilidade de fazer política fica, desse modo, comprometida. Com essa reflexão, Hannah Arendt auxilia-nos a considerar alguns desafios para a ação política e, portanto, a participação crítica no debate público - dos professores. Diante da definição de espaço público que desenvolvemos aqui, a participação no debate não é entendida apenas como a expressão nos meios de comunicação massivos. Trata-se também de pensar o envolvimento crítico no debate (no caso estudado aqui, sobre educação) como capacidade de reflexão e ação política do professor, caracterizada pela manifestação de convicções, de opiniões e posições em diferentes espaços de atuação.

O estudo das relações entre a comunicação massiva e os processos políticos democráticos, na tradição republicana, aponta como ethos adequado à experiência democrática aquele que permite a existência de cidadãos preocupados com a vida pública, com a formulação de questões e a resolução de problemas de sua comunidade política - tanto no nível micro, local, quanto no macro, do Estado. Politicamente ativos, os cidadãos são envolvidos em redes de interações sociais que acabam por formar "linhas de interlocução e/ou defesa" em face das corporações ou autoridades (GOMES; MAIA, 2011, p. 15).

No entanto, entre a definição teórica de uma esfera pública e suas diferentes formas materializadas nos distintos períodos históricos, há diversos "déficits democráticos". As mídias massivas, por exemplo, estão longe de cumprir seu papel com relação à formação de um ethos cívico e ao favorecimento da participação política. "Os agentes midiáticos podem tanto mobilizar questões políticas relevantes, as informações requeridas e as contribuições apropriadas para um debate público eficaz, quanto podem ignorar questões importantes, banalizar ou distorcer informações, deslegitimar a voz de certos atores, enquanto advogam em benefício de outros" (GOMES; MAIA, 2011, p. 22).

Além disso, a temporalidade e a linguagem dos meios de comunicação, cada vez mais, distanciam esses espaços das condições para um verdadeiro debate de ideias. Já não há lugar para "momentos de dúvidas, de requestionamentos, de estabelecimento de conexões pessoais entre 'representações' simbólicas, elaborações subjetivas" e a linguagem dominante é aquela "dos fatos, das decisões tomadas, das ações cometidas, e não a da argumentação, do discurso problemático" (DUBAR, 2009, p. 178). Dentre outras características verificadas nos meios de comunicação, ainda, podem ser citadas o 
excesso de personalização e a espetacularização do mundo. "A imagem impõe a personagem política em detrimento de sua eventual mensagem" (DUBAR, 2009, p. 179).

Nesse sentido, tudo leva a crer que as condições de possibilidade para a participação dos professores no debate público e a emergência de suas vozes estão diretamente relacionadas à valorização da profissão e à identidade profissional construída pelos docentes - bem como àquela que lhes é atribuída pela sociedade. A hipótese que buscamos verificar nesta pesquisa é a de que o silêncio dos professores, como construção social, é resultado de um amplo e contínuo processo de socialização em que se articulam múltiplos fatores, de ordem objetiva e subjetiva, da vida dos docentes. Visto sob essa perspectiva teórica, o silêncio é produto de uma configuração que, em seu atual equilíbrio de forças, é extremamente desfavorável aos professores; e que produz, entre outros fenômenos, uma série de disposições culturais da categoria que provocam seu afastamento do debate público sobre educação.

Apoiamo-nos no conceito de configuração de Norbert Elias (2006) para descrever de maneira mais precisa essa complexa trama de silenciamento em que os docentes estão enredados e ajudam a tecer. A noção de configuração - ou figuração, como Elias a tratava em seus primeiros escritos - aplica-se a formações sociais que os seres humanos integram uns com os outros, em pequenos ou grandes agrupamentos. É útil para considerar os indivíduos na dinâmica de seu convívio social, assim como suas interdependências e as instituições com as quais se relacionam. Dispomos, assim, de "uma imagem do ser humano e de um instrumento conceitual mais adequado à realidade" (ELIAS, 2006, p. 27), evitando o dilema da autonomia dos indivíduos frente à estrutura a que pertencem.

Isso posto, cumpre o exercício a que nos propusemos a seguir, buscando nas falas dos docentes entrevistados os fatores objetivos dessa configuração: os vários níveis de desvalorização pelos quais passa a docência hoje (social, econômica, simbólica); processos decorrentes das mudanças no mundo do trabalho, tais como sua precarização e intensificação; as representações que circulam no imaginário social a respeito dos professores, produzidas e reproduzidas na mídia; e a existência de mecanismos legais, administrativos e burocráticos que tolhem sua liberdade de expressão ou desencorajam sua fala pública. 


\title{
Capítulo 2
}

\section{Da Concretude do SiLÊNCIO}

\begin{abstract}
Há muito trem que não chega, muitos salários não recebidos, muita dignidade nas condições de trabalho adiada. As circunstâncias sociais nos fazem e desfazem. Mas também nós mesmos nos fazemos e nos desfazemos. Somos sujeitos de nossa história.
\end{abstract}

Miguel Arroyo, Ofício de Mestre: Imagens e Autoimagens.

De dez entrevistas semiestruturadas com oito professoras e dois professores da rede pública de São Paulo $^{22}$, emergiram múltiplos traços comuns que nos permitem reconstituir um quadro bastante "concreto", isto é, permitem apresentar os elementos objetivos do mundo social que ajudarão a explicar o processo de silenciamento ou suas variações menos visíveis como o recuo e a busca pela invisibilidade. Além desse material narrativo, buscou-se apoio em informações, dados, levantamentos e pesquisas que se dedicaram a analisar a condição docente e situam esses relatos em processos mais amplos.

Não se trata de proceder a uma análise aprofundada sobre cada um desses temas, mas sim estruturar um feixe de condicionamentos que, articulados, desenham uma configuração favorável para o silêncio. O procedimento metodológico de separar essa análise em dois tempos - os elementos objetivos (Cap. 2) e sua subjetivação (Cap. 3) se justifica pela organização do texto, mas não significa que essas duas dimensões sejam, de fato, apartadas. Pelo contrário, são imbricadas no mundo social, uma vez que este, como destaca Bourdieu, "é ao mesmo tempo produto e objeto de disputa de lutas simbólicas, inseparavelmente cognitivos e políticos, pelo conhecimento e pelo reconhecimento, nas quais cada um persegue [...] o poder de impor como legítimos os

22 As professoras entrevistadas e suas respectivas idades são: Nilce (43); Rosa (47); Cilene (31); Dalva (50); Sandra (31); Elaine (48); Maísa (48) e Cristina (45). Os professores são: João (25) e Alberto (48). Optou-se por alterar seus nomes, devido à abordagem de temas sensíveis ao cotidiano escolar e às suas vidas privadas, ainda que todos tenham gentilmente autorizado a publicação do conteúdo relatado. Mais detalhes sobre cada um deles são introduzidos na forma de perfis no capítulo 3. 
princípios de construção da realidade social mais favoráveis a seu ser social (individual e coletivo) ${ }^{, 23}$ (BOURDIEU, 1997, p. 270). Assim sendo, a todo momento, serão indicados os entrecruzamentos possíveis nessa configuração.

Conforme detalhado na introdução deste estudo, valemo-nos do método "bola de neve" para identificar os entrevistados, a partir de alguns professores indicados à pesquisadora em três regiões da cidade de São Paulo: zona norte e noroeste; zona oeste e zona sul. O único critério solicitado para indicação era que o professor atuasse na rede estadual de ensino - o recorte se justifica para permitir ao menos o cruzamento de dados desse universo. Chegou-se ao número de dez entrevistas a partir do momento em que as falas não propunham elementos novos; pelo contrário, o material narrativo coletado em regiões bastante distantes da cidade acabou apresentando uma série de recorrências discursivas.

No entanto, não foram poucas as dificuldades que se impuseram na busca e na realização dessas entrevistas. Em primeiro lugar, o contexto de sobrecarga e intensificação do trabalho, que será desenvolvido no presente capítulo, exigiu que as entrevistas fossem realizadas na própria escola, em horário de almoço ou durante horário dedicado ao trabalho pedagógico (Jornada Especial Integral de Formação - JEIF no município, Aula de Trabalho Pedagógico Coletivo - ATPC no estado). Nove das dez entrevistas só puderam ser viabilizadas dessa forma. Pelo mesmo motivo, outras tantas foram recusadas: falta de tempo. Também recusaram entrevistas professores que, reforçando o problema colocado por esta pesquisa, não acreditavam que poderiam contribuir ("não tenho nada para falar sobre isso", "não tenho argumentos") ou que simplesmente desmarcaram, sem motivo aparente. Ao todo, foram feitas 27 tentativas.

Embora o método utilizado não busque uma amostra representativa, este grupo, como se verá, é bastante significativo para o universo pesquisado. A partir das entrevistas, foi construído um quadro, considerando, para cada um dos entrevistados, aspectos pessoais, de trabalho, de formação, da sua relação com a mídia, de engajamento e ação política, seu ambiente escolar e suas "imagens do professor". O quadro foi assim desenhado para que fosse possível visualizar recorrências e

23 Do francês: "Le monde social est donc à la fois le produit et l'enjeu des luttes symboliques, inséparablement cognitives et politiques, pour la connaissance et la reconnaissance, dans lequellles chacun poursuit [...] le pouvoir d'imposer comme légitimes les principes de construction de la réalité sociale les plus favorables à son être social (individuel et collectif)". 
entrecruzamentos a partir do material narrativo coletado e transcrito, mas optou-se por estruturá-lo, no capítulo seguinte, em formato narrativo que evidencie tais interligações.

No Brasil, a primeira e mais flagrante característica desse grupo profissional é a de que sua maioria é composta de mulheres - cerca de $80 \%$ dos quase dois milhões de docentes da educação básica - e atua nas redes públicas de ensino (MEC/INEP, 2009). Assim como ocorre no grupo entrevistado, tendencialmente, as professoras provêm das camadas mais baixas das escalas de indicadores socioeconômicos e pertencem, fundamentalmente, a grupos que tentam a ascensão social pela instrução (GATTI, 2010). No estado de São Paulo, onde esta pesquisa está sendo desenvolvida, há cerca de 390 mil funções docentes nas diversas etapas e modalidades da educação básica - tanto na rede pública quanto particular de ensino - de acordo com dados da Sinopse do Professor (MEC/INEP, 2009). O número representa 20\% das funções docentes em todo o país - o percentual mais elevado entre todas as unidades da federação. São Paulo também possui o maior número de matrículas: mais de 9 milhões de alunos, de acordo com a mesma base de dados.

A abrangência do quadro que desenvolveremos a seguir é tão ampla quanto permitirem os dados coletados - alguns fenômenos do mundo da docência são globais, outros são específicos do caso brasileiro. No entanto, sempre que possível, traremos análises que tenham como base o estado de São Paulo, uma vez que os professores entrevistados nesta pesquisa pertencem a esse universo. Outro aspecto que procuramos introduzir em cada tópico é o ponto de vista processual e histórico, dimensões fundamentais para compreender o campo que nos propusemos a analisar. Antes de prosseguir, é preciso reconhecer que o grupo com que trabalhamos - os professores não é um todo homogêneo. A depender da região analisada, do nível socioeconômico, da formação ou mesmo dos níveis e modalidades de ensino consideradas, serão

significativas as variações. Apoiamo-nos em estudos para captar aquilo que é característica comum desse universo - sem perder de vista a importância de contextos, interações e realidades locais para a construção da identidade desse profissional.

\subsection{A Condição "Proletária" ou Intelectual do Trabalho Docente}

Quem é esse professor - aqui entendido como um papel social, o professor 
"genérico", idealizado - a quem, a todo momento, se evoca no debate público sobre educação? Como entender a retórica da urgência de valorização desse profissional se, ao defender isso, as diferentes vozes do debate público alçam-no à condição de herói, atribuindo-lhe funções que extrapolam sua profissão? Gatti (2010, p. 238-239) sintetiza:

Pode-se afirmar que as expectativas são altas, mas a valorização é baixa [...] No Brasil, as ênfases valorativas da profissão de professor no âmbito sociocomunitário variam muito conforme a região do país, porém os discursos genéricos existentes sobre o valor do professor não redundaram em todos os estados e em todos os municípios em estatutos de carreira, e em salários, que reflitam a importância retórica a esse profissional atribuída.

A defesa do reconhecimento de sua condição de profissional costuma estar associada à reivindicação de condições de trabalho, mas também de reconhecimento de sua autonomia, "como dignos de respeito e como especialistas em seu trabalho" (CONTRERAS, 2002, p. 54). Trata-se, portanto, de uma tensão entre a condição intelectual (e, portanto, mais associada ao conceito de "profissional") e a condição proletária (ou, mais identificada à categoria de "trabalhadores") do ofício docente ${ }^{24}$, que buscaremos desenvolver a seguir.

Para compreender a multiplicidade de representações que marcam a profissão na atualidade, é preciso ter presente, como o faz Miguel Arroyo (2002), que ela carrega uma longa memória. Antes sob a tutela da Igreja, a escola passa a ser estatizada a partir do século XVIII, e a docência começa então a ser constituída como atividade profissional. Ao lado da (ainda latente) imagem de missionário, do ser capaz de sacrifícios e vocacionado - características do corpo docente religioso - emerge uma imagem do professor profissional, que, sem abandonar o valor de sacerdócio, deve possuir "a humildade e a obediência devidas aos funcionários públicos" (NÓVOA, 1992). O Estado assume gradativamente a função de controlar a educação formal, seus conteúdos e regras, recrutando e formando profissionais para esse fim. No Brasil, esse

24 Para Arroyo (2002), o termo ofício não se contrapõe à noção de profissionalismo, pelo contrário: "remete a um fazer qualificado, profissional. Os ofícios se referem a um coletivo de trabalhadores qualificados, os mestres de um ofício que só eles sabem fazer, que lhes pertence, porque aprenderam seus segredos, seus saberes e suas artes" (p. 18). O pesquisador não deixa de reconhecer, no entanto, que há movimentos de expropriação do saber profissional dos professores por meio da organização parcelar do trabalho, o que, por sua vez, também gera resistências. 
processo é mais perceptível a partir de meados do século XIX, quando se ampliaram os dispositivos de normatização e controle da docência. Nesse período, foram criados cursos destinados à formação do magistério primário e produzidos impressos especializados, como manuais pedagógicos (VICENTINI; LUGLI, 2009).

A permanência de representações sociais da docência como "vocação" e "missão" no imaginário social - tópico que recebe análise mais detalhada, adiante - tem impacto na luta por melhores condições profissionais, porque implicam a perspectiva da “doação de si” (GATTI; BARRETO, 2009). Essas imagens impõem dificuldades, por exemplo, na reivindicação de melhores salários, mas também se constituem como elementos da cultura docente e são incorporadas pela categoria, penetrando em suas autoimagens, práticas e mentalidades.

Meu irmão diz "você reclama mas tem isso, tem aquilo". Eu digo: "eu tenho isso porque trabalho!" Três períodos, tenho que acumular cargos para ter o que eu quero ter [Nilce].

Para o aluno, principalmente adulto, ou adolescente que estuda à noite; para eles o professor trabalha pouco e ganha muito. Eles olham nos estacionamentos, mas ninguém olha o carnê que tá na bolsa para pagar aquele carro lá fora [Rosa].

Esse retrato do professor de... uma pessoa que está reivindicando algo que ele não tem direito, o professor que não tem preparo, o professor violento que trata mal [Cilene].

Você presta um concurso para Nível Superior, eu acho que, de qualquer... quase que qualquer concurso que você comparar, em Nível Superior, o professor é o que ganha menos, é o que é menos valorizado... quando faz greve é porque não quer trabalhar, é porque é preguiçoso [Sandra].

Oposto ao conceito de profissionalização, chama-se de proletarização o fenômeno caracterizado pela progressiva perda (ou o não reconhecimento) das qualidades que fazem dos docentes profissionais, sobretudo a autonomia, ou, ainda, pela precarização das condições de trabalho. Fazendo a ressalva de que não há unanimidade 
entre os autores que defendem a teoria, Contreras (2002, p. 33) define a tese básica da proletarização como a consideração de que "os docentes, enquanto categoria, sofreram ou estão sofrendo uma transformação, tanto nas características de suas condições de trabalho como nas tarefas que realizam, que os aproxima cada vez mais das condições e interesses da classe operária”. Algumas das características que conferem o estatuto de profissão à docência nunca chegaram a ser plenamente conquistadas para toda a categoria - sobretudo se considerarmos a totalidade da carreira, da educação infantil ao ensino superior - e alternam-se períodos de maior ou menor precarização do trabalho.

Um momento de tensionamento do estatuto profissional da docência pode ser observado, por exemplo, nas crescentes experiências de ensino em tempo integral nas escolas públicas, induzidas por programas federais e de outros entes federados. Somente no primeiro caso, segundo o Ministério da Educação, são quase 15 mil unidades escolares que aderiram ao Programa Mais Educação, em 2011 25 . A forma mais comum de implantação desse tipo de programa é a ampliação da jornada com atividades extracurriculares no chamado contraturno (período oposto ao das aulas regulares), sem que necessariamente se ofereçam às escolas condições de fixação e dedicação exclusiva dos docentes. São contratados, para dar conta da nova demanda, "oficineiros", educadores sociais ou estudantes, que muitas vezes desenvolvem atividades pedagógicas sem a exigência de qualificação profissional e/ou qualquer vínculo com a carreira docente. Se, por um lado, a ideia de educação integral (no tempo e na concepção) pode representar avanços e conquistas para a realidade da escola pública brasileira, por outro também pode abrir novas brechas para esse processo de desprofissionalização, de descaracterização dos profissionais do ensino - em contraste com os avanços que culminaram em 1996, com a nova Lei de Diretrizes e Bases da Educação (LDB), que exige a formação em nível superior de todos os profissionais da educação básica.

Foi no início da década de 1950 e durante os anos de 1960 que a categoria começou a se mobilizar em reivindicações coletivas mais amplas. Em São Paulo, o professorado realizou sua primeira greve em 1963 (VIANNA, 1999, p. 88). É o início

25 Programa criado pela Portaria Interministerial $n^{\circ}$ 17/2007 e regulamentado pelo Decreto Federal $n^{\circ}$ 7.083/10. De acordo com o site institucional do MEC (www.portal.mec.gov.br), o número de escolas que aderiram em 2011 é 1.495 (último acesso: 18/01/2014). Se a meta em discussão no próximo Plano Nacional de Educação - Projeto de Lei $n^{\circ}$ 8.735/2010 - for cumprida, serão 50\% das escolas do país oferecendo ensino integral em 2021. 
de um processo de identificação da luta dos professores com a de outros trabalhadores que ganha força nos anos de 1970, quando a categoria passa a adotar o termo "trabalhadores em educação". Em 1990, a CPB - Confederação dos Professores do Brasil articula-se a outras federações setoriais da educação e passa a se chamar CNTE Confederação Nacional dos Trabalhadores em Educação. Mais que uma estratégia para a luta por melhores condições de trabalho, essa identificação pode ser considerada como busca de maior reconhecimento social da categoria.

Poderíamos ver nesse gesto apenas uma estratégia de luta por salários, carreira, estabilidade, até uma justificativa para usar as mesmas formas de luta aprendidas pelo movimento operário, as greves, protestos, manifestações de rua. Poderíamos ver, ainda, nessa identidade de trabalhadores a procura de reforço das centrais sindicais. Podemos ver mais. Um aspecto a destacar poderia ser a percepção dos docentes da necessidade de incorporar um reconhecimento social, uma identidade coletiva que sempre lhes foi negada. (ARROYO, 2002, p. 190)

Não se pode afirmar, porém, que esse entendimento seja partilhado pelo professorado como um todo. Entre os professores entrevistados nesta pesquisa, por exemplo, apenas um [Dalva] fez referência à palavra "trabalhadores", para descrever a categoria. Mesmo entre os sindicalistas, outras pesquisas revelam uma variedade de posições quanto à identificação com a condição de trabalhadores em educação ou profissionais, categorias colocadas em oposição muitas vezes. Márcia Ondina Ferreira (2006) analisou as percepções de professores acerca de sua autoconsideração como profissionais ou trabalhadores, e concluiu que, mesmo entre os membros de entidades sindicais, não há consenso sobre a utilização de uma ou outra categoria. Ela chama a atenção para o "caráter híbrido" das atuais identidades docentes. Cláudia Vianna (1999) também evita ver na identificação com os trabalhadores um movimento de passagem, já que as antigas representações não desapareceram e as novas são por vezes fragilmente assimiladas, expondo fissuras na categoria que ficaram evidentes nos anos de 1990. Em sua pesquisa, a dimensão profissional aparece em primeiro plano nos relatos, em detrimento da dimensão de "classe". O "nós" indicado pelos professores tinha como principal referência "uma identidade profissional - 'nós professores da escola' - e não uma identidade de classe - 'nós professores-trabalhadores"' (VIANNA, 1999, p. 200). 
Por fim, e, sobretudo, a noção de profissionalização remete à valorização de um saber pedagógico específico que, num contexto de tendência à proletarização, acaba deslegitimado com a forte presença de outros "especialistas" no campo educacional.

Gilberto Dimenstein [jornalista, articulista do jornal Folha de S. Paulo e da Rádio $C B N]$. Eu já li artigos dele, e já participei de uma palestra com ele lá na Diretoria de Ensino, disseram que era uma capacitação, enfim. Não são todos, mas a maioria deles [jornalistas] acha que o professor é culpado da situação da não aprendizagem, da indisciplina na sala de aula. Geralmente, o professor é muito criticado no meio jornalístico, na mídia, como dizem, é tratado como se... como alguém que não sabe trabalhar. O Gilberto Dimenstein mesmo, lá na capacitação, nos falou assim: "O professor tem que saber fazer...", aí ficou dando exemplo: “Ah, em tal escola...". Dando o exemplo de uma escola pública, em que os professores arregaçaram as mangas e implantaram vários projetos na escola e que mudou a realidade da escola, a escola passou a ter um ensino de qualidade, os alunos passaram a gostar da escola, a respeitar os funcionários, e que a escola mudou completamente, mas tudo porque os professores arregaçaram as mangas. Como quem diz: os professores da rede pública - não estou dizendo todos, mas ele quis colocar todos no mesmo saco - não arregaçam as mangas, não trabalham, não sabem trabalhar, porque tem que trabalhar assim, assim, assim; ensinando coisas que a gente... que eu não vejo novidade nenhuma naquilo lá, os professores já fazem nas escolas [Cristina].

Essa tendência é reforçada pelo discurso acadêmico-científico que defende o resgate da "reflexividade" pela docência. Paradoxalmente, mesmo essa iniciativa carrega "os germes de uma desvalorização da profissão" (NÓVOA, 1999, p. 15), uma vez que traz com força ao campo educacional as autoridades científicas, deslegitimando os professores como produtores de saberes e como pensadores desse campo. João, o único dos professores entrevistados neste estudo a participar de um grupo de pesquisa sobre políticas educacionais, chama atenção para a necessidade de ampliar a presença do professor nesses espaços. O projeto de que João participa faz parte do Programa Observatório da Educação da Coordenação de Aperfeiçoamento de Pessoal de Nível Superior - CAPES, em que professores da educação básica recebem bolsa de pesquisa.

Isso é outra experiência muito importante; que eu acho que mais do que a Academia pode ajudar o professor, o professor tem muito mais para ajudar a Academia nesse sentido. De trazer a experiência mesmo, trazer o que está acontecendo; porque, às vezes, o pessoal se afunda 
aqui [na universidade] em questões, que na hora não está colocado, não... não funciona daquela forma que estão pensando.

Arroyo (2002) alerta ainda para as contradições que o discurso do profissionalismo carrega, a depender do ponto de vista adotado. Se, por parte da categoria, presta-se a reafirmar sua valorização e reconhecimento, por outro, do lado da sociedade, pode servir de justificativa para adiar esse reconhecimento, justamente pela falta dessas competências e do domínio desses saberes que fariam dele um profissional.

\subsection{As Difíceis, Estafantes e Constrangedoras Condições de Trabalho}

"O como trabalhamos nos forma ou deforma, como profissionais e como pessoas" (ARROYO, 2002, p. 115). As condições de trabalho dos professores são, conforme lembra Arroyo, capazes de marcar o que pensamos e a consciência que temos. Algumas dessas condições despontam com ênfase da fala dos professores, revelando outros componentes importantes do quadro que estamos buscando reconstituir: a relação contratual com o estado, se concursado (efetivo) ou contratado (temporário); o número de alunos por turma e a infraestrutura das escolas; a remuneração e a evolução funcional; a participação nas decisões da escola e a intensificação do trabalho.

Em São Paulo, a precarização do trabalho docente ganha contornos expressivos, a despeito de sua condição de unidade mais rica da federação. A maior parte das funções docentes no estado (94\%) encontra-se na rede pública de ensino. Quase 220 mil professores são contratados pela rede estadual e cerca de 150 mil atuam somente em redes municipais nos 645 municípios paulistas (MEC/INEP, 2009). A proporção de professores temporários ou substitutos contratados pela Secretaria Estadual de Educação é a maior do país: quase $50 \%$ dos docentes são não efetivos, enquanto a média nacional de professores submetidos a esse tipo de contrato de trabalho não chega a $20 \%$ (UNESCO, 2004). Não há dados sobre o número de professores temporários nas redes municipais, e cada município possui uma legislação própria sobre o tema. Uma referência nacional vem se esboçando no projeto de Plano Nacional de Educação para que a taxa de efetivos nas redes não seja menor que $90 \%$ até 2021 - o que representaria 
um longo caminho a se trilhar no caso do estado de São Paulo.

Professores da rede estadual contratados na categoria Ocupante de FunçãoAtividade (OFA), ou não-efetivos (atualmente, “Categoria O”), não são concursados e, portanto, não possuem estabilidade. Além disso, não têm prioridade na atribuição de aulas, que são escolhidas primeiro pelos professores efetivos, o que faz com que muitas vezes, ao chegar o mês de dezembro, tais professores - comumente chamados de “eventuais" - não saibam se terão aulas no ano seguinte. Essa situação funcional e as diferenças de estatuto entre os professores da rede pública, cuja legislação sofre constantes remendos para suprir a demanda da Rede, geram competição e situações constrangedoras.

[Quando se é eventual] tem que ir conquistando com seu trabalho, sua submissão. Eu senti isso, e sei que ainda tem outros que ainda sentem. Trabalhei numa escola que tinha uma mesa enorme na sala dos professores onde só sentava efetivo. Quem não era efetivo sentava ao lado, na cadeira, num sofá, mas se sentasse o professor falava assim: dá licença, aqui é meu lugar. Isso é ridículo. Isso foi em 2000, 2002. Não faz tanto tempo. Eu senti isso [...] Fui muito humilhada pela vice-diretora, persisti muito. Senão eu teria desistido ali. Mas no mesmo ano consegui pegar aula, meu objetivo era: não posso ser substituta a vida toda. Tem a discriminação dos colegas que acham que se você não é efetivo, é um nada. Tem a perseguição do pessoal da direção, não digo em todas as escolas, mas na grande maioria é assim. [Rosa]

Isso foi há 12 anos e até hoje eu vejo alguns problemas se repetirem; tem escolas e escolas, mas tem escola que agrega o professor, tem escola que tenta mostrar para o professor eventual que ele tem um determinado lugar; e é um lugar de submissão, faz o que os outros mandam e não tem o direito de questionar [...] Ele não só não é valorizado pelos alunos, como também não é valorizado pelos colegas, tanto da parte do corpo docente, como na parte de gestão também; você tem que estar o tempo todo provando que ele é capaz, que tem competência para estar ali onde ele está, o tempo todo provando, e é bem complicado para quem está "eventuando". [Cilene]

Embora a gente exerça a mesma função que os professores efetivos, estão colocadas as diferenças salariais que existem; as diferenças de um plano de carreira, que não existe para a Categoria $\mathrm{O}$; as diferenças na atribuição de sala, você chega, pega o que resta, e isso que resta, normalmente, são as piores salas que os professores... na maioria das escolas, eles montam sala de aula com um caráter bem excludente, 
separa os alunos que eles consideram ruins, com os alunos que eles consideram bons... E aí eles acabam pegando o que eles consideram bom, e a Categoria $\mathrm{O}$, normalmente, pega as salas mais complicadas; e que são complicadas não pelos alunos, mas pelas condições colocadas. [João]

Por mais que cerca de metade dos professores esteja na rede por meio de concurso, a experiência do vínculo precário foi vivida pela maioria dos profissionais e ainda é muito viva em sua memória. A incerteza na atribuição de aulas e a instabilidade dos contratos temporários são fatores importantes a considerar no processo de afastamento do debate público, uma vez que tendem a fragilizar as condições de envolvimento crítico nas questões do cotidiano escolar. Percepção unânime entre os professores entrevistados, a atual "desunião" dos professores e a ausência de mobilização teriam como fator-chave a própria precarização da carreira; a fragilidade do vínculo empregatício de metade dos professores do estado estaria, segundo os professores, na origem dessa "apatia".

No ano passado teve paralisação e a pauta principal era a Categoria $\mathrm{O}$. Obviamente, como Categoria $\mathrm{O}$, eu fui lá defender a paralisação e tal. E aí, digamos, $90 \%$ dos professores falaram que iam parar; e eu, didaticamente, coloquei um cartaz na Sala dos Professores, para os professores irem lá e colocar o nome afirmando que iam paralisar; aquilo serviria para os professores da tarde verem que havia uma aderência dos professores da manhã e assinarem também. Só que nesse entreturno, eu fui embora, e aí a Diretora arrancou o cartaz e colou na porta da escola, falando para os pais verem os professores que não iam dar aula para os seus filhos na semana seguinte. Foi uma situação superconstrangedora. Para a Categoria $\mathrm{O}$, esse tipo de atividade sindical é muito arriscado, por conta de que para te desligarem da rede é muito rápido, assim como para ligarem você na rede é muito rápido. É só falarem que você faltou esses dias sem justificar, e faltas injustificadas são duas só, se você faltar três dias injustificadamente, você está desligado da rede [...] o que ela fez é uma obscenidade quase, era um caso para, no mínimo, chamar o sindicato. E não foi feito nada. Ninguém quis fazer nada; muito pelo contrário, esse tipo de atitude dela, ao invés de chamar os professores para ficarem mais combativos, pelo contrário, fez os professores recuarem. [João]

Mais adiante, no tópico 2.5, serão desenvolvidas mais a fundo as questões sobre engajamentos e formas de atuação política dos docentes.

É sabido que parte expressiva do tempo que o professor dedica ao seu ofício é 
destinada a atividades extraclasse, tais como correção de trabalhos, preparação e planejamento de aulas. Apenas recentemente, com a Lei do Piso Salarial Nacional para o Magistério (Lei $\mathrm{n}^{\circ}$ 11.738/2008), esta dimensão do trabalho foi formalmente reconhecida - e inclusive ratificada pelo Supremo Tribunal Federal, após questionamentos apresentados por cinco governadores (CAMPAGNUCCI, 2011). O avanço da legislação consiste em ter estabelecido este e outros quatro pontos fundamentais, entendidos como indissociáveis para a valorização da categoria: 1) determina o valor mínimo que um professor deve receber para uma jornada de 40 horas semanais em todo território nacional (valor, na época, afixado em $\mathrm{R} \$ 950,00$ ); 2) atualização anual do valor do piso, tomando-se como referência o valor-aluno do Fundo Nacional de Desenvolvimento e Manutenção da Educação Básica - Fundeb; 3) a garantia de que este valor seja percebido como vencimento inicial da carreira, ou seja, sem somar bônus e gratificações para atingir esse valor; 4) fixa o mínimo de 1/3 de atividades extraclasse para a composição da jornada e 5) todos os entes federados devem elaborar seus respectivos planos de carreira. No entanto, em 2011, três anos após a promulgação da lei, a CNTE contabilizava que 21 dos 27 governadores ainda não cumpriam integralmente a norma, em especial no que se refere ao dispositivo que garante 1/3 da jornada para atividades fora da sala de aula - São Paulo sendo um desses estados.

Os dados disponíveis sobre a jornada de trabalho dos professores do Brasil, coletados a partir de questionário da PNAD/IBGE, não nos permitem conhecer a maneira como esta se divide hoje, já que não demanda especificamente o tempo dedicado em atividades extraclasse (ALVES; PINTO, 2011). Ainda assim, supondo-se que a maior parte dos professores que responderam a esse questionário tenha considerado sua jornada na escola, chega-se a um número elevado de horas dedicadas ao ensino:

$27,1 \%$ situam-se no que poderíamos chamar de uma jornada parcial de trabalho (entre 20 e 25 horas/semana) e $36 \%$ situam-se na jornada integral (40 horas/semana). Preocupa o fato de que 51,3\% dos professores da educação básica possuam uma jornada igual ou superior a 40 horas semanais. Se nossa hipótese estiver correta, os números declarados são preocupantes quando se pensa em qualidade do ensino. Tomando como referência um terço da jornada total como sendo de horas dedicadas a atividades extraclasse (como estabelece a 
Lei $11.738 / 2008$ ), teríamos mais de $70 \%$ dos docentes em jornada igual ou superior a 39 horas semanais de trabalho, o que desmente a tese da jornada mais reduzida dos professores. (ALVES; PINTO, 2011, p. 620)

Com relação a São Paulo, os dados do Censo Escolar 2009 indicam que mais de $26 \%$ dos professores lecionam em dois ou mais estabelecimentos, mas não há informações sobre o número de docentes que acumulam empregos ou cargos distintos.

A jornada de trabalho oficial dos professores da rede estadual, ou seja, aquela prevista na legislação ${ }^{26}$, pode ser básica (30 horas) ou inicial (24 horas), composta por horas-aula e horas-atividade. Aos professores da Categoria “O”, no entanto, a regra não se aplica: os docentes temporários são remunerados de acordo com a carga horária que cumprirem. A mesma lei que regulamenta o trabalho desses professores define que, em caso de acúmulo de cargos, a carga horária não poderá ultrapassar o limite de 64 horas semanais.

Minha rotina de vida é, na verdade, uma rotina de trabalho. Eu acordo, eu venho para cá, eu trabalho aqui [escola da rede municipal] das 07:00 até 13:30; aí eu volto para casa, eu faço projeto a tarde aqui, então eu fico aqui, de novo, aí eu volto para a casa, de 13:45 até 17:00; aí eu saio daqui e vou para outra escola, que é onde eu fico das 19:00 às 23:00. [Sandra]

Também é elevado o número de alunos por turma e a quantidade de turmas assumidas por docente - um professor de sociologia, por exemplo, pode chegar a ter mais de 800 alunos para compor sua jornada.

É bem complicada a realidade nesse aspecto, a quantidade de alunos, por sala [cerca de 40], é absurda, na minha opinião. Não dá, é impossível. Não dá para fazer bem feito. [Sandra]

É uma média de 45 , tem sala que tem 42 , tem sala que tem 40 ; mas, a média é essa; tem sala que tem 47 , por exemplo. E tem dia que eu dou uma atividade, na qual eles estão tendo dificuldades; e é todos chamando ao mesmo tempo e querendo atenção, eles ficam desesperados; então, eu já tenho dificuldade, não é que eu tenho

${ }^{26}$ SÃO PAULO. Lei complementar no 836, de 30 de dezembro de 1997. Institui plano de carreira, vencimentos e salários para os integrantes do quadro do magistério da Secretaria de Educação e dá outras providências correlatas. São Paulo, 1997. 
dificuldade, eu sinto a dificuldade deles muito maior ali. Aí você imagina com uma turminha com 40 alunos, de $5^{\circ}$ Série, em que eles estão pegando fogo. [Cilene]

Outra dimensão da precarização do trabalho docente - aquela que mais tem visibilidade pública - manifesta-se como desvalorização econômica da profissão. A retórica da valorização dos professores, como se verá adiante, clama principalmente por ganhos salariais e competitividade da carreira, que deve ser capaz de "atrair os melhores" ${ }^{27}$. Atualmente, os salários oferecidos aos educadores equivalem a cerca de $60 \%$ da remuneração que recebem profissionais com a mesma escolaridade (PNAD, 2009). Esta realidade varia conforme a região, mas é importante frisar que, mesmo em estados mais ricos como São Paulo, que remuneram melhor seus professores em relação a outras unidades da federação, os salários dos docentes não são competitivos diante das outras opções de trabalho e do custo de vida que apresentam (GATTI; BARRETO, 2009). Assim como outras professoras entrevistadas, Cilene conta que tentou recorrer a outros empregos, antes de firmar-se como professora efetiva:

Eu estava tão revoltada com a Área da Educação, que eu saí para trabalhar de caixa de supermercado, para mim era indiferente o serviço que ia exercer, desde que fosse fora da Área da Educação. E aí depois do mercado, eu trabalhei na parte de Telemarketing, depois trabalhei com a parte de Telefonia Móvel; e aí, por ultimo, trabalhei de bancária, e foi por isso que eu não queria sair, que eu estava satisfeita lá; aí no primeiro ano eu tentei conciliar os dois, e aí no segundo ano já não deu, porque os horários batiam [...] Como a área pública tinha uma certa estabilidade por ser concursada, eu acabei optando pelo setor público.

Um indicador de que a questão da precarização passa a ser considerada de forma mais consistente é o espaço que a discussão ganha, mais uma vez, no próximo PNE. A valorização dos professores é uma das dez diretrizes do plano, e políticas voltadas à carreira docente são tema de quatro das vinte metas propostas no projeto de lei (metas $\mathrm{n}^{\circ} 15$ a 18), além de serem objeto de dez estratégias dispostas em outras sete metas. São

27 Conforme explicitado mais adiante no tópico sobre as representações dos docentes na mídia, o discurso pela valorização da dimensão econômica da carreira docente não vem dissociado de uma contrapartida dos professores, seja pela "compromisso com o aprendizado" ou pela adoção de mecanismos mais efetivos de avaliação e monitoramento de seu trabalho. Ainda assim, ao que indica recente análise de editoriais e artigos de opinião realizada no âmbito desta pesquisa, o discurso de que o aumento de salário, por si, não gera melhoria de qualidade parece ter perdido espaço no debate público. 
$\operatorname{propostas}^{28}$ relativas a vários dos desafios postos atualmente para a questão docente: a valorização no plano econômico com o cumprimento da Lei do Piso Salarial Nacional para o Magistério, a instituição de planos de carreira e melhoria das condições de trabalho - uma delas é enfática ao estabelecer que, em dez anos, 90\% dos professores sejam efetivos e concursados (o que em São Paulo, como já vimos, representaria um expressivo salto). Uma das metas - a de equiparar o salário dos docentes aos de profissionais com formação equivalente - implicaria praticamente dobrar os atuais salários médios da profissão (ALVES; PINTO, 2011).

O desprestígio da carreira e sua baixa remuneração se refletem na diminuição da procura pela profissão, por parte dos jovens, especialmente na educação básica. Em um estudo exploratório que buscou apreender a percepção dos jovens sobre "ser professor" e sobre o trabalho docente, aprendemos que os jovens percebem o professor como um profissional desvalorizado, pelo "baixo salário" e pela "carga horária excessiva", embora enalteçam a profissão docente como uma "profissão bonita", uma "função nobre", "um trabalho fundamental para a formação do indivíduo" (GATTI, 2009). Dadas as dificuldades intrínsecas à profissão citadas pelos jovens, para a maioria dos estudantes que participaram dessa pesquisa a profissão docente não representa uma possibilidade profissional: apenas $2 \%$ deles (31 de 1.501 dos alunos) indicaram, como primeira opção de ingresso à faculdade, o curso de Pedagogia ou alguma outra licenciatura. Todas as precariedades descritas neste tópico, de maneira difusa, também levam a processos de frustração daqueles que já exercem a profissão, sentimento que a maioria da categoria expressa (GATTI, 2010). Associados a experiências específicas de vida e trabalho, são fatores de desmotivação das docentes em exercício.

\subsection{Feminização e a Condição das Mulheres na Docência}

A dimensão de gênero não pode estar ausente de um estudo que pretenda analisar a profissão docente. No Brasil, atualmente, cerca de $80 \%$ do professorado da

28 A CNTE participou ativamente do processo - desde a Conferência Nacional de Educação, que discutiu propostas para subsidiar o plano em 2010, até a sua tramitação na Comissão Especial criada para esse fim em 2011. A confederação sindical integrou articulações da sociedade civil que incidiram na elaboração do Plano e foi responsável pela elaboração de 58 emendas ao projeto, muitas delas acatadas pelo relator. 
educação básica é composto por mulheres, sendo que a predominância do trabalho feminino se verifica sobretudo nos segmentos iniciais da escolarização - na educação infantil, 97\% dos docentes são mulheres, e o percentual cai no ensino médio, nível em que o sexo feminino corresponde a dois terços do total de professores (MEC/INEP, 2009). Nos anos iniciais do ensino fundamental, a predominância feminina já vem ocorrendo desde os anos de 1920 no Brasil (CARVALHO, 1996). A partir de então, houve uma ampliação massiva da força de trabalho feminina, processo chamado de feminização da docência. Classe, gênero e raça são condições que empurram jovens mulheres pobres para o magistério. Essas questões surgem nas falas de algumas professoras entrevistadas com afirmações como "não escolhi ser professora; fui escolhida".

O fato de a docência ser uma ocupação feminina é frequentemente apontado como causa para vários dos males que a acomete, seja pela produção acadêmica ou pela própria organização sindical da categoria. Os autores que se dedicaram a estudar as transformações do trabalho docente procuraram verificar em que medida a feminização da profissão operou sobre seu valor social, estabelecendo conexões entre gênero e proletarização ou desprofissionalização. No entanto, conforme apontam Carvalho (1999) e Vianna (1999), alguns autores, ao fazer isso de forma automática, sem questionar a discriminação de gênero, acabam por reforçar imagens historicamente atribuídas às mulheres, tais como os mitos da feminilidade por trás da escolha profissional, a vocação e a doação para o trabalho.

Sem deixar de lado a preocupação de não incorrer em semelhantes correlações mecânicas e/ou reforçar estereótipos e preconceitos, uma pesquisa sobre o silenciamento dos docentes deve levar em conta as dificuldades e obstáculos que a condição de gênero pode impor às professoras para a fala e participação na esfera pública. A postura acrítica e silenciosa da categoria é frequentemente apontada como consequência da predominância das mulheres no professorado, mas Vianna (1999, p. 198), que analisou a crise da ação coletiva docente ${ }^{29}$, rejeita essa tese. "Há evidências de que a apatia e a submissão estão presentes em sua socialização, mas também há tentativas de recusa desse caráter de subordinação e de passividade.”

A jornada dupla, ou tripla, enfrentada pelas professoras é uma das dificuldades

29 A dimensão política da profissão docente é objeto de análise mais detalhada adiante, no tópico 2.5. 
mais evidentes:

Não, esse ano não tenho tempo livre... assim, casa e filhos me consomem totalmente; o pouco tempo que me resta, entre eu chegar em casa e o outro bebê chegar da creche, eu já entro no computador para preparar atividade, senão eu não fizer nesse tempo, eu não tenho como fazer depois; ou à noite, de madrugada. [Cilene]

Por outro lado, muitas mulheres enxergam na docência uma maneira de compatibilizar trabalho e maternidade, por causa dos horários relativamente flexíveis. É o caso da própria Cilene, que deixou seu trabalho como bancária, em que tinha salário maior, para poder cuidar de seus filhos e seguir com a vida profissional:

Acho que para qualquer pessoa que trabalhe fora e tenha filhos pequenos é tão complicado quanto. Mas essa Área da Educação é bacana nesse sentido, porque há uma maior flexibilidade, que se você se trabalhasse numa empresa por 8 horas.

\subsection{A Condição Formativa em Instituições de Controvertida Qualidade}

Se, por um lado, as professoras e os professores entrevistados reivindicam status de profissional; por outro, falam, com angústia, sobre as dificuldades pedagógicas que enfrentam no cotidiano escolar e a insuficiência dos cursos de formação - inicial ou continuada - para lidar com essa realidade:

Infelizmente, acho que a realidade dos cursos [de formação continuada] é diferente da prática. Com essa história da progressão automática, ele chega cada vez mais fraco no ensino médio. Eles entendem que o aluno já tem uns pré-requisitos que eu acredito que nem sempre são verdadeiros. A preocupação é ótima: o curso, muitas vezes... [...] É uma angústia que eu vejo [nos professores], tanto no Estado como na Prefeitura. A gente vê que infelizmente as coisas estão caindo, e a gente está de mãos atadas, porque não depende de boa vontade, não depende da sua aula, depende do contexto geral. Mas eu vejo nesses cursos que eu faço, nesses fóruns, essa angústia... [os professores falam] "nossa, eu queria aplicar isso, mas não fluiu...". [Nilce] 
A formação acadêmica dos docentes é um dos aspectos mais abordados pela imprensa ao tratar dos problemas de qualidade enfrentados pela educação básica pública no Brasil: segundo o ponto de vista dos agentes que participam do debate público, o professor, mal formado, não tem condições de garantir aos alunos o aprendizado de conteúdos elementares. São frequentes análises e opiniões que atribuem o fraco desempenho das redes de ensino em avaliações externas a deficiências na formação dos professores, embora este seja apenas um dos vários elementos a serem considerados para o sucesso das políticas educacionais. A formação - inicial e continuada - dos docentes da educação básica pública é também elemento-chave para a constituição da identidade profissional dos educadores, para a percepção que a sociedade tem desses profissionais e que estes têm de si próprios, além de fator determinante no processo de profissionalização da docência (GATTI, 2010).

O estado da arte das políticas de formação docente no Brasil (GATTI; BARRETO, 2009) revela como a área sofreu o impacto do rápido crescimento das redes de ensino nas últimas décadas para dar conta da nova demanda por profissionais. As tentativas de estruturação de um currículo comum para a formação de professores são recentes e ainda enfrentam inúmeros desafios para ser implantadas. Foram várias as adaptações operadas para suprir as escolas de educadores: "expansão das escolas normais em nível médio, cursos rápidos de suprimento formativo de docentes, complementação de formações de origens diversas, autorizações especiais para exercício do magistério a não licenciados, admissão de professores leigos etc." (GATTI; BARRETO, 2009, p. 11). Atualmente, 67,6\% dos docentes são graduados em nível superior, sendo que, deste grupo, 23,3\% cursaram especialização e 1,3\% possui título de mestre ou doutor. Cerca de um terço dos professores possui certificação de nível médio, sendo que a maior parte deles leciona na educação infantil $(49,8 \%)$ ou nos primeiros anos do ensino fundamental (36,5\%) (MEC/INEP, 2009).

De fato, uma formação de qualidade tem papel fundamental para a valorização da carreira de professor: "o prestígio pode começar por aí” (GATTI; BARRETO, 2009, p. 252). O nó das políticas de formação docente hoje consiste em propiciar um percurso capaz de combinar o conhecimento profissional e o conhecimento didático. Essa ênfase nos problemas concretos da escola e do cotidiano docente é também um elemento de valorização pessoal e profissional "pois traz implícita a necessidade de uma ação integrada do coletivo dos educadores na construção de novas alternativas de ação 
pedagógica” (p. 227). João relata, por exemplo, que está tentando estudar e buscar referências com outros professores para resolver um problema para o qual ele não teve formação alguma: alfabetização de alunos no segundo ciclo do ensino fundamental [de 11 e 12 anos]:

está sendo um desafio para mim, já... desde o primeiro dia de aula [...] logo depois que termina a aula, você já está meio acabado da sexta aula, você diz: agora eu vou almoçar. Não, agora eu vou lá para lidar com a alfabetização dos moleques [reforço no entreturno]. E aí quando chega lá é muito difícil, porque a minha formação não é pedagogo; então, eu estou tentando... o desafio é esse, eu estou estudando para entender um pouco de alfabetização e poder lidar. [João]

Convivem nesse cenário outras tensões. Avaliações do desempenho profissional - muitas vezes ancoradas no desempenho dos alunos em avaliações externas - são introduzidas nos sistemas oficiais de ensino menos como ferramentas de diagnóstico das lacunas de formação e mais como forma de controle do trabalho docente, sobretudo quando vêm atreladas a bonificações. Na mídia e no discurso dos gestores, a responsabilidade por resultados tende a ser dissociada da discussão sobre as condições em que se desenvolve a docência, e recai com mais frequência sobre os indivíduos - e mais raramente sobre as instituições formadoras.

As instituições formadoras, por sua vez, não têm sido o espaço ideal de socialização e convívio social e cultural, muito em função do reduzido tempo que os jovens aprendizes, estudantes e trabalhadores podem dedicar à sua trajetória escolar. Tornam-se, nas palavras de Arroyo (2002, p. 130) "frequentadores de disciplina, em tempos espremidos, corridos, e os professores quase convivem com os futuros mestres apenas nos tempos formais de aula. O que formaliza o convívio, a socialização e o aprendizado. O que enfraquece esses tempos e suas possibilidades formadoras". Dessa maneira, os futuros mestres têm poucas chances de participar de debates, eventos culturais, seminários e mesmo, conforme lembra Arroyo, mobilizações políticas, levando - ou deixando de levar - essa bagagem para sua atuação profissional. Após a formatura e durante o exercício da docência, a privação dos docentes de certos bens culturais básicos mantém-se, já que seus tempos continuam espremidos e corridos. Provenientes dos "segmentos mais desfavorecidos da população, [são] portadores de um 
capital cultural insuficiente para o exercício da função docente pela escassa oportunidade de fruição de bens culturais como a leitura de jornais e obras literárias, a frequência a eventos artísticos" (GATTI; BARRETO, 2009, p. 233).

Os professores relatam falta de tempo para frequentar cursos, debates, atividades culturais, atividades de lazer. E por mais que o Estado passe a oferecer oportunidades de formação, como o mestrado, a carga de trabalho e o baixo retorno (em termos de evolução funcional e salarial) são vistos pelos professores como empecilhos:

É uma classe que deveria estudar muito, mas que não tem tempo para isso, porque se você quer ter um salário básico, um salário bom, você não vai ter tempo de fazer mais nada, você não vai ter tempo de viver, você não vai ter tempo de estudar, você não vai ter tempo de investir em você $[\ldots]$ Eles falam: o professor vai poder se formar, vai poder estudar, ele vai não sei o quê. Tá, e que horas? Se você vai ter que ter dois cargos e ainda fazer uma hora-extra para conseguir se manter? "O Estado vai pagar Mestrado", não sei... Tudo bem, o Estado vai pagar Mestrado, te obriga a ficar vinculado por cinco anos ao Estado, e com o salário que você ganha no Estado, não dá para viver. [Sandra]

\subsection{As Condições de Participação Política Dentro e Fora da Escola}

O silêncio significa, de fato, que os docentes estejam alheios às questões que mobilizam o campo educacional hoje? Trata-se apenas da invisibilidade no debate público ou atinge também o envolvimento crítico nos assuntos da escola e, mais amplamente, das políticas educacionais? Significa que não participam politicamente da discussão pública sobre educação? Neste último caso, a ação política estaria restrita a certo tipo de militância? A busca de respostas a questões como essas mobilizou estudos sobre o trabalho docente nas ultimas décadas, com diferentes abordagens de acordo com contextos de maior ou menor visibilidade da categoria como sujeito coletivo, ator sindical.

Nas entrevistas realizadas no âmbito desta pesquisa, ficou evidente a existência de uma fissura entre o ambiente escolar - mais especificamente, a "sala dos professores", ou o ambiente de interação do corpo docente -; e da porta da escola para fora, ou seja, o espaço público de maneira ampliada (mídia, debates e outros fóruns). Na mídia e em espaços de elaboração de políticas educacionais (conselhos, poder 
legislativo), os docentes não se reconhecem e não reconhecem esses espaços como meios de intervenção possíveis. Conforme será abordado mais adiante, no Capítulo 3, ou porque sabem que lhes é negada essa participação, ou porque creem que esses canais não lhe são, mesmo, destinados.

É baixa a participação dos professores em diferentes espaços e associações de cunho político, como sindicatos e partidos. Entre os professores das escolas públicas, $6,3 \%$ da categoria afirma participar de associações de bairro, $17,4 \%$ de sindicatos e $7 \%$ dos partidos políticos (UNESCO, 2004). O grau de filiação às entidades sindicais, por outro lado, é bastante alto, embora esse indicador deva ser relativizado, pois "a filiação não pode ser tomada como medida universal da legitimidade vertical da representação do sindicalismo, seja porque parte dos não filiados também participa da ação coletiva, seja porque muitos filiados não participam” (CARDOSO, 1999 apud FERREIRA, 2006, p. 231).

Os três principais motivos para a filiação ao sindicato docente podem ser assim classificados: 1) ideológicos, defesa das crenças; 2) solidários, defesa dos interesses coletivos e 3) instrumentais, defesa de interesses individuais (SERÓN, 1991 apud FERREIRA, 2006). No atual contexto, os motivos de filiação mais comuns parecem ser os instrumentais, embora os outros motivos se misturem com frequência - e nada impede que, após a filiação, o docente passe a identificar-se com outros interesses e defendê-los. Podemos encarar a filiação ao sindicato, ainda que motivada por interesses pessoais, como um primeiro passo para uma participação mais desinteressada. No entanto, verifica-se uma distância grande entre as lideranças das associações e sindicatos e o professorado, e Ferreira aponta um motivo pelo qual essa identidade sindical começou a apresentar fraturas: "as representações que os professores elaboram sobre o sindicato evidenciam uma contradição entre lutas educacionais e lutas sindicais", de maneira que estes passam a encará-lo "como uma entidade desencadeadora de greves" (SOUZA, 1997, apud FERREIRA, 2006).

Eu acho um pouco alienado, assim, a parte... a forma como eles administram essa parte das manifestações, é bem complicado [...] Principalmente, quando há paralisações, boa parte dos professores que paralisam não vão às passeatas; então, eu já não me sindicalizo, porque eu não concordo com a forma que eles administram essas paralisações $[\ldots]$ a gente não percebe muito a interferência positiva 
do Sindicato a favor dos professores. [Cilene]

Na percepção dos professores entrevistados, os sindicatos da esfera municipal são mais atuantes, pois "fornecem cursos, que contam para a evolução funcional" [Nilce]. É recorrente a ideia de que os sindicatos não os representa "de verdade" [Sandra]. A avaliação acontece mesmo entre os professores que desempenham a função de representantes dos sindicatos em suas unidades escolares. A experiência, em vez de aproximar os professores das entidades sindicais, pode acabar afastando, como relata João, recém-ingresso na rede e com histórico de militância política em outros espaços:

Pouca coisa teve de diferença na minha vida, assim, militante mesmo, porque quando eu chegava para as reuniões de RE [representante escolar], eram sempre aquelas disputas entre as forças, eu não entendia nada, os caras estavam falando grego. Os professores que iam também se afastavam, porque eles achavam que aquilo lá não fazia sentido. Então, é um processo, assim, de quase repulsa, se não fosse por a gente ser militante mesmo, a gente chega lá e fala: "isso aqui é uma droga, vou cair fora”. [João]

Soma-se a esse quadro algumas representações difundidas por partidos e organizações da própria categoria acerca de sua consciência crítica e participação política. Segundo Miguel Arroyo, estes preocuparam-se em "conscientizar" e "politizar" os professores, e

as análises mais progressistas, até de lideranças, às vezes destacam outras tonalidades nesse mesmo velho e desfigurado quadro: despolitizados, alienados, sem consciência de classe, sem compromisso político, desmobilizados... Tonalidades que trazem outros aspectos político-ideológicos, mas que somam na visão negativa tradicional, que tanto tem marcado o imaginário social e a autoimagem dos mestres desse ofício. (ARROYO, 2000, p. 203)

Como um exemplo recente dessa posição, destaca-se o trecho de um artigo de professor da rede pública de Boa Vista (RR), em que lamenta a não eleição de nenhum professor no pleito de 2010, a despeito de a categoria docente ser uma das mais 
numerosas no estado:

No primeiro turno desta eleição, encerrado no dia 3 de outubro, vários professores concorreram a um cargo eletivo aqui em Roraima. Nenhum deles conseguiu se eleger, pelo menos dos que se identificaram como representantes da categoria [...] Esse resultado pífio é um indicativo de que ainda não existe uma consciência coletiva entre os professores e que continua prevalecendo o poder econômico nas eleições e o desprestígio do docente. Na hora de decidir em quem votar, parece que o professor se esquece de que pertence a um segmento que vem sendo massacrado, ano após ano, pelos governantes eleitos, que lhe negam as mínimas condições de trabalho, salários compatíveis com sua importância social e exigem resultados positivos à custa de muito sacrifício. ${ }^{30}$

A posição é reforçada pelos professores: "antigamente você tinha movimentos mais fortes, eu cheguei a paralisar, mas hoje é muito fraco isso [...] acho que hoje não existe mais essa politização", afirma Nilce. Para Rosa, o problema é que "cada um olha para seu umbigo": "por exemplo, quando para bancário - parou, parou. Professor não [...] Mesmo dentro da escola. Se você tem um problema comum, dois ou três dão a cara a tapa, os outros ficam na retaguarda".

Vianna (1999) analisou a produção acadêmica sobre a ação coletiva docente e identificou dois blocos de trabalhos, que ganham os contornos do contexto em que foram produzidos. O primeiro deles é tomado pelo otimismo do momento, o início dos anos de 1980, e destacava a força e a capacidade de mobilização da categoria; enquanto o segundo rompe com essa ótica ao introduzir a ideia de uma crise da ação coletiva, a partir da década seguinte. São quatro os indicadores que apontam para uma crise da organização sindical docente nesses estudos: "1) esgotamento das greves; 2) ausência de diálogo com a população usuária das escolas públicas; 3) divergências políticoideológicas nas entidades; 4) distância entre as lideranças das associações/sindicatos e o professorado" (VIANNA, 1999, p. 36). Estava ausente dessas análises a concepção de um agir coletivo como um processo que vai além dos momentos de visibilidade e confronto. Vianna (p. 42) aponta que os autores "quase não exploram as dimensões submersas da ação, muito menos o agir coletivo produzido em outros espaços fora da organização sindical", como a escola pública. Mesmo entre as exceções, que

30 Matos, A.S. Professor não vota em professor. Folha de Boa Vista, Boa Vista, RR, 28 de out. 2010. 
reconheciam nos professores sujeitos da ação, o agir coletivo confunde-se com a militância sindical.

A crise nesse modelo de engajamento em que se privilegiam as necessidades do sindicato provoca o recolhimento à esfera privada ou mesmo o investimento em outras esferas de ação coletiva, que deve ser compreendida em sua complexidade, para além das ações decorrentes da atuação profissional: "diferentes espaços - como o bairro, a mata Atlântica, o sindicato, a escola - e objetivos distintos - como qualidade de vida, melhores salários, condições de trabalho ou pequenos projetos no cotidiano escolar" (VIANNA, 1999, p. 199). Ainda assim, Nóvoa chama a atenção para o desaparecimento dos chamados movimentos pedagógicos, como "coletivos de professores que se organizam em torno de princípios educativos ou de propostas de ação, da difusão de métodos de ensino ou da defesa de determinados ideais" (NÓVOA, 1999, p. 15-16).

Afora o modelo sindical de organização e o engajamento em outras esferas de ação coletiva, é preciso ter em vista ainda três outras dimensões da participação política dos professores: a expressão de seu ponto de vista sobre as questões educacionais ou outras ligadas à sua atuação, tais como a infância, a adolescência e a juventude ${ }^{31}$; a percepção sobre seu papel político na sociedade e na formação dos educandos; e a participação em espaços de avaliação e proposição de políticas educacionais, para além daquelas relativas à estruturação da própria carreira.

A partir da nova LDB, uma das funções do professor que passa a ser reconhecida é seu papel em possibilitar a formação cidadã de seus alunos. Nessa perspectiva, ganham espaço e legitimidade nas propostas curriculares conteúdos e reflexões sobre temas transversais como, ética, sexualidade, meio ambiente, dentre outros. "A política é um desses temas, considerado, pelos docentes, como bastante controverso" (UNESCO, 2004, p. 127). A afirmação de que "o professor deve desenvolver a consciência social e política das novas gerações” é em geral bastante aceita pelos docentes, que "reconhecem a importância de seu papel no tratamento de tais temas": 72,6\% dos docentes têm um grau de concordância muito alto e 18,4\%, um grau alto sobre a questão (p. 128). Também é elevado o percentual daqueles que concordam com a proposição de

31 Esse tema será mais detalhado no tópico seguinte, sobre a relação dos professores com a mídia. É interessante observar como essa forma de compreensão do ator coletivo, identificada com o movimento sindical, reflete na cobertura da imprensa sobre educação. A voz dos professores na mídia restringe-se a questões sobre a carreira e é proferida predominantemente por sindicalistas. 
que "o professor deve se comprometer com a democratização social e política do país", sendo que, quanto maior a faixa etária considerada, maior a proporção de pesquisados que concordam em grau muito alto com a afirmação. $O$ que se percebe, a partir da pesquisa da UNESCO (2004, p. 131), é que há consonância com os preceitos da LDB de que é dever profissional tratar dos temas relacionados à política na escola. "Eles só se dividem quando a questão passa do esclarecimento político dos alunos à militância em sala de aula".

Sandra chama atenção, no entanto, para a dificuldade de se trabalhar esse senso crítico em aula quando a própria estrutura escolar e burocrática não permite esse exercício cotidiano aos professores:

Você vai numa Reunião Pedagógica e dizem: tem que ser assim. Aí você pergunta: "Mas, por que tem que ser assim?" A gente tem que desenvolver a criticidade nos alunos, mas aí quando a gente pergunta o porquê de ter que ser assim: "porque o Governo quer assim, porque a Secretaria de Educação disse que é assim". Então, como que eu posso desenvolver criticidade em outras pessoas, se nem eu tenho direito a ela? Se nem eu, de fato, posso perguntar o que eu quero saber? E se quando eu pergunto, as respostas que eu vou ter são aquelas respostas vazias? [Sandra].

Nove dos dez entrevistados, quando questionados sobre o que pensam sobre seus colegas e sua categoria, criticam sua "desunião" e o "individualismo" dos professores, prontamente. "Deveríamos ter, sim, um pouquinho mais de consciência como um todo, do grupo. Porque aí as coisas aconteceriam. Mas eu não sinto isso. E sozinho é muito difícil. Se o grupo tivesse motivado, uma parceria é legal. Você sozinha é uma exposição que eu não tenho visto que funcione", avalia Nilce. Assim, oscilando entre "um extremo 'individualismo' na ação pedagógica e modelos sindicais típicos de 'funcionários do Estado"' (NÓVOA, 1999, p. 16), os docentes veem sua dimensão coletiva fragilizada, o que, na opinião do pesquisador português, inviabiliza a legitimidade da fala pública: "não vale a pena levantar a voz (as 'vozes'), pois não é por falarmos mais alto que temos mais razão ou que defendemos melhor nossos interesses". A alternativa seria encontrar "espaços de debate, de planificação e de análise, que acentuem a troca e a colaboração entre os professores" (p.16), inscrevendo "a dimensão coletiva no habitus profissional" (p. 19) dos docentes. 


\subsection{A Condição Professoral Vista pela Mídia}

Os veículos de comunicação refletem como jogos de espelhos as imagens do professor a partir das projeções presentes na sociedade, das distintas e por vezes contraditórias noções a respeito de sua figura - muitas delas produzidas e reproduzidas no interior mesmo da categoria profissional. Conforme buscou-se descrever no Cap. 1, os professores são retratados na mídia como heróis, sofredores, vocacionados, vítimas, missionários, salvadores, de um lado; e não deixam de ser preguiçosos, negligentes, mal formados, desmotivados, acomodados, por outro. Como discutido nos tópicos precedentes, as imagens que carregam traços do sacerdócio não foram substituídas pelas de trabalhador; são modelos que convivem no presente em permanente tensão, tanto no plano individual quanto no coletivo (VIANNA, 1999, p. 29).

Você fala nos lugares que você é professor, os caras olham para você com pena. "Pô, é do Estado ainda? Está ferrado". E é isso; ou é como coitado, ali; ao mesmo tempo, salvador. Você é coitado, está sofrendo todas as contradições possíveis, periga apanhar do aluno, e todas essas coisas assim que criam um imaginário, inclusive, né. $O$ que sai bastante, assim, no debate público sobre o professor, é que a escola na periferia é o pior lugar do mundo, e que lá o carro dele vai ser riscado; e, normalmente, aqueles estereótipos da classe média sobre o que é uma periferia, né. Aí te olham com esse olhar, assim: "Pô, coitado, é professor, não recebe salário direito, precisa fazer mil jornadas para conseguir se sustentar". E também, né, colado com isso, vem aquele discurso: "Bem, mas se ele faz tudo isso e ainda está lá, é porque ele é um cara muito legal, um salvador da pátria, ele é que vai salvar tudo aí, vai salvar essa meninada". [João]

Nessa pluralidade de sentidos, a condição de sujeitos dos educadores permanece fora de foco, em segundo plano, nesse "imaginário social que os secundariza e impregna as políticas de educação de currículos e até de formação e 'valorização' do magistério" (ARROYO, 2002, p. 11).

Houve momentos na história em que a vinculação da profissão ao "sagrado" predominou na imprensa (FERREIRA, 2000), ainda que isso não representasse, 
necessariamente, o reconhecimento dos professores como autoridades em educação. Mas os discursos ganham traços acusatórios à medida que o status decai. Hoje a imagem propagada o aproxima mais da condição de culpado pelos maus resultados dos alunos em avaliações e pelos baixos índices de ensino, coexistindo com outras representações que veem nos docentes heróis que se sacrificam por sua missão (o dia do professor, comemorado em 15 de outubro, é o momento por excelência em que se evidenciam mais as imagens desse tipo). Quando é citado individualmente, o professor aparece como vítima de violência, ou ilustra, ainda, reportagens sobre a má qualidade dos sistemas de ensino, sendo retratado como negligente ${ }^{32}$.

Rodolfo Ferreira (2000) coletou as referências feitas ao magistério no dia 15 de outubro, dia do professor, em um jornal de grande circulação (Jornal do Brasil, Rio de Janeiro) em um período de 60 anos (entre 1940 e 1992). Ele mostra que, durante muito tempo, o docente foi "comparado a santo, anjo, e visto como herói, capaz de fazer qualquer sacrifício para cumprir sua missão" (FERREIRA, 2000, p. 116). A partir da década de 1960, pela primeira vez, "se teve notícia de que, ao menos, parte da categoria não estava satisfeita em ter reconhecimento apenas pela dedicação, pelo sacrifício" (p. 119). Esse processo que o autor classifica como dessacralização ocorreu à medida que se acirraram as lutas por melhores condições de trabalho da categoria. Os docentes adotaram, como estratégia de reivindicação de melhores condições a divulgação de suas dificuldades, postura de certa maneira incompatível com os referentes do sacerdócio e do sacrifício.

o problema da remuneração passou a ser anunciado de todas as formas e em todos os lugares: na mídia e fora dela, na escola, na universidade, através dos movimentos reivindicatórios como greves e passeatas, no rádio, em livro, em sala de aula, em casa, na fila do banco, no supermercado [...] [A categoria] Colocou no para-brisa do automóvel dizeres como "Hei de vencer, mesmo sendo professor". Vestiu camisa anunciando a extinção da profissão. Avisou a sequestradores que, por questões econômicas, não valia a pena levá-los para o cativeiro. (FERREIRA, 2000, p. 122)

O autor segue citando situações em que, pela primeira vez, os docentes passaram

32 Sobre as imagens dos professores atualmente veiculadas, apoiamo-nos nas análises de mídia realizadas pelo Observatório da Educação, da ONG Ação Educativa $(2007,2010)$, das quais a pesquisadora participou com pesquisa e redação. 
a ser ouvidos em reportagens, para denunciar a própria condição. Antes, conforme ele aponta na mesma análise, o professor não havia se manifestado sobre o lugar social em que lhe colocaram, ou seja, com a vinculação de sua imagem a santos, anjos, sacerdotes etc., sequer para dizer que não concordava com ela.

No entanto, se os docentes passaram a ser responsabilizados pelos problemas dos sistemas de ensino, por um lado, por outro a mídia propaga que há um professor que precisa ser resgatado, valorizado, reconhecido: "são bombardeados com uma retórica cada vez mais abundante que os considera elementos essenciais para a melhoria da qualidade do ensino e para o progresso social e cultural" (NÓVOA, 1999, p. 14). A percepção e o diagnóstico de que a valorização dos docentes é urgente e fundamental para a melhoria da educação estão certamente presentes no debate público, mas os sentidos dessa valorização são objeto de disputa pela categoria e outros agentes do campo educacional. Em geral, a retórica da valorização é difusa e pouco aprofundada. A "inflação" retórica em torno do tema tem efeitos muitas vezes contraditórios: em nome da "urgente valorização dos professores", articulistas e editorialistas acabam por reforçar velhas tendências observadas na imprensa, tais como a responsabilização e a culpabilização dos profissionais da educação sobre o mau desempenho dos sistemas educacionais em avaliações externas e um certo clamor por abnegação e sacrifícios. Este trecho de editorial publicado após o anúncio de reformulação do currículo do ensino médio pelo Ministério da Educação - anúncio, por sua vez, motivado pelo mau desempenho dos estudantes dessa etapa de ensino no Índice de Desenvolvimento da Educação Básica (Ideb) - é bastante ilustrativo desse comportamento:

De nada adianta formular parâmetros curriculares maravilhosos se não tivermos profissionais preparados para ministrá-los [...] Um bom educador passa por cima de currículos ruins, supera a falta de infraestrutura, enfrenta a indisciplina e abre oportunidades de vida melhor para seus discípulos. Por isso precisa ser reconhecido e valorizado, mas também acompanhado e cobrado. ${ }^{33}$

A primeira década do século XXI foi o momento forte desse debate. Nesse período, houve um esgotamento do que o pesquisador Juan Carlos Tedesco (2002)

33 Editorial “Além da Reforma Curricular”, Diário Catarinense, 19 ago. 2012. 
chama de "discursos tradicionais" sobre a questão docente. São três: 1) a fala, por parte dos governantes, de reconhecimento da importância dos(as) professores(as) foi dissociada de efetivas medidas para mudar o cenário de desvalorização da profissão desde a dimensão financeira até as políticas de formação docente; 2) a culpabilização dos docentes pelos maus resultados dos indicadores educacionais, assim como sua vitimização pelas más condições estruturais, que deixaram em segundo plano a discussão sobre sua função educativa; 3) por fim, uma abordagem que subestima o papel docente ganhou espaço nos últimos anos - o professor, nem vítima nem culpado, simplesmente não seria importante para o rendimento escolar. A discussão sobre o uso de tecnologias na escola tende a reforçar este último ponto.

Essa mídia que trata o docente de forma predominantemente negativa; que papel tem, para os professores, como fonte de informação sobre os assuntos do campo educacional? Quando questionados sobre a principal maneira de se informar sobre assuntos da educação, os professores evocam não a mídia, mas a rede de colegas, o "bate-papo", a troca de informações na sala dos professores e no horário pedagógico como a maneira mais eficaz de saber o que acontece. Por outro lado, reforçam o caráter distorcido, superficial ou mesmo "manipulador" da imprensa, de modo que somente quem ocupa a posição que eles ocupam estaria em condições de conhecer a real situação da escola.

Acho que elas [as pessoas] não conhecem [a realidade das escolas], eu vejo pela minha família. Outro dia uns professores estavam falando, e eu concordo: só entende de educação quem está dentro da educação. [Nilce]

Aqueles que têm o mínimo de acesso às informações verdadeiras do que realmente acontece na escola, aqueles que têm parentes que trabalham dentro da escola, esses têm um pouco de noção, os outros só têm ciência do que aparece na mídia [...] eu vejo que as informações são bem manipuladas, bem manipuladas; principalmente, por algumas emissoras. Tem emissora que não divulga nenhuma informação sobre a Educação, tem emissora que divulga informações maquiadas sobre a Educação... Por exemplo, a Rede Globo, ela maquia algumas informações, quem está na rede sabe o quê que está acontecendo, mas como é que você vai contar para um maior número populacional, um maior número de pessoas da população que aquilo que está sendo dito numa rede de televisão ... tão tradicional, que o que está dizendo é mentira? Como é que você vai desmentir a Rede Globo? [Cilene] 
[Os jornalistas] deveriam tentar entender. Porque só quem está dentro da sala de aula é que sabe o que acontece numa escola e dentro de uma sala de aula. As pessoas que estão fora da sala de aula, não sabem; o Governador, o Prefeito, os Vereadores, eles não sabem como que é o mecanismo de uma escola; se ele vier um dia só aqui, ele não vai entender toda a engrenagem, como é que funciona. [Dalva]

Por último, é preciso reconhecer que a própria concepção de educação que a mídia sustenta quando trata do tema influencia no reconhecimento social dos docentes, em suas imagens e autoimagens. Essa concepção costuma ser reduzida a um saber instrumental, à preparação para o mercado de trabalho ou ao treinamento da juventude para concursos, provas e vestibulares; e, segundo Arroyo (2002, p. 194),

onde não há uma visão da Educação Básica universal, da educação como direito humano, formação, não haverá possibilidade de afirmar uma cultura profissional específica. Aí está o cerne de nosso prestígio ou desprestígio social e profissional, na visão estreita ou alargada de ensino ou de educação que afirmemos.

\subsection{As Condições Legais, Administrativas e Burocráticas do Silêncio}

Nas falas dos professores, alguns mecanismos de restrição à liberdade de expressão se manifestaram em diferentes dimensões, além da normativa: i) a dimensão legal, com a existência de normas restritivas, tais como artigos dos estatutos municipais e estaduais dos funcionários públicos, presentes em ao menos 17 estados e diversos municípios, que impedem servidores de concederem entrevistas de modo "depreciativo" à administração. Em São Paulo, esse dispositivo foi revogado em setembro de 2009, conforme detalhado no Capítulo 1; ii) a dimensão relacional, por meio da pressão de diretores, desfavorecimento na atribuição de aulas, transferências e outros tipos de retaliação; e iii) a dimensão administrativa, com a publicação de portarias e circulação de memorandos orientando professores a não responder a pedidos de informação da imprensa e outros procedimentos para autorização de entrevistas.

O desconhecimento da lei por muitos profissionais ou mesmo sua 
inaplicabilidade (em São Paulo, não se conhece um processo com base nessa legislação que tenha levado à exoneração de um funcionário) nos remete novamente à hipótese de que não basta analisar o fenômeno apenas do ponto de vista de suas condições de produção objetivas, mas, também, olhar para aspectos subjetivos dessa configuração. Nas entrevistas realizadas no âmbito desta pesquisa, nenhum dos professores fez referência explícita ou mostrou conhecer esse dispositivo específico da legislação; mas, quando questionados sobre a existência de impedimentos para entrevistas, três entrevistados falaram em proibições, e foram enfáticos ao relatar supostas restrições legais:

- Na verdade, nós não podemos dar entrevistas, né; nós não podemos falar com a imprensa. É um impedimento legal.

-É? Como, assim?

- Porque nós não podemos, por exemplo, tem uma situação dentro do meu ambiente de trabalho, eu não posso sair para a mídia e denunciar, entendeu? Nós não podemos, existe toda uma legislação por trás disso.

- Você já soube, lembra qual que é? Alguém falou isso?

- Nenhum funcionário pode prestar, dar entrevista, depoimento, para jornal. Não pode. Para isso o Governo, a Prefeitura, seja quem for, tem uma Assessoria de Imprensa. Toda Diretoria de Ensino, Delegacia de Ensino, tem uma Assessoria de Imprensa, exatamente por isso. Porque nós não podemos sair dando entrevista assim e falando o que a gente quer.

- Mas você acha que é só em caso de denúncia, ou é qualquer... sobre o trabalho, em geral?

- Ah, não sei. Eu acho que sobre o trabalho, em geral; porque nós não podemos ir contra o nosso ambiente de trabalho. É lei, isso é fato, isso é lei; quando você toma posse, você já assina lá a tua documentação, na legislação nossa já tem, e a gente não pode ir contra o nosso local de trabalho; muito pelo contrário, você é um funcionário, você está aqui para melhorar o seu ambiente de trabalho e não para atrapalhar o seu ambiente de trabalho. [Dalva]

- Agora, falar que nós professores não trabalhamos, o professor não faz isso, o professor não faz aquilo, é porque [o jornalista] já não entra em sala de aula. Mas eles não podem entrar, como que eles vão saber o que nós fazemos?

- Eles não podem entrar? 
- Tsc-tsc-tsc. Vamos supor que acontece alguma coisa aqui na escola; eles não podem entrar e eu não posso dar depoimento, nem lá fora.

- Mas o que impede?

- Nós temos os nossos jornalistas, e eles proíbem, por Decreto-Lei, que você não pode falar mal do Estado. [Alberto]

- A gente que trabalha no Estado, se vier um repórter que não esteja autorizado pela Direção para entrevistar os professores, a gente não pode falar nada, a gente não pode dar entrevista.

$-\mathrm{Ah}$, é?

- É proibido. Funcionário público não pode dar entrevista, é proibido. E já aconteceram uns episódios aqui, que veio a imprensa, né; eu nem lembro que TV que veio mais, mas eu acho que foi em 2007; nenhum de nós pôde conversar com o repórter, para poder falar, dar a versão do que tinha acontecido.

- Foi em 2007?

- É. "Não, vocês não podem, vocês podem sofrer um processo administrativo, se vocês forem dar entrevista."

- Quem que falou isso? Quem costuma falar isso?

- A Direção.

- A Direção da escola orienta que não pode dar entrevista.

- Colou um aviso na Sala dos Professores, a gente leu... colocou lá um artigo lá, de uma lei lá, que diz que é proibido; e a gente nem tem oportunidade também, uma oportunidade de conversar com o pessoal da mídia, não tem, não.

- Mas, você acha que tem algum impedimento mesmo para que os professores darem entrevista?

- Eu nem fui investigar isso, né, se é verdade, se é menti... se não é verdade, não sei.

- Mas se aparecesse um jornalista aqui para fazer entrevista, você falaria?

- De uma rede de TV? Eu, para não arrumar confusão, eu preferia ficar na minha, não me manifestar. [Cristina]

De forma difusa e nem sempre explícita, esse conhecimento, ainda que não referenciado na legislação, é evocado pelos professores como motivo para a não participação no debate público - não apenas em depoimento à imprensa, mas também 
na participação em eventos e atividades públicos. É possível que a lei, que continua presente na imaginação coletiva dos docentes, tenha se convertido em autocoação - mas esta não deixa de conviver, bem entendido, com reais ameaças e constrangimentos. Chamamos esse aspecto, aqui, de mecanismos "relacionais" - pois se dão no relacionamento dos professores com a direção, coordenação e outros agentes públicos da estrutura das secretarias de educação. O clima de medo gerado nessa relação é bastante objetivo, e aparece de algum modo na fala de todos os entrevistados (para descrever a própria conduta ou a conduta de colegas):

- Os professores têm medo o tempo todo...

- De discordar?

- De discordar, porque qualquer coisa: Vai cessar o meu cargo. Vai cessar o meu cargo. Ai, eu sou "O", então eu não posso, porque eu sou "O”. Às vezes, eles querem... Ou, por exemplo, eles querem te obrigar, de certa forma, a fazer alguma coisa, ocorre uma chantagem. Eu sou efetiva, mas, até então, probatório no Estado; e eu sentia isso na pele, de uma certa forma: Olha, os outros até podem, mas você está no probatório, você não pode. Como se o probatório fosse um período diferenciado; e, na verdade, não é, você trabalha como professor, como qualquer outro professor, e acontecia isso.

- Tinha essa menção, assim: Você é probatório.

- Isso. Você é probatório; então, olha, você não pode, toma cuidado, você é probatório. E isso acontece, aconteceu comigo por três anos; com o "O", isso acontece o tempo todo, tipo: Olha, se você faltar, vai cessar o seu cargo. Se você fizer greve, vai cessar o seu cargo. Você sabe que você não pode faltar, a greve é falta, mas isso é no Direito Constitucional, ocorre essa chantagem direto o tempo todo; isso pesa muito, dificulta o trabalho. [Sandra]

Essa pressão, na avaliação dos professores, não acontece apenas no âmbito escolar, mas também pode vir "de fora":

Tem, tem. Tem [pressão de fora da escola, da DRE]. A nossa escola, por exemplo, esse ano, ela virou escola prioritária. E nós estamos sendo visados, vigiados o tempo todo, o tempo todo com visita de Supervisores de Ensino para saber como é que está o andamento da escola; e a intenção é demonstrar que os professores estão se 
esforçando para melhorar o andamento da escola e que a escola está caminhando em perfeita harmonia, né. Não é bem isso que acontece, mas é o que se espera dar a entender; então, é complicado, é bem complicado. Eu até entendo a parte da Direção, ela sofre pressão por conta disso, ela tem que mostrar resultados, nem que esses resultados tenham que ser maquiados, entendeu; ela sofre pressão, aí ela pressiona o Vice-Diretor, que pressiona o Coordenador, que pressiona os professores; então, há uma pressão. [Cilene]

Na visão de Sandra, esse é um impedimento real para dar entrevistas. Ela afirma que, caso ainda fosse contratada na "Categoria O", "não teria essa mesma liberdade" de falar com a pesquisadora, e, provavelmente, sequer no âmbito desta pesquisa concederia entrevista. "Eu iria evitar de falar, eu falaria metade do que eu falei":

Aqui [na escola municipal] não, mas, por exemplo, na outra escola [estadual], eu não teria a liberdade, eu não me sentiria livre de falar, porque eu sei que eu teria... por exemplo, eu falo de uma determinada situação que aconteceu na escola, eu sou efetiva, mas a Diretora vai infernizar a minha vida até o final do ano, e se eu permanecer na escola ela vai continuar infernizando. Isso é um baita impedimento [para dar entrevistas], imagina o Categoria $O$, que pode ter o seu contrato cessado por livre e espontânea vontade do Diretor. Ele fala alguma coisa da gestão, ou então você fala alguma coisa sobre Coordenação, você tem contato direto com essa pessoa todos os dias, e às vezes você fala, não agradou, às vezes nem querendo ou não agradar, digamos, e aquilo te custa o ano inteiro; no momento, não: "ah, tudo bem, beleza". Mas, aí depois você começa a ver picuinha, sabe? [Sandra]

João é um dos dois professores entrevistados que já teve diversas experiências como "fonte" de informação para jornalistas - a outra é Elaine. Assim como Elaine, João circula em espaços de debate de ONGs e na universidade, e por isso se tornou referência para alguns repórteres. Em um seminário organizado pelo Observatório da Educação sobre o programa de ensino médio integral, em 2012, João, a partir da plateia, relatou sua experiência como professor "Categoria O" e fez críticas ao modo como a política estava sendo implementada. A visibilidade rendeu-lhe entrevista ao jornal $O$ Estado de S. Paulo, depois. Apesar de concordar em conceder entrevistas, no entanto, acha a experiência "estranha", principalmente pela maneira como a imprensa aborda os temas educacionais. Para João, os repórteres não parecem interessados em efetivamente ouvi-lo, mas apenas validar uma tese que eles já têm ao entrevistá-lo. Em outra ocasião, 
o professor relata que foi abordado, dentro da própria escola, pelo Canal Futura, para falar sobre sua experiência na função de Professor Auxiliar.

- Chegaram perguntando mil coisas, foi muito abrupto, de novo, assim, e eu fiquei meio que sem saber o que falar, assim; e a Diretora olhando para mim, aquela situação de quase coerção, né.

- Mas é no sentido de que a Diretora queria que você falasse?

- A Diretoria queria que eu falasse... e que eu falasse bem do projeto.

- E ela estava acompanhando a entrevista?

- Estava acompanhando a entrevista.

$[\ldots]$

- Na verdade, assim, eles também estavam super, super, super inseguros, porque eles não sabiam direito aonde eles estavam se metendo, assim, não sabiam o que eu ia falar. Foi engraçado, porque logo depois que acabou a entrevista, a Secretaria [Estadual de Educação] me ligou, um rapaz da Secretaria me ligou, perguntando o que eu tinha falado para a jornalista. E aí, beleza, eu falei o que eu tinha falado. Ele falou: "Ah, está bom. Tudo bem. Obrigado". Desligou o telefone, e nunca mais escutei falar nada, eu nem sei se saiu a entrevista no Futura.

O relato de João joga luz sobre duas outras questões, de dimensão "administrativa": os jornalistas e seus veículos necessitam de autorização para entrar nas unidades escolares, autorização esta que deve ser concedida pela Direção, que a depender do caso remete a solicitação à Assessoria de Imprensa da Secretaria (cf. Capítulo 1); e essa Assessoria de Imprensa trabalha ativamente na "contenção de crise" e no monitoramento das falas de professores que se relacionam com a imprensa, antes mesmo que suas entrevistas sejam publicadas. Três dos professores entrevistados [Alberto, Cristina e Dalva, os mesmos que citam impedimentos legais para entrevistas] contaram que receberam instruções desses profissionais (que chamaram de "jornalistas do Estado") em situações que houve forte assédio da imprensa na escola:

- Eles têm um jornalista, e que é do Estado. Então, vamos supor, aconteceu alguma coisa na escola, eles vêm que vêm com a vara verde.

- É mesmo? 
- É, “vocês não podem fazer isso, não podem fazer aquilo, vocês...”.

- Quando acontece alguma coisa vêm os jornalistas, assessor de imprensa, não é?

- Assessor de Imprensa, do Estado. Ele vem igual gavião, você não pode falar nada.

- Ah, eles vêm para evitar que as... os professores...

- Que você fale. Só que eles esquecem que a gente passeia; e se um jornalista me faz pergunta, eu passeando? [...] O Estado te proíbe a falar; porque, basicamente, [quando acontecem problemas graves na escola] a Diretoria vem para cá; principalmente, vem a Dirigente, acontece e "tchum", você já encontra ela aqui. [Alberto]

Todos esses mecanismos, legais, relacionais e administrativos, são, portanto, componentes que não podem ser desprezados na análise da configuração em que se encontram os docentes hoje. Ameaças reais e autocensura convivem nessa trama e, como os outros elementos desenvolvidos neste capítulo, formam disposições e/ou predisposições, práticas e mentalidades no decorrer do processo de socialização. São, portanto, a "concretude do silêncio", aquilo que podemos observar no mundo social e descrever como parte do fenômeno. No próximo capítulo, passaremos a nos dedicar a compreender o processo por meio do qual a subjetivação dessa realidade acontece. 


\title{
Capítulo 3
}

\section{A Subjetivação do SilênCio - Uma Construção Social}

\begin{abstract}
A sociedade é um produto humano. A sociedade é uma realidade objetiva. O homem é um produto social. Torna-se desde já evidente que qualquer análise do mundo social que deixe de lado algum destes três momentos será uma análise distorcida.
\end{abstract}

Peter L. Berger; Thomas Luckmann, A Construção Social da Realidade.

Falávamos como incorporamos o ser professora, professor, como uma outra personalidade, como o outro de nós mesmos. Sabemos pouco sobre como acontecem esses processos de internalização, de aprendizagem, de socialização do ofício que exercemos. Somos e continuamos sendo aprendizes de mestres, de professoras $e$ professores. Onde se dá esse aprendizado? Na escola normal? No curso de pedagogia e licenciatura? No exercício do magistério? Na imagem social que nos impregna na mídia, nas formaturas, na literatura, no cinema, na TV?

Miguel Arroyo, Ofício de Mestre: Imagens e Autoimagens.

Onde e em que circunstâncias, afinal, aprendemos a ser professores e professoras? A reflexão que propõe Miguel Arroyo, destacada na epígrafe deste capítulo, faz uso de um vocabulário caro aos estudiosos das práticas socializadoras. Suas questões nos auxiliam a compreender que, para nos tornarmos professores, todos os elementos apontados por ele compõem-se reciprocamente. Seguindo essa linha de raciocínio, será importante lembrar que o processo de socialização, de acordo com Berger e Luckmann (2011), dá-se em três momentos: exteriorização, objetivação e interiorização, fenômenos que, de maneira dialética, não devem ser pensados como ocorrendo em uma sequência temporal. "Ao contrário, a sociedade e cada uma de suas partes são simultaneamente caracterizadas por estes três momentos, de tal modo que qualquer análise que considere apenas um ou dois deles é insuficiente.” (p. 167)

Sendo a realidade, ao mesmo tempo, objetiva e subjetiva, cabe aqui buscarmos compreender como se articulam, na construção do fenômeno do silêncio dos professores, elementos de ordem objetiva (Cap. 2) e subjetiva (Cap. 3) do processo. 
Seria o silêncio uma disposição ${ }^{34}$ dos professores? Seria uma prática de cultura decorrente de laços sociais, de um mundo objetivo incorporado?

Neste capítulo, pretendemos investigar o que chamamos de "subjetivação do silêncio", isto é, o processo de incorporação da realidade do mundo social aqui descrito. Buscaremos, com o material coletado a partir de entrevistas semiestruturadas, compreender em que medida as críticas e representações negativas atribuídas aos professores descritas no Capítulo 2 - a forma como a sociedade os vê - são assimiladas pelos mesmos na formação de suas identidades/subjetividades - a forma como o professor vê a si mesmo e à sua categoria.

Procuraremos, também, observar em que medida o silêncio pode ser considerado manifestação de um processo de estigmatização (ELIAS; SCOTSON, 2000; GOFFMAN, 2008) resultante de uma configuração desfavorável aos docentes na atualidade, fenômeno este que incide sobre a formação de suas identidades pessoal e profissional. Tal processo pode fornecer pistas para compreendermos por que, mesmo diante da enxurrada de críticas e da possibilidade de dar entrevistas ou participar de debates, o professor "opta" 35 , muitas vezes, pelo silenciamento. A partir do desenvolvimento dessa reflexão, o silêncio será abordado como uma predisposição que se torna uma disposição cultural, incorporada pelos indivíduos ao longo de suas experiências de vida (SETTON, 2008) e em suas relações sociais.

É importante ressaltar que o estudo em questão vale-se de instrumentos e autores da Sociologia - e não da Psicologia - para empreender essa análise. Na perspectiva dos processos de socialização, o indivíduo está, ao longo de toda sua vida, aprendendo e construindo maneiras de ser e estar no mundo, bem como de compreendê-lo e agir sobre

\footnotetext{
34 “A palavra 'disposição' [...] exprime, em primeiro lugar, o resultado de uma ação organizadora, apresentando, então, um sentido próximo ao de palavras como 'estrutura'; designa, por outro lado, uma maneira de ser, um estado habitual (em particular do corpo) e sobretudo uma predisposição, tendência, propensão ou inclinação" (BOURDIEU, 1983, p. 53). Lahire (2002), no entanto, alerta para o risco de não se considerar a dimensão condicional ("circunstancial, contextual") das disposições, reificando traços de personalidade. As experiências são atualizadas, diz, "em função das situações encontradas" (p. 57). Esse cuidado será observado, aqui.

35

Essa "opção", como temos procurado demonstrar nesta pesquisa, não diz respeito apenas a uma decisão ou cálculo racional dos indivíduos em questão. As forças externas e internas que agem sobre ele e nele bem como suas disposições incorporadas fazem com que estes obedeçam a uma espécie de sentido de jogo, ou seja, uma resposta não necessariamente refletida a determinado contexto. "As noções que elaborei aos poucos, como a noção de habitus, nasceram da vontade de lembrar que ao lado da norma expressa e explícita ou do cálculo racional há outros princípios geradores de práticas. (...) De modo que, para explicar o que as pessoas fazem, é preciso supor que obedecem a uma espécie de 'sentido de jogo', como se diz no esporte" (BOURDIEU, 1986, apud LAHIRE, 2002, p. 140).
} 
ele. Mesmo em nossa vida adulta e profissional, somos apresentados a novos "campos semânticos que estruturam interpretações e condutas de rotina em uma área institucional. Ao mesmo tempo, são também adquiridas 'compreensões tácitas', avaliações e colorações afetivas desses campos semânticos" (BERGER; LUCKMANN, p. 179). É esse acervo de conhecimento sobre o mundo que "'programa' os canais pelos quais a exteriorização produz um mundo objetivo" (p. 91), fechando assim o ciclo da dialética fundamental da realidade.

Vale salientar que esse processo inclui o que sabemos sobre nossa própria situação e seus limites, ou seja, é nele que adquirimos a consciência do que podemos/devemos fazer em determinadas situações com base no que nos é transmitido, sem que estejamos "presos" a esse julgamento. Por fim, a assunção de papeis - o estatuto social de pai, estudante, professor etc. - marca a introdução do indivíduos em um setor específico do acervo total do conhecimento possuído pela sociedade, e também implica a interiorização de normas e práticas culturais. Mas

aprender um papel não é simplesmente adquirir as rotinas que são imediatamente necessárias para o desempenho 'exterior'. É preciso que seja também iniciado nas várias camadas cognoscitivas, e mesmo afetivas, do corpo de conhecimento que é diretamente e indiretamente adequado a este papel. (p. 103)

Para seguir com o desenvolvimento desse argumento, cumpre lembrar que, no capítulo precedente, pudemos conhecer com mais profundidade os elementos objetivos da configuração em que se encontram os docentes hoje. Destacamos a estrutura em que estão inseridos e depositamos um olhar ampliado sobre o tempo em que vivem e os processos em que estão implicados os professores. Pode-se dizer que procuramos, com isso, construir uma "macroconfiguração", um feixe de forças externas a que eles estão submetidos. Porém, o processo de incorporação e formação de disposições não é linear, ou seja, não é possível fazer uma correspondência direta entre os fatores objetivos e subjetivos da realidade. Os indivíduos estão submetidos a um contexto (no caso estudado, como se pôde observar, um contexto duradouro), mas sofrem influência não só dessas forças externas como, também, de forças internas a eles. Assim, de acordo com Lahire (2004, p. 330), 
o que determina a ativação de determinada disposição em dado contexto pode ser concebido como o produto da interação entre (relações de) forças internas e externas: relações de força interna entre disposições mais, ou menos, fortemente constituídas ao longo da socialização passada, e que são associadas a maior ou menor apetência, e relação de forças externas entre elementos (características objetivas da situação, que podem ser associadas a pessoas diferentes) do contexto que pesam mais, ou menos, fortemente sobre o ator individual, porque o forçam ou o solicitam mais, ou menos.

Nada do que fazemos ou somos levados a fazer, portanto, pode ser reduzido a nosso passado incorporado. Pois

cada modificação, mesmo pequena, da configuração das forças (do 'paralelogramo das forças', segundo a expressiva sugestão de Norbert Elias) que se exercem sobre nós [...] imprime inflexões significativas a nossas ações e a nossas maneiras de pensar, solicitando disposições paralisadas ou, ao contrário, suspendendo disposições anteriormente ativadas. (LAHIRE, 2004, p. 336)

Dessa forma, é possível explicar as diferentes maneiras como os professores reagem a influências externas, inibem determinada disposição ou, ao contrário, coloquem-na em prática. Ainda que se trate de uma liberdade limitada, podemos, ao conhecer nossas propensões, buscar modificar as influências internas e externas que agem em nós e sobre nós e desenvolver "um autocontrole para conter a força da disposição" ou fazer "arranjos contextuais que deem conta dessa disposição para tentar limitar seus efeitos negativos" (LAHIRE, 2004, p. 336).

\subsection{Tecendo Microconfigurações}

Após apresentar a configuração em que se encontram os docentes em seu aspecto "macro", podemos, neste capítulo, avançar ainda um degrau de análise e buscar reconstituir a "microconfiguração" em que vivem os professores entrevistados - as relações que estabelecem em seu cotidiano, suas condições de trabalho, aspectos da 
condição familiar e de vida. Desse modo, procuraremos identificar alguns indícios disposicionais recorrentes que nos permitam reconstruir as situações em que o silêncio ocorre, bem como algumas de suas nuances e contextos de atualização. As disposições, explica-nos Lahire (2004), não podem ser diretamente observadas pelo pesquisador, mas considera-se que estão "no princípio" das práticas observadas. Para analisá-las, por conseguinte, o pesquisador deve reconstruí-las com base em

1) a descrição (ou reconstrução) das práticas,

2) a descrição (ou a reconstrução) das situações nas quais essas práticas desenvolveram-se, $\mathrm{e}$

3) a reconstrução dos elementos julgados importantes da história (itinerário, biografia, trajetória etc.) do praticante. (p. 54)

Por estarem inseridos em uma pluralidade de mundos sociais e sujeitos a princípios de socialização heterogêneos - e, às vezes, contraditórios - os indivíduos incorporam "estoques" de disposições, na metáfora utilizada por Lahire. O autor esclarece que estes funcionam como repertórios de esquemas de ação (de hábitos) ou conjuntos de experiências sociais incorporadas em processos de socialização anteriores; nesse processo, são adquiridos não apenas os hábitos em si, mas também o "sentido" deles em cada contexto. $\mathrm{O}$ indivíduo "aprende/compreende que aquilo que se faz e que se diz em tal contexto não se faz nem se diz em outro" (LAHIRE, 2004, p. 37).

Além disso, esse "capital de experiências", incorporado sob a forma dos esquemas acima descritos, não é estático, mas sim atualizado em função das situações e do contexto encontrados. "O passado, portanto, está 'aberto' de modo diferente segundo a natureza e a configuração da situação presente" (2004, p. 51). Essas disposições heterogêneas "combinam-se entre si para formar esta ou aquela escolha, esta ou aquela orientação e, mais geralmente, formar um estilo particular de condutas e de atitudes" (p. 327). Uma disposição não é, portanto, uma resposta simples e mecânica a um estímulo externo, "mas uma maneira de ver, de sentir ou agir que se ajusta com flexibilidade às diferentes situações encontradas" (p. 30).

Para falar em disposições, portanto, não podemos deixar de olhar para o indivíduo, suas práticas e trajetórias - ainda que estudemos, aqui, um processo que 
parece atingir de algum modo a uma ampla parcela de uma categoria profissional. Desde o início, com essa preocupação, buscamos identificar o silêncio a partir do material empírico coletado, isto é, de entrevistas com professores e dados da realidade objetiva. Na tentativa de evidenciar os indícios sobre as condições socializadoras responsáveis pela ativação de disposições para o silêncio, apresentaremos a seguir, no formato de perfil, um resumo de cada um dos dez entrevistados, contendo algumas características pessoais, biográficas, profissionais e de sua percepção com relação à mídia e aos outros professores - sem pretender, neste momento, a busca de coerências ou "princípios" que possam explicar suas práticas.

\section{Nilce $e^{36}$}

A escola municipal em que Nilce atua, no Jaçanã, é bastante organizada e enfeitada pelos professores com trabalhos de alunos. De avental, preparava lembrancinhas para o Dia das Crianças na Sala dos Professores, durante seu horário de planejamento pedagógico (JEIF). Tem 43 anos de idade e 18 de docência, é casada e tem dois filhos - o que torna sua rotina bastante complexa, já que concilia o trabalho na Prefeitura com aulas também na rede estadual. Com uma carga horária total de 47 horas semanais, dedica-se a cerca de 150 alunos do segundo ciclo do ensino fundamental e do ensino médio.

Sua mãe ingressou na Educação de Jovens e Adultos quando Nilce tinha 16 anos e cursou faculdade de enfermagem com apoio da filha, não sem muito esforço; recentemente, fez pós-graduação e hoje inclusive dá aulas. Já seu pai era técnico em uma empresa do setor aéreo e trabalhou com eletrônica. Ambos, apesar da difícil trajetória escolar, sempre foram rígidos na cobrança pelos estudos de Nilce e seus irmãos. "Para minha mãe era muito importante isso de ter média, uma boa nota... ela dizia 'vocês só estudam"'. Aos 17 anos, decidiu cursar Ciências e Matemática na Universidade de Guarulhos (UnG), instituição privada de ensino, e depois resolveu ingressar em Administração e Contabilidade. Não imaginava ser professora, pois já trabalhava no setor administrativo de uma fábrica, mas a partir do estímulo de uma colega tentou e "foi ficando". "Eu pensei: será que vou ter perfil? Porque na faculdade é

36 Os nomes dos entrevistados foram trocados para preservar suas identidades, ainda que tenham autorizado sua publicação. As entrevistas foram realizadas entre outubro de 2012 e outubro de 2013. 
diferente o que você estuda e depois o que aplica. Você tem um estudo um pouco mais avançado mas, na prática, deixa a desejar. Acho que a gente aprende mesmo quando vai para o campo de batalha, preparar uma aula, cada turma é de uma forma, cada região é de uma forma."

Hoje Nilce afirma gostar do trabalho, mas relata um certo "desgaste", pois sentese de "mãos atadas" com relação à complexidade dos problemas educacionais. No início, e durante oito anos, conciliou as aulas na rede estadual com a atividade em uma escola particular. Quando voltou a ficar apenas na rede pública, demorou até conseguir uma situação estável. Mais uma vez, o caráter cansativo e a batalha cotidiana do trabalho docente surgem em sua fala sobre a profissão: "quando eu voltei tive que quebrar bloco, como a gente fala... fiquei um pouco nessa escola, passei por outras". No entanto, mesmo reconhecendo a sobrecarga ao relatar seus horários de trabalho, procura não se vitimizar: "a gente acostuma, é bem corrido, mas acostuma".

Branca, loira e de olhos claros, tem postura amigável e, ao mesmo tempo, firme. Fala de maneira clara e articulada, sobretudo quando faz considerações sobre questões pedagógicas a partir de sua experiência. Sua avaliação é de que os alunos chegam "cada vez mais fraquinhos" e de que as famílias não acompanham a vida escolar dos alunos, nem lhe dão o devido incentivo. Diz isso reconhecendo as dificuldades dos pais, que trabalham "feito loucos" e não podem ausentar-se do trabalho para comparecer às reuniões. Para Nilce, é como se a sociedade não reconhecesse o professor como parte dela e sua percepção é de que, de modo geral, as pessoas desconhecem a realidade da escola.

Quanto à categoria, tem uma postura ambígua - que aparece, como se verá mais adiante, na maioria dos entrevistados. Diz não gostar dos sindicatos (mas pondera que no município são mais "atuantes" que no estado) e critica o que chama de individualismo dos professores - faltam-lhes consciência, ações coletivas. No entanto, em outro momento da entrevista, ela atribui a si própria essa característica (o individualismo), quando questionada se falaria sobre os problemas educacionais a um jornalista. Depois de hesitar, diz, parecendo envergonhada, que evita a exposição. "Eu não gosto muito [risos]. Eu sou um pouco assim... ah, eu não gosto de me expor. Aqui é diferente, informal, o que eu falo você vai colocar no papel e não vai ter problema..." Nunca deu entrevistas mas, na situação hipotética de ser procurada por um repórter, 
preferiria não falar. "Hoje não, eu já fui mais... hoje eu tô mais no individualismo" diz, apressando-se em completar: "eu acredito na educação, quero que funcione, faço meu melhor. Já falaram ‘por que você não larga o cargo, faz outra coisa?' Eu digo eu gosto. Ouço muitos colegas desmotivados falando: não adianta, o que que eu vou fazer? Mas acho que se você não fizer sua parte..."

O sentimento de vergonha surge em outro contexto da entrevista, mas não no sentido anterior, que indicava um tom de repreensão da própria atitude. Quando o assunto é mídia, diz sentir-se envergonhada com o modo como os professores são retratados, pois sabe que os outros têm essa opinião sobre o grupo e, consequentemente, sobre ela: "outro dia eu li uma reportagem, era da Veja, não lembro o título. Eu fiquei envergonhada. Dizia que o professor não preparava aula, não dominava a sala, que o professor não tinha vontade de melhorar e muitas vezes era acomodado. Que ia lá, sentava e deixava as coisas acontecerem". A imagem é imediatamente rechaçada: "a gente não vê isso no dia a dia. Se o professor não estivesse com vontade, não iria estudar. Não ia buscar formas diferentes para dar suas aulas, não haveria tantos projetos diferentes nas escolas para tentar melhorar". Por isso, assim como pensa sobre a sociedade em geral, Nilce acredita que a mídia não conhece a realidade da educação.

O descrédito com relação à imprensa (que "nem sempre é favorável”), reflete-se na pouca importância que dá aos meios de comunicação como fontes para acompanhar as questões educacionais. "É mais pelo bate-papo, mesmo... um fala para o outro, que conversa com o outro (...) Nesses horários pedagógicos você é informado [dos novos projetos e políticas]". Nilce relata manter uma boa relação com a coordenação e direção da escola, evitando o desgaste, mas nem sempre foi assim. Antes, batia de frente, mas procura se justificar: "eu já falei, já bati de frente, e aí vem aquela pressão. Você já tem dois trabalhos, sua vida pessoal, e uma pressão de fora que é complicada. Acho que deveríamos ter, sim, um pouquinho mais de consciência como um todo, do grupo. Porque aí as coisas aconteceriam. Mas eu não sinto isso. E sozinho é muito difícil”.

Mas, afinal, Nilce vê algum impedimento para os professores darem entrevistas? Diferente do que acontece no restante da conversa, a pergunta provoca bastante hesitação. "Acho que não... mas.... não sei.... o professor tem um pouco de medo, um pouco de receio. De uma represália, não uma represália, mas de...”. E, após uma longa pausa, completa: “o clima às vezes já é tão difícil... que ele não quer se expor”. 


\section{Rosa}

Rosa concedeu entrevista para esta pesquisa na Sala de Leitura de uma escola municipal no Jaçanã - a mesma de Nilce. Professora de Língua Portuguesa e Literatura, disse que não poderia estar em ambiente melhor. A sala estava toda decorada com peças artesanais e cartazes sobre História da África, resultado do trabalho de uma colega que fez mestrado na área. Rosa tem 47 anos - 12 deles na docência -, é casada e tem dois filhos - sua menina de 13 anos, que estuda naquela escola, acompanhou parte da entrevista, realizada durante o horário de almoço. O outro filho tem 18 anos. Além da rede municipal, concilia aulas no estado, na periferia de Guarulhos, totalizando 45 horas semanais de trabalho.

Ser professora não era um sonho, tanto que entrou tardiamente na profissão. Ela fala com carinho de seus pais, que não tinham escolarização (Rosa conta que aprenderam a ler e a escrever na fazenda) mas faziam questão de que ela estudasse. Aos 60 anos, sua mãe formou-se em uma unidade do Movimento de Alfabetização de Jovens e Adultos - MOVA. Já seu pai era "autodidata", um "faz-tudo": fez até curso de contador na igreja, tocava música de "ouvido". Caçula de quatro irmãos, Rosa foi a primeira de sua família a ter oportunidade de cursar o Ensino Superior, diferente de seus irmãos, que precisaram priorizar o trabalho. Queria ser jornalista, mas seu pai foi contra: “não é profissão de mulher”. Seu pai tinha como referência de mulher jornalista a Glória Maria, que fazia inúmeras viagens para suas reportagens dominicais no programa televisivo Fantástico, da Rede Globo. Acreditava que a ocupação era incompatível com a constituição de uma família. "Ele dizia: vai ser professora, e eu: Deus me livre! Aí fui fazer curso de contabilidade", conta Rosa, rindo.

Decidiu, então, estudar Letras com Licenciatura Plena em uma instituição privada (Faculdades Integradas de Guarulhos - FIG) para ser secretária bilíngue, mas descobriu que o inglês da Faculdade não era suficiente para isso. Terminada a faculdade, estava trabalhando em uma empresa, na área de Recursos Humanos. Dez anos depois, já com 35 anos, era gerente de R.H. quando precisou sair e viu como única alternativa possível a sala de aula. "Falei para meu marido: com essa idade, e dois filhos, vai ser difícil conseguir uma colocação na minha área. Eu trabalhava com R.H., sabia como estava o mercado naquele momento. Falei: quer saber? Vou tentar dar aula, 
meu diploma tá aí!" Doze anos depois, não se arrepende. "Hoje gosto muito do que faço, acho um trabalho gratificante."

Está tentando emplacar um projeto na escola - que já apresentou na Diretoria Regional de Ensino com certa receptividade - de criar turmas separadas por desempenho (segundo ela, para ajudar no desenvolvimento tanto dos que estão acima da média quanto dos que têm dificuldades de aprendizagem). Na comparação entre a situação da rede municipal e estadual, considera a primeira melhor do ponto de vista salarial, de carreira e condições de trabalho; no entanto, o estado oferece uma maior liberdade. "O diretor lá tem uma autonomia maior que aqui. Lá, vou falar em português claro, punição... é uma palavra muito pesada, mas ele tem como resolver os conflitos de indisciplina, brigas. Aqui na Prefeitura você fica meio de mãos atadas."

Com relação à imagem dos professores, Rosa tem a percepção de que a sociedade é "dividida": "parte acha que tudo é papel da escola e tudo é culpa do professor", e a outra parte acredita que as coisas ainda podem mudar. Na mídia, sua impressão é de que tudo é desfavorável, e diz estranhar quando vê na imprensa algo de positivo. "Só quando é dia do professor." Também na fala de Rosa aparece o sentimento de que a realidade da escola não é conhecida fora dela. "Os poucos momentos que temos de voz é nos momentos de greve. E mesmo assim é deturpado o que é falado. O que é jogado para a sociedade é uma coisa, e o que o professor tá vivendo na pele não é bem isso." Por isso, para se informar sobre questões educacionais, privilegia a internet e o site dos sindicatos, ou recorre ao site de buscas Google. Mas também vê telejornal às 6 da manhã e, às vezes, à noite.

É bastante crítica com a forma como os governos tratam os professores, mas diz ser contra greves. Por causa disso, já na época em que estava na empresa, seu marido a chamava de "burguesinha". Porém, Rosa faz a ressalva de que algumas vezes a greve pode ser necessária. Nunca fez greve na rede municipal, mas na estadual, sim. "Foi para lutar por meus colegas que não são efetivos (...) A gente tem que se unir e ajudar esse pessoal. Não tem professor na rede, está faltando muito professor no estado. Se não mudar essa política...” Hoje é concursada em ambas as redes, mas relata que foi muito difícil o período em que atuou como professora eventual: "fui muito humilhada". Os professores que têm vínculo precário, conta, têm que ir conquistando os colegas "com seu trabalho, sua submissão". "Eu senti isso, e sei que ainda tem outros que ainda 
sentem." Em sua escola atual, sobretudo na rede municipal, Rosa considera o relacionamento com a equipe pedagógica "muito bom, muito gostoso". Segundo ela, o diretor e os coordenadores são "bastante companheiros".

Apesar de sua postura avessa às greves, é representante de um dos sindicatos municipais em sua escola. Acompanha as reuniões trimestrais e incumbe-se de repassar as informações aos colegas - apesar de estes não se interessarem muito, na sua avaliação. Diz que participa deste porque o outro sindicato municipal é "muito político", e explica que seu presidente é deputado [na verdade, é vereador]. "O sindicato é do povo, não pode se envolver em política." Quando avalia a categoria como um todo, afirma que o problema é que "infelizmente, cada um olha para o seu umbigo". Esse individualismo não se expressa somente na ação política, mas também afeta o cotidiano da escola. "Não é um grupo unido (...) Se você tem um problema comum, dois ou três dão a cara a tapa, os outros ficam na retaguarda."

Rosa nunca teve situação de interação com jornalistas, mas lembra-se de quando um programa da TV Cultura filmou um projeto do qual ela fazia parte em uma de suas escolas. A ideia de dar entrevistas não parece problemática para ela. Quando questionada se conhece algum impedimento para que os professores falem com a imprensa, não citou nenhuma regra específica, mas afirmou com bastante naturalidade que deve haver impedimento para casos "graves". "O que eu sei é que quando acontece alguma coisa grave, aquela coisa de que não pode ficar se pronunciando, que o diretor meio que...", hesitou, sem completar a frase, e seguiu: "é uma coisa como a que aconteceu numa escola aqui do lado, que está tendo um problema sério. Mas não teria impedimento".

Questionada sobre o lado ruim da profissão, Rosa diz confiante que não vê pontos negativos, "só algumas coisas do sistema, que tem que mudar". Faz questão de reiterar que gosta muito do que faz, acha o trabalho "gratificante". Mais adiante, reconhece que o acúmulo de cargos - necessário pelo baixo salário - não vai continuar por muito tempo. "Mais uns dois anos, acho que não aguento mais." Pouco depois acaba citando um ponto negativo: "às vezes é [a falta de] reconhecimento, da parte política, administrativa". 


\section{Cilene}

Cilene foi uma das quatro pessoas que se dispôs a dar entrevista a esta pesquisa durante horário pedagógico em uma escola estadual de Perus. Foi a primeira a levantar a mão após alguns instantes de silêncio, quando o coordenador pedagógico perguntou durante a reunião de ATPC quem estaria disposto a falar com a pesquisadora. Tem feição séria e, apesar de tímida, fala com firmeza e de forma articulada. É negra, tem 31 anos - dez deles de docência -, casada e com três filhos - de 10,5 e 1 ano e meio de idade.

Nasceu e cresceu em Caieiras (município da Grande São Paulo) e foi a primeira de sua família a fazer Ensino Superior, incentivando muitos primos depois a seguirem o mesmo caminho. Sua mãe era empregada doméstica e seu pai, operário metalúrgico. Outros familiares exerciam funções de faxineiro, caixa de supermercado, atendente de loja, recepcionista. Cursou Licenciatura em Letras, na instituição privada Faculdades Integradas Tereza Martin - FATEMA, mas não pensava em ser professora - o curso era o único que ela podia sustentar com ajuda do salário da mãe. "Acabei fazendo mais por uma questão financeira mesmo, mas depois eu acabei gostando do curso em si." Cilene conta que ela ter se tornado professora é um grande motivo de orgulho para a família: “'nossa, olha, a minha sobrinha é professora'; 'minha neta é professora'. Então, eles tinham mais orgulho do que eu de falar que eu era professora. Ainda hoje ainda têm, só que um pouco menos, porque às vezes eu chego em casa chateada por algumas situações que acontecem, pela situação da Educação como está hoje, você se sente impotente".

Hoje dá aulas de Língua Portuguesa no Ensino Médio, tem cerca de 270 alunos e cumpre 33 horas de trabalho semanais. A média de alunos por turma, no ensino médio de sua escola, é bastante alta: "uma média de 45 , tem sala que tem 42 , tem sala que tem 39; mas tem sala que tem 47 , por exemplo. E tem dia que eu dou uma atividade, na qual eles estão tendo dificuldades; e é assim, todos chamando ao mesmo tempo e querendo atenção, eles ficam desesperados". Sente-se próxima dos alunos adolescentes, com quem diz se dar bem.

Aos 18 anos, havia iniciado um estágio na área e considera suas primeiras experiências na docência traumáticas. Atribui as dificuldades de então ao fato de ter, na época, vínculo precário e ser "muito novinha". "Passei por algumas situações, 
determinados constrangimentos de... por ser eventual, você não ser valorizada, nem pelos professores, pelo corpo docente, no geral, pela direção.” Mesmo doze anos depois, ela acredita que os professores eventuais ainda passam pelos mesmos problemas pelos quais ela passou. "É um lugar de submissão, faz o que os outros mandam e não tem o direito de questionar."

Após essa primeira experiência, saiu da área de educação e, "revoltada", foi caixa de supermercado, depois operadora de telemarketing, até tornar-se bancária. Com o nascimento de seu segundo filho, foi chamada para um concurso que havia prestado e optou pelo setor público por causa da estabilidade e flexibilidade de horários para ficar com as crianças. Mas não foi uma decisão fácil. Já havia prestado um concurso e, mesmo tendo sido convocada, desistiu. Foi uma amiga que lhe convenceu a aceitar da segunda vez em que passou no concurso: "Vai tentar, é diferente ser efetivo; se você não conseguir, o máximo que pode acontecer é você pedir exoneração do cargo e seguir em frente". Aceitou o "teste" e está há seis anos de volta à rede estadual. Como tem os filhos ainda pequenos, não consegue pegar mais aulas em outras escolas, porque não tem com quem deixá-los no período da tarde. Nessa rotina, não é nenhum exagero dizer que não sobra nenhum tempo livre. "Casa e filhos me consomem totalmente."

Considera a categoria dos professores "bem desunida" e diz não ser adepta dos sindicatos dos professores pela forma como conduzem as paralisações (não se sindicalizou, inclusive). "Não sei se essa desunião é por falta de... de interesse, de cansaço, porque o pessoal já está cansado por conta das coisas que vêm acontecendo; ou, se a desunião é por conta dessa divisão das categorias que houve por parte dos governantes”, diz, referindo-se às múltiplas categorias funcionais existentes (“O”, OFA", "L" etc.).

Critica a mídia por não mostrar a realidade das escolas nem do trabalho dos professores, e acaba acessando notícias e informações sobre educação pela internet, por indicação dos colegas. "A mídia mostra uma pessoa despreparada, que larga os filhos da população ao Deus dará, para ir às ruas pedir um aumento ao qual ele não tem direito.” Nunca teve situação de interação com jornalistas na escola. Questionada sobre a existência de impedimentos para entrevistas, Cilene não cita a lei ou outras restrições ela, mesmo, acredita que falaria sem problemas, por gostar de expor sua opinião. Entretanto, reconhece que os professores têm medo dessa situação, e cita diversos casos 
em que os professores foram expostos em reportagens de televisão sem ter suas versões exibidas. "Por exemplo, eu vi uma reportagem, há um mês, de uma professora que foi exonerada do cargo, porque mostrou ela falando um palavrão em uma sala de aula de Ensino Médio. Mas ninguém foi investigar a fundo, o que de fato aconteceu naquele momento."

Além do descrédito da mídia, acredita que os professores receiam outros tipos de represália, mas não se posiciona entre eles. "Eu sou bem bocuda, eu gosto de expor o meu ponto de vista, independente se ele vai incomodar ou não; mas tem professor que tem receio de se expor, ele tem receio que a parte de Gestão, Coordenação, Direção, se indisponha com ele por conta de algum comentário que ele tenha feito; tem muitos colegas assim."

\section{Dalva}

Há 28 anos na rede pública de ensino, Dalva, aos 50 anos, é casada e mãe de dois filhos - um rapaz de 20, que já está na faculdade; e uma filha de 16. Concilia vínculos na rede estadual e municipal, ambos como professora efetiva - na primeira, é inspetora e mora na própria escola, no Jaçanã; no município, dá aulas a turmas no primeiro ciclo de ensino fundamental - na mesma escola em que Rosa e Nilce atuam. Somados, os trabalhos lhe rendem uma carga de quase 70 horas semanais, com aulas a cerca de 80 crianças. Tem postura retraída e desconfiada.

Filha única de empregada doméstica e de um pedreiro, relata uma infância difícil. Seu pai saiu de casa quando ela ainda era pequena. Sua mãe, embora tivesse baixa escolarização, fazia questão de acompanhar de perto e estimular seus estudos. Uma madrinha, que acolheu Dalva e sua mãe quando a menina tinha 9 anos, era professora, tinha uma irmã também professora, um irmão médico e outro, delegado. "Eu via a minha mãe trabalhando feito uma doida em casa de família, às vezes faltava comida ela trazia uns caldos de sopa da casa das pessoas; e eu, já de pequena, eu não queria isso para mim, eu não queria ser empregada doméstica, eu achava que não era para mim; o estudo era o caminho para eu sair dessa situação." Quando se mudou para a casa da madrinha, encontrou "um outro nível" e teve essa certeza. "Era sempre a mais dedicada da turma, ser professora foi uma escolha natural", diz, explicando que tinha 
facilidade em aprender as matérias e já ajudava seus colegas a estudar.

Dalva ressalta as lembranças - ainda muito vivas - de seu encantamento pela escola, pelo capricho com que sua mãe encapava os livros e cuidava de seu material escolar, pela disciplina que lhe era demandada no ambiente escolar. "Sempre fui apaixonada pela escola, a escola para mim era um lugar assim mágico, de descobrir as coisas, de aprender, eu gostava de ir para a escola, dos professores, dos livros; eu lembro da minha $1^{\text {a }}$ Série, do primeiro livro que eu... que a minha mãe comprou, assim, que eu fui junto com ela para comprar, foi a cartilha Caminho Suave, e aquela cartilha eu tenho o cheiro dela até hoje na minha memória." Todo esse capricho e atenção de sua mãe, ela procurou reproduzir na vida escolar de seus filhos - sempre que pôde, pagou colégios particulares. "Eu busquei para eles um estudo melhor."

No ensino médio fez magistério e, mais tarde, curso de Letras na Faculdade Santana, instituição privada. Foi a primeira de sua família a fazer Ensino Superior. Um dos principais problemas da educação hoje, na sua opinião, é a "falta de retenção" e de acompanhamento das famílias: "a escola, antigamente, no tradicional, que eles não gostam que fale, mas ela funcionava; então, a gente não tinha os problemas que nós temos hoje, do aluno não saber, do aluno passar". Essa visão de mundo, que pode ser considerada conservadora, aparece ainda em outros comentários sobre as políticas de redistribuição de renda. "Eu sou contra as pessoas viverem de esmola, viverem de... depender do Governo. Hoje, as pessoas têm muitas facilidades, têm esse monte de bolsa aí, Bolsa-Gás, Bolsa-Família, Bolsa não sei o quê; só que as pessoas não querem sair desse círculo."

O ponto positivo da profissão, responde, é o amor que sente por ela. O negativo é justamente a falta de respeito e valorização, que, ressente, havia na época em que estudava. "Tinha um cuidado, tinha um respeito, tinha uma valorização. Era muito valorizado. Os pais, antigamente, valorizam muito os estudos", diz, acrescentando a esse quadro a participação da mídia, que "derrubou muito a escola". É a sensação de insegurança e ameaça que ela sente das famílias, e não um esperado reconhecimento.

É sindicalizada e diz aprovar a atuação de todos os sindicatos, municipais e estaduais: "fazem muito pelos professores". Quando questionada sobre a forma como vê os colegas da categoria, resume: sofredores. "Enquanto no Japão o professor é tratado como Mestre, recebido até pelo Imperador, pelo rei, pelos príncipes, é venerado; no 
Brasil, o professor é massacrado, entendeu?" Já quando a questão é como a sociedade vê o professor, Dalva também é rápida e incisiva na resposta: inimigos. "E a imprensa ajudou a tirar a nossa imagem de pessoas dignas e decentes que somos, porque somos todos trabalhadores, pais e mães de família, tentando mudar esse país de alguma forma, fazer com que os nossos alunos se tornem cidadãos conscientes, boas pessoas, de boa índole."

Ainda com relação à mídia, Dalva diz acompanhar com bastante interesse tudo o que sai sobre Educação (“O ENEM, o IDEB, o ensino médio como está, como não está; o que o novo Ministro da Educação está falando, as universidades"). Tem, como principal fonte, os jornais que a escola assina (Folha e Estado de S. Paulo), a internet, os materiais que vêm do governo, a televisão ("gosto muito") e os jornais dos sindicatos. Mas vê a imprensa com olhos bastante céticos porque, na sua opinião, nunca mostram a versão dos professores: "tudo que a imprensa fala é rebatendo, batendo: a professora bate no aluno. A professora isso. A professora aquilo. Então, foi isso que foi mostrando um lado negativo da profissão. E aí, hoje, nós apanhamos”. Assim como outros entrevistados, Dalva também ressente uma fissura entre a escola e a sociedade, a mídia: "porque só quem está dentro da sala de aula é que sabe o que acontece numa escola e dentro de uma sala de aula". Mas procura valorizar a persistência dos professores, apesar dos problemas que levantou: "trabalhamos por amor".

Dalva nunca concedeu entrevistas a jornalistas - diz não se lembrar de ter sido demandada para uma - mas, para ela, os professores, como todo funcionário público, não podem fazer isso. "Tem toda uma legislação por trás, não pode em lugar nenhum, prefeitura, estado; eles têm uma assessoria de imprensa para isso". Não soube, no entanto, especificar qual era essa legislação. Diz falar muito sobre os problemas da educação em casa e na Sala dos Professores, mas nunca teve a "pretensão" de levar a crítica para outras instâncias e espaços de debate, como sugeriu a pergunta da pesquisadora. Hoje, mantém uma boa relação com a equipe pedagógica, porque acha necessário "vestir a camisa da Educação, da escola" - deixando entender, com o comentário, que as críticas (ou o conflito) são prejudiciais ao desenvolvimento do ensino.

\section{Alberto}


Alberto é professor mediador, função criada há três anos pelo governo estadual para lidar com os conflitos no ambiente escolar. Solteiro, tem 48 anos de idade e 12 de docência. Formado em Filosofia na Universidade São Francisco, uma instituição privada, entrou na profissão "por acaso", primeiro como professor substituto e hoje como OFA-F (professor contratado, mas com estabilidade). Queria ser seminarista, mas "não deu certo"; diz que seus pais fizeram "mobral" e mesmo ele teve que fazer para completar os estudos primários. Também cursou técnico em Administração, e lamenta não ter seguido a carreira: "não sei o que deu em mim para ser professor, eu poderia estar ganhando de 6 a 8 mil reais".

Mas sua história na docência também é daquelas dos que "foram ficando" até se acostumar. No dia em que terminou seu estágio, a diretora da escola em que ele estava lhe convidou a "eventuar": “você não quer seu meu eventual, menino?'; ah, eu perguntei, 'o que é eventual?'; 'É, o dia que o professor falta, você assume'. Assim, no mesmo dia Alberto já teve sua admissão como eventual. Depois, conciliou o trabalho da escola em Brasilândia com aulas na antiga FEBEM de Pirituba. "O primeiro dia, você sua; o segundo, sua um pouco menos; e no terceiro, você está... não está suando mais".

Acumula o cargo de mediador com a docência em outras duas escolas da rede estadual nas regiões de Perus e Caieiras, totalizando cerca de 50 horas de trabalho semanais e aulas a aproximadamente 200 alunos. Mora em Pirituba, mas sua condição de OFA-F não lhe permite escolher aulas perto de casa. "Basicamente, você só vai para escola longe, você nunca pega perto." Parecendo estar bastante esgotado, falou de maneira confusa e pouco linear sobre seu cotidiano - sobrecarregado com questões que vão de indisciplina à saúde dos alunos. "Aí a mãe deixa a criança parar com a medicação, e não podia ter parado. Uma hora você está atendendo aquele: 'tio, tio' - 'O que foi?' - 'O menino lá, está dando crise'. Aí você corre também.”

Muitos professores pedem igualmente sua intervenção em sala de aula: "o que vinha para a Coordenação, hoje jogam para mim”. Segundo Alberto, os professores acham que o aluno "terrível" não precisa ficar em sala de aula, tem que ficar no corredor. "Não é assim que funciona, não. Tem que mostrar para o aluno que quem manda na sala é ele, não é o aluno. Então, hoje em dia, se você entrar em uma sala, você fica doida, você não vai conseguir, se você falar bem educado... igual aquela outra professora, que estava falando, a de Artes; eu já entrei na sala dela dez vezes, quase; em 
duas, eu fiquei, para ela conseguir dar aula”. Nessa função, deve atuar com o Posto de Saúde, Conselho Tutelar, enfim, a rede de proteção. Mas também nesses espaços reclama da falta de apoio e de resolução dos problemas que costuma encaminhar. "Eu falo para os alunos: Se fosse pelo salário, vocês não iam ter professor. Não iam.” E, diante da pergunta sobre o que ainda os faz continuar, Alberto responde: porque a gente gosta da profissão”.

Ele afirma manter uma boa relação com a Coordenação: "tem que ter um jogo de cintura, também, com a Coordenação da Delegacia de Ensino", diz, referindo-se à antiga denominação das Diretorias Regionais de Ensino. Os cursos para a função de mediador, explica Alberto, acontecem com frequência, ao menos uma vez por mês, mas muitas vezes em locais de difícil acesso.

Assim como Dalva, acredita que os professores não podem falar com a imprensa por impedimentos legais: "nós temos os nossos jornalistas [assessores de imprensa da Secretaria], e eles proíbem, por Decreto-Lei, você não pode falar mal do estado" "37. Além de considerar que haja proibição legal, Alberto também relata pressão dos diretores e de funcionários do estado quando acontece algum problema na escola. Diferente de alguns dos entrevistados que nunca tiveram contato com jornalistas, Alberto já presenciou esse tipo de situação com certa frequência, já que as escolas em que dá aulas costumam estar localizadas em regiões periféricas e muito vulneráveis. As situações de violência que acontecem dentro da escola ou, pelo contrário, extrapolando seus muros, caem no gosto de programas televisivos, sobretudo os sensacionalistas vespertinos, de gênero policial.

Mas, mesmo que pudesse falar, garante que não falaria. "Não gosto de jornalistas." Isso porque, para ele, a imprensa retrata os professores como “despreparados" e distorce o que acontece na escola, porque ignora sua realidade - "eles não aguentariam um dia sequer de uma sala com 47 alunos, que é o que temos. Eu já tive até 67 em uma sala". As notícias sobre educação que interessam, explica, fica sabendo pelo Diário Oficial, “que hoje é online”, e pelas reuniões que faz.

Para ele, o principal problema da categoria é que ela é "desunida". Por isso, diz ser contra greves. "Fiz em 2010, para nunca mais fazer; porque eu fiz, meus colegas da

37 Inúmeros exemplos do que relata Alberto e trechos de sua entrevista foram citados no Capítulo 2, tópico 2.7, sobre os mecanismos burocráticos que impedem a fala dos professores e o acesso dos jornalistas às escolas. 
parte da manhã também, só que o professor da tarde não fez, o da noite não fez, e aí eu fiquei com cara de bobo."

\section{Sandra}

Aos 31 anos, Sandra é professora de Língua Portuguesa concursada e atua nas redes estadual e municipal no Jardim Ângela, Zona Sul de São Paulo - totalizando 64 horas de trabalho semanais e 365 alunos. É bastante articulada e expõe com clareza e firmeza suas opiniões, mas demorou a sentir-se à vontade na entrevista. A coordenadora da escola, de quem ela diz gostar muito, perguntou se Sandra não poderia colaborar com a pesquisa. "Se não fosse a coordenadora pedir, eu não falaria. Estou dando esta entrevista para você, o que eu vou ver disso depois? De que vai adiantar?"

Por esse mesmo motivo, afirma não ter vontade de falar com jornalistas, apesar de nunca ter sido demandada. "Honestamente, não sei [se daria entrevistas, caso fosse demandada]. Eu evitei muito falar com você", disse, referindo-se à pesquisadora. "Tem uma hora que a gente cansa de gritar.” Para Sandra, a mídia camufla o que acontece na escola fazendo parecer que está tudo bem (sobretudo nas propagandas sobre valorização do professor). Livros, a internet e os colegas são sua principal fonte de informação sobre questões educacionais.

Sandra conta que teve de ir à Rondônia, onde tinha família, para cursar um ensino médio de qualidade. Sua mãe era dona de casa e seu pai, pedreiro. "Eu sempre vi no estudo uma saída, e eu me dedicava aos estudos, porque na minha família as pessoas não estudavam muito, por mais que a minha mãe se esforçasse, tentasse fazer estudar, a realidade que envolve a gente não é muito promissora para isso." Ficou lá por três anos e, quando voltou, não conseguiu passar no vestibular de uma universidade pública, apesar de ter atingido a pontuação da primeira fase do vestibular da USP. Trabalhou na área de telemarketing e ingressou no curso de Letras da Universidade Ibirapuera UNIB, instituição privada, "por causa do inglês"; já havia feito curso de comissária de bordo e tencionava entrar na área. Ela faz questão de ressaltar que a docência não foi uma escolha, e sim um acidente. Foi durante o estágio do curso, há 7 anos, que começou a dar aulas e gostou da ideia de seguir na docência.

Começou como eventual - período que diz ter sido muito difícil, sem "nenhuma 
segurança". "Porque como não é efetivo, é aquela coisa: eu tenho que concordar com tudo que ela [diretora] quer. Eu tenho que fazer exatamente do jeito que ela quer. E eu tenho que mostrar o meu serviço independente do que eu tenho que fazer para isso, porque senão ela cessa meu cargo." Depois de três anos, passou no concurso, mas ainda levaram mais dois para convocá-la. Nesse período também ingressou na prefeitura primeiro como contratada e depois, efetiva. Ainda hoje, diz ser uma das poucas professoras efetivas da escola estadual em que atua, e critica a alta rotatividade de docentes, que prejudica a construção de projetos pedagógicos.

Além das aulas, organiza o projeto "Recreio Divertido", com atividades durante os intervalos. Gosta de fazer isso, pois sente que melhora seu convívio com os alunos. Quanto aos colegas, critica-os por sua desunião: "acho que é muito cada um olhando para o seu umbigo". Mas tem boa relação com a diretora e coordenadora na rede municipal: "são referências pra mim". De certa forma, atribui a responsabilidade sobre o estado a que a categoria chegou aos próprios docentes, que pararam de lutar em determinado momento: "grande parte da culpa é dos professores, que não lutaram no momento certo, que pensaram 'não, mas para mim está bom; dane-se, se daqui a 10, ou 5 anos, não vai estar". Não participa dos sindicatos, porque acha que são "vendidos" e não representam, de fato, os professores.

Para Sandra, a sociedade vê os professores como babás, para quem os pais vão largar a criação dos filhos. "Não acho que sejamos reconhecidos, valorizados, não", porém, imediatamente, procura completar: "mas, assim, eu gosto do que eu faço, eu gosto de ser professora, eu gosto do contato com os alunos, eu gosto de ser significativa, de certa forma, para eles, porque a gente é referência em alguma coisa".

Já mais adiante em sua entrevista, Sandra temeu comentar, ainda que genericamente, sobre um caso envolvendo mídia em uma de suas escolas. "Na verdade, na escola, a maioria das coisas, elas são sufocadas." Interrompeu por um instante, e quis saber se o nome da escola seria citado. Diante da negativa, continuou. "Teve casos de... dos alunos fazerem uma muvuca gigante na escola em nome de um professor, numa situação muito, digamos, constrangedora; e apareceu no Facebook. Aí começou aquela coisa [da direção]: olha, a divulgação de imagem é crime. A divulgação de imagem é crime. Os alunos acabaram tirando as imagens que tinham sido divulgadas, e não aconteceu nada, o caso abafou." Sandra explicou que os alunos se manifestavam em 
favor de um professor e contra a gestão da escola que, na opinião dos alunos, teria o punido injustamente. "Chegou até polícia na escola, e morreu o assunto."

A professora relata o clima de medo geral no qual sente estar imersa (assim como seus colegas): "a realidade é muito complicada, porque você trabalha com medo, se você se deixa tomar pelo medo, você nem trabalha, porque você tem medo do seu aluno, você tem medo da sua gestão, você tem medo de perder o seu cargo, você tem... você tem medo de tudo, aí você não é valorizado de nada, de lugar nenhum, ninguém te reconhece".

\section{Elaine}

Elaine tem 48 anos, é divorciada (foi casada quatro vezes), tem seis filhos e dois netos. Foi abordada para entrevista na comunidade de Professores da Rede Estadual do Facebook, grupo que reúne mais de cinco mil docentes e no que Elaine é bastante ativa. Aceitou prontamente dar entrevista e indicar outros colegas de sua escola - Alberto, Cilene e Cristina deram entrevista após Elaine ter levado o tema à reunião pedagógica. Marcou de encontrar a pesquisadora na estação de trem de Perus, e disse que seria fácil reconhecê-la, em suas roupas indianas.

Professora de História com 22 anos de profissão, está perto de se aposentar (espera fazê-lo dentro de três anos), mas diz que a escola é a sua vida. Passou no concurso público em 1998, foi Coordenadora durante nove anos em Caieiras e voltou para a sala de aula há quatro. Nasceu e cresceu em Perus. A escola onde hoje dá aulas já havia sido um barracão, e ela acompanhou de perto seu crescimento - assim como o do próprio bairro, que possuía "pouquíssimas escolas"; por ela passaram três de seus filhos e dois ainda estudam ali. Atualmente dá aulas ao ensino fundamental e médio, a aproximadamente 580 alunos. Fez e continua a fazer muitos cursos de extensão e especialização. Aos 18 anos trabalhava na indústria têxtil, mas então formou-se no Magistério, em Estudos Sociais e História na Faculdades Integradas Teresa Martin FATEMA, cursou especializações na PUC e na Unicamp (à distância) e diz que ainda pretende fazer Pedagogia: "só falta esse". Seu sonho era entrar na USP, mas "nunca deu certo."

Seus pais têm origem simples, mas sempre incentivaram-na a seguir os estudos. 
Seu pai migrou da Bahia, era semianalfabeto, "mas sabia Matemática melhor do que a gente, até pela prática dele". Sua mãe teve mais acesso à educação formal: estudou em um colégio de freiras e, conta Elaine, "fez Francês, Latim, mas nunca trabalhou fora de casa", pois seu pai nunca a deixou. "Era daqueles 'baianão' ignorante, sabe, que nunca deixou mulher trabalhar fora. Mas... engraçado, que comigo, filha única mulher, ele sempre deixou eu ser muito livre; então, eu sempre fazia os cursos que eu queria."

Também começou a faculdade de Ciências Sociais, mas parou por motivos de saúde. Elaine desenvolveu problema respiratório grave por causa de um lixão que havia atrás da escola - ela ajudou a fazer campanha para removê-lo, o que aconteceu definitivamente há três anos. Diz que teve recomendação médica para "diminuir o ritmo" e que por isso acabou interrompendo suas atividades militantes no partido a que é filiada (PCdoB) e no sindicato (Apeoesp).

Por causa de sua socialização militante, já teve contato com jornalistas, mas nunca foi entrevistada sobre a escola ou a educação, de maneira geral. Na única situação, deu seu depoimento a um jornalista durante uma exposição sobre a abertura da vala comum de Perus, episódio da ditadura militar que escolheu como objeto do trabalho final de sua especialização em História, na Unicamp. Entretanto, se fosse procurada, diz que não veria problemas ou impedimentos legais para falar. Só faz a ressalva de que a mídia "exagera", é sensacionalista. De fato, entre todos os professores entrevistados, é aquela que mais citou fontes de informação sobre educação na internet, de blogs a sites oficiais - além de acompanhar as páginas, tem muitos contatos que compartilham reportagens sobre o tema nas redes sociais.

Dedica-se muito aos projetos da escola, mas afirma que se dava melhor com os alunos no passado, pois tinham mais afinidades. Cita, por exemplo, as desavenças musicais. "Hoje a molecada curte um som assim que eu não me adaptei, não... às vezes eu fico criticando: 'ai, esses funks malditos"”. E continua: "eles não conhecem Chico Buarque, não conhecem Caetano Veloso, Janis Joplin, Pink Floyd (...) Mas eles conhecem essas bandas mais novas. É um lixo. Não falo isso para eles, mas eu penso comigo. Então, isso acabou me afastando um pouco mais". Entretanto, ainda diz ser muito próxima da comunidade. "Todo mundo sabe onde eu moro, os pais me param na rua para conversar, para perguntar do filho.”

Elaine se orgulha de conhecer os alunos pelo nome: "eu gosto muito daqui, é 
uma coisa que me faz bem; eu conheço meus alunos pelos nomes, nunca fiz chamada por número." Isso, diz, aprendeu com o próprio Paulo Freire, que teria falado sobre isso em uma palestra na PUC em que ela estava presente, em 1994. "Ele dizia: 'tem que chegar perto do seu educando e às vezes perguntar: Você está bem? Como que você está hoje? Estou te vendo mais triste'. Eu aprendi, e fui fazendo exatamente isso."

Com relação ao passado, sente-se menos valorizada, e ouve dos alunos que eles ganham mais que os professores em seus trabalhos informais. Para ela, a mídia contribui, em grande medida, para a degradação da imagem do professor. Não se refere à imprensa, mas principalmente às novelas e aos programas voltados aos adolescentes. "Acho que a mídia atrapalha bastante essa questão da valorização do professor. Você vê essa novela Rebelde, você vê Malhação, esses adolescentes agressivos, tratando o professor como um mero instrumento de trabalho." Por isso, tem a percepção de que a sociedade pensa que a profissão é importante, mas não a valoriza. Seus alunos, por exemplo, desdenham os professores dizendo que, em seus "bicos", ganham mais que eles.

Elaine já brigou com outros professores por falarem mal de Perus, dos alunos, ou de outros colegas. Diz que isso costuma acontecer com mais frequência com os professores novos, que não são efetivos. "Eles têm uma mania de ficar falando: 'ai, fulano é vagabundo.' 'Fulano é favelado.' Você não vai chamar o meu aluno de favelado, eu moro aqui também. Perus é um bairro feio? Pode até ser, se não está feliz, procura outra escola, lá para Zona Sul, lá para a zona... para... aonde que ele achar que deve.” Conta que não está dando aula para agradar à coordenação e aos outros professores, mas para o aluno aprender. "Na verdade, eu procuro viver bem com todo mundo; mas, às vezes, escapa." Também avalia que a categoria é "desunida": “os professores... a gente é desunido, assim, historicamente; aí o Governo inventa um monte de categoria de professor, e a gente fica mais desunido ainda."

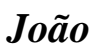

João tem 25 anos, é solteiro e está há quatro anos na rede estadual - leciona Língua Portuguesa ao segundo ciclo do Ensino Fundamental e Ensino Médio. Ainda não teve oportunidade de prestar um concurso - o último aconteceu quando ainda não 
estava formado - por isso integra a chamada "Categoria O", sem estabilidade. É graduado em Letras pela Universidade de São Paulo - onde me recebeu para a entrevista - e encantou-se com a área de educação durante a Licenciatura. Decidiu, então, que faria pesquisa sobre políticas educacionais e estudaria para entrar no mestrado - o que efetivamente ocorreu, meses após ser entrevistado. Já integrava um grupo de pesquisa na USP por meio de bolsa Capes, oferecida a professores da educação básica no Programa Observatório da Educação. Assim, à época da entrevista, acumulava 44 horas de trabalho semanais: 24 na escola, e 20 horas em atividades de pesquisa. De fala tranquila e articulada, acabou por desenvolver análises mais gerais sobre todas as experiências que relatou durante a entrevista.

Filho de mãe comerciante e pai advogado, cresceu num ambiente em que se valorizava a profissão docente. "Tem uma parte da minha família ali que é ligada à esquerda... que... se mostravam não professores profissionais, mas professores nas conversas, na forma didática de apresentar, nas discussões." Também sentiu a cobrança por avançar nos estudos. "Desde o começo da minha escolaridade havia a cobrança de fazer o Ensino Superior, porque tinha condição, e porque isso estava colocado no horizonte para os meus pais; a gente vai aprendendo que o Ensino Superior é o caminho a ser seguido, embora eu discorde um pouco do fato de que todo mundo tem que fazer..." Estudou o primeiro ciclo do ensino fundamental em escola pública, e depois até o fim do ensino médio frequentou uma escola católica. "Uma formação católica, inclusive, com bastante... com um viés bastante social, por incrível que pareça." Ao fim do $3^{\circ}$ ano, estava se sentindo perdido e prestou vestibular para História, Economia, Música. Depois de fazer um ano de Cursinho preparatório, tentou História e Letras, e acabou se decidindo pela segunda. Para cursar a USP, mudou-se de Sorocaba para São Paulo.

Desde que entrou na Faculdade, já queria ser professor. Tanto que, já no segundo ano, começou a dar aulas. Primeiro em uma escola particular em Mairiporã, que recebeu seu currículo se oferecendo para aulas de redação fora da grade horária. "Foi como se tivessem comprado um pacote de aulas, não tinha carteira assinada, direitos trabalhistas, nada". Começou em uma escola de um bairro "bem localizado", Sumaré, mas surpreendeu-se com a falta de estrutura e as dificuldades da escola e dos alunos. "No estado, você sente, é um tapa na cara toda hora, dá um baque; quando chega, desde a estrutura..." Hoje, atua em uma escola de um bairro também considerado 
nobre, o Alto da Lapa. "Parece que eu só pego aula em lugar chique", brinca, "mas, assim como na outra escola, os alunos não são da região, eles vêm do Morro Doce". João explica que estes que conseguem chegar a essa escola tem uma situação econômica melhor. Naquele bairro, conta, tem uma escola que ele chegou a visitar, certa vez, quando foi jogar futebol com os alunos. "É assim, cena de terror, nenhum vidro, aquele prédio feio."

João, assim como Elaine, tem fortes disposições para a militância política. Sindicalizado, chegou a ser representante escolar da Apeoesp, mas afastou-se por ter críticas à forma como o sindicato é conduzido por seus dirigentes. Ex-integrante do movimento estudantil, hoje atua na Consulta Popular - movimento social que faz trabalho de base e formação política para a construção de "um projeto popular para o Brasil". Justamente por frequentar espaços de debates, teve contato com jornalistas e foi procurado algumas vezes para dar entrevistas. Embora ache importante expor opiniões à imprensa, critica os jornalistas por tratarem os temas de maneira superficial e não se interessarem pelo que os entrevistados têm a dizer - seguem pauta predefinida e, para ele, só querem validar a própria tese. Portanto, quando demandado, fala, mas acha "estranho". Tem muita preocupação com os argumentos que vai dar, temendo distorções. Já deu entrevistas ao jornal Estado de S. Paulo e à TV Futura - episódio em que, conforme relatado no Capítulo 2, sentiu-se desconfortável diante da presença de uma diretora. Quando questionado se vê impedimentos burocráticos ou legais para entrevistas, diz que não; mas pondera que pode haver dificuldades que ele não vê, por exemplo, a burocracia escolar barrar entrada de jornalistas que queiram apurar algum problema.

Também já teve problemas com a direção da escola em que atuava, em uma situação de greve (episódio também detalhado no Capítulo anterior). Mas procura não fazer generalizações a respeito da categoria, que acha muito heterogênea - questiona mesmo a validade de chamar os professores de "categoria". Quanto à sociedade, acredita que vê o professor como um coitado e, ao mesmo tempo, salvador.

\section{Maísa}

Maísa tem 48 anos, é casada e cresceu em sítio no sertão de Pernambuco, onde 
viveu até os 30 anos. Relata uma infância sofrida e humilde - onde morava, não havia energia elétrica e precisava caminhar 16 quilômetros para ir e voltar da escola, todos os dias. Veio para São Paulo com o "coração apaixonado", expressão que diz sorrindo. Começou a dar aulas em sua cidade natal, quando ainda cursava o magistério, aos 16 anos. Faltavam professores em sua região, e sua irmã mais velha, também professora, a estimulou a seguir a profissão - em que já completa 32 anos. Seus pais, agricultores, não tinham escolaridade.

Em São Paulo, continuou a dar aulas porque não se encontrava "em outro local que não fosse a Educação". Hoje Maísa é efetiva nas redes estadual e municipal no Jardim Ângela e em Guarapiranga, com um acúmulo de quase 70 horas semanais e cerca de 240 alunos. Assim como Sandra, aceitou dar entrevista a convite da coordenadora da escola, de quem diz gostar bastante. Esta lhe disse que o tema era a voz docente, ao que Maísa respondeu prontamente: “é comigo mesma!". Quando ouve da pesquisadora, por formalidade, que seu nome não será revelado na dissertação, observa: “o meu nome está limpo, e o que eu vir a falar não será nada que venha a comprometer a mim e a ninguém". Mas foi só no decorrer da entrevista que percebeu, um pouco decepcionada, que a pesquisa não tratava da questão das cordas vocais propriamente ditas. É que, com tantos anos de docência, acabou por desenvolver problemas de saúde vocal, chegando a se afastar das aulas por um tempo. Apesar de alegre e expansiva, falou muito pouco durante a entrevista, limitando-se a respostas curtas e diretas, como quem prefere não se comprometer com declarações mais aprofundadas.

Além do Magistério, formou-se em Letras na Faculdade de Ensino Superior de Nazaré da Mata (na época, instituição privada subvencionada), em Pedagogia e fez especialização em Psicopedagogia, na UNIBAN (também privada). Diz amar a profissão. Parecendo sempre celebrar os pontos positivos, afirma que não há "nada $a$ reclamar" sobre os colegas e, numa resposta de tom até protocolar, relata se dar muito bem com todos, sempre.

Sobre a possibilidade de dar entrevistas à imprensa, por exemplo, acha que não existem impedimentos, mas é cautelosa, dizendo que uma entrevista "pode trazer complicações para si própria”. Ela, mesmo, nunca teve experiência com jornalistas. Diz ser alheia à mídia, que não tem tempo de acompanhar, e acaba se informando mais sobre educação por meio dos colegas. Mas acredita que há "pontos, situações, que 
mereciam uma atenção maior, uma defesa maior, para o lado do professor, e não há". Para ela, a atenção acaba se voltando sempre para o aluno. Este é outro problema que levanta: "a gente vive um momento crítico, com essa democracia muito aberta para o aluno, o que não deixa de ser uma coisa boa (...) mas acaba havendo uma interpretação equivocada, por parte de muitas famílias (...) os alunos vêm com uma visão de muito direito, porque tudo eles sabem que é direito dele, 'eu posso isso', 'eu posso aquilo', 'eu posso tudo'; mas, na responsabilidade, eles negligenciam”.

Quando estimulada pela pesquisadora a avaliar os professores como categoria, diz reconhecer que há gente insatisfeita. Entretanto, seguindo sua postura um tanto conciliadora, logo acrescenta: "mas é minoria e acontece em todas as ocupações". Sobre a imagem do professor, comenta apenas que está desgastada. Novamente, um complemento positivo: "mas a gente vai melhorar, eu tenho certeza".

\section{Cristina}

Cristina é introvertida e séria. Fala pouco e dá respostas breves, mas, ao contrário de Maísa, desenvolve opiniões bastante críticas e por vezes pessimistas. Foi uma das professoras que se dispuseram espontaneamente a dar entrevista, quando convidadas pelo coordenador durante horário pedagógico. Tem 45 anos, 20 dos quais em sala de aula, é solteira e não tem filhos. Filha de pais analfabetos, veio sozinha do interior de Minas Gerais para tentar a vida em São Paulo. "O meu pai sempre passava para nós que ele não tinha e não tem nenhuma fortuna... que não vai deixar herança para a gente, em dinheiro; mas ele fazia questão da gente estudar, eu e meus irmãos, porque ele acredita que esse é um bem que não tem preço, que para ele é muito importante, até porque ele não teve acesso, nem ele e nem minha mãe." No entanto, já adulta, quando resolveu estudar e vir para São Paulo, depois fazer Licenciatura, diz não ter tido apoio nenhum: "tive apoio de pessoas que não eram da minha família, eu peitei e fui embora".

Havia feito curso técnico em Contabilidade, mas não conseguiu atuar na área. Começou então a fazer Magistério, mas foi uma ex-patroa, em 1993, que a aconselhou a fazer Faculdade. Formou-se em Licenciatura em Geografia na FATEMA, instituição privada, em 1998. "Aí terminei, e fui batalhar, fui pegar um estágio.” Começou como eventual em Brasilândia, depois Caieiras, e finalmente em Franco da Rocha, ou, como 
chamou, "periferia da periferia". Assim ficou por quatro anos, apesar de morar na Zona Norte, bastante longe dali. "Não aguentava mais viajar todo dia." Hoje é professora efetiva em uma escola estadual de Perus - a mesma de Elaine e Alberto -, onde está há seis anos e tem cerca de 650 alunos de Ensino Médio. Para Cristina, o principal problema hoje é que as classes populares não dão valor à educação, mas sim ao consumo. Isso refletiria na forma como tratam os professores: "muitas vezes como um nada, sem valor nenhum".

Em mais de um momento da entrevista, disse ser infeliz na profissão. "É meu ganha-pão, mas fiz a escolha errada.” Atualmente, diz não estressar mais com situações com coordenação, direção e alunos, mas não foi sempre assim. Reclama que já foi muito perseguida e evita envolver-se em outras atividades. Em uma outra escola, na época em que ainda era eventual, teve problemas com uma diretora. "Ela questionava o meu jeito de trabalhar, e isso porque eu reclamei, reclamei, assim, do desamparo que a gente vivia lá.” Depois do episódio, decidiu sair daquela escola.

É sindicalizada, mas não acompanha os assuntos sindicais. Quando questionada sobre o que pensa da categoria de modo geral, hesita: "ah, é uma categoria, não sei se é... dizem que é a categoria; mas é uma categoria que deixa muito a desejar, porque muitos agem de acordo com o que o sistema quer, com o que o Governador, a Secretaria da Educação e a corja lá querem”. Também acha que não há união entre os professores, principalmente na hora de lutar pelos seus direitos. Pensa que deveriam "ir à linha de frente", porque, em sua opinião, os representantes dos sindicatos estão em posição confortável e não lutam pelos interesses da maioria. Mas apesar de sua fala parecer combativa, mostrou-se, em geral, bastante desmotivada: "não tenho mais ânimo para ficar me dedicando muito, preparar aula. É uma falha? É, mas...”

Cristina ressente o fato de que articulistas e pessoas que emitem opinião na mídia não conhecem a realidade da escola e, ainda assim, culpam o professor ${ }^{38}$. Acompanha vários programas de TV, principalmente telejornais e se diz leitora assídua de revistas de Geografia, que assina. Nunca deu entrevistas por não ter sido convidada a falar, mas acha que não falaria caso fosse questionada. "Para não arrumar confusão, eu preferia ficar na minha, não me manifestar." Isso porque, acredita, existe um impedimento legal: "funcionário público não pode dar entrevista, é proibido". Lembra-

38 O caso em que se sentiu indignada com a postura do colunista Gilberto Dimenstein durante uma palestra, por exemplo, foi relatado com mais detalhes no Capítulo 2. 
se de certa vez em que equipes de TV estiveram na escola, em 2007, e a direção não permitiu que os professores falassem por ser uma situação negativa.

Cada professora e professor entrevistado possui uma história de vida única e passou por processos de socialização diversos que produziram, em cada indivíduo, determinadas disposições - maneiras de ser, de sentir, de ver, de agir, de apreciar e de pensar. Mas como esse "patrimônio" foi formado - ou, como questiona Lahire - como a herança chegou ao herdeiro?

O autor distingue três modalidades de socialização que incorrem nesse processo de subjetivação da realidade: pode se dar por (1) treinamento ou prática direta; (2) pode ser resultado de um efeito mais difuso da ordenação ou da organização de uma "situação", uma "socialização silenciosa"; (3) ou, ainda, pode assumir a forma de inculcação ideológico-simbólica de crenças (valores, modelos, normas), que procede por inculcação implícita (difusão por impregnação ou habituação) ou explícita (didática) de maneiras de ver e dizer o mundo (LAHIRE, 2004, p. 334-335).

É sobretudo com a segunda forma descrita por Lahire, uma socialização difusa, que lidamos nesta análise ao tratar do modo como os professores formam suas disposições ou predisposições para o debate ou para o recolhimento. Isso não quer dizer que uma composição das três maneiras não surja aqui e ali de maneira insidiosa.

Com os perfis, procuramos reconstituir algumas das principais condições difusas, o "paralelogramo de forças" internas e externas a que cada um dos docentes entrevistados foram e/ou estão submetidos e cujo contexto mais amplo já pudemos descrever no capítulo 2. Dessas histórias, sobressaem-se alguns aspectos comuns, elementos recorrentes que podemos agrupar em três eixos: aqueles que dizem respeito a (i) condições socializadoras; (ii) às condições administrativas e (iii) à condição identitária. A partir desses três eixos buscaremos, a seguir, descrever as características que unem ou, em alguns casos, diferenciam essas histórias.

Com relação às condições socializadoras (i), podem ser observadas características da origem social dos professores, suas famílias, a trajetória escolar, condições de trabalho e relações interpessoais. Nove dos dez casos trazem histórias de famílias que possuíam baixa ou nenhuma escolarização, mas que investiram com os 
meios a seu alcance na educação escolar das filhas - as mães que assinavam os cadernos de lição, tratavam com capricho o material escolar, cobravam bom desempenho na escola e diziam, como disse o pai de Cristina, que encaravam a escolarização dos filhos como o único bem que poderiam lhes transmitir. Lutando contra "essa realidade que envolve a gente", nas palavras de Sandra, que, não é "promissora" para os estudos, ou seja: não permite a dedicação de tempo, investimento material e, sobretudo, dificulta a transmissão de capital cultural no seio familiar.

Ao contrário de João, que teve uma origem mais favorecida e percebe ter adquirido o gosto pelas discussões nas conversas dentro de sua família, mais escolaridade e mais politizada, as professoras entram em contato com o universo escolar e buscam, ali, insumos para superar as difíceis condições de seus pais. Nesse caminho, surge o encantamento pela escola e, também, forma-se um feixe de condições que acabam por levar as jovens à docência. A "escolha", como se pode depreender dessas histórias, foi uma questão de sobrevivência - e, portanto, nem pode ser considerada tão escolha assim, como deixam transparecer vários dos depoimentos - mas, na maior parte dos casos, representou ascensão social inequívoca para aquelas famílias.

Porém, embora represente melhora de vida com relação às suas origens, a docência não significa uma ruptura nessa trajetória de luta por sobrevivência. Várias expressões destacadas ao longo dos perfis revelam um cotidiano marcado por lutas, um “campo de batalha" onde é preciso "quebrar bloco" e "suar". Também aí surgem marcas não só das condições extenuantes de trabalho, mas também de uma realidade opressora, com seus "baques", "tapa na cara", "ameaças", em que é preciso "bater de frente" etc. "Nós apanhamos" e há um clima de "medo geral" - resumem Dalva e Sandra, respectivamente. Mas tais posições não se traduzem em posturas combativas e de questionamento, pois, na "leitura de jogo" feita por esses professores, não há instrumentos, isto é, condições para se ganhar a batalha: "estamos sozinhos", "de mãos atadas", com o sentimento de estar "impotente" e de viver um "desemparo". A estratégia frente a isso, que algumas vezes chega a ser verbalizada, é que, da forma como as coisas estão, não vale a pena criticar, combater. Mais uma vez, a premência é da luta pela sobrevivência e, neste momento, esta parece requerer o recolhimento, a autopreservação. Parecem se subjetivar pelas experiências de constrangimento.

As únicas vozes dissonantes nesse aspecto são as de João e de Elaine que 
reúnem, simultaneamente, duas condições não observadas nos outros casos. Em primeiro lugar, apesar das diferentes trajetórias e origens sociais, Elaine e João passaram por forte socialização no campo da política e da militância que os inseriu em uma rede de relações onde o debate, a crítica e a denúncia são valorizados. Eles são, por exemplo, os únicos que já passaram por situações de entrevista em que foram consultados enquanto professores. Os dois ainda passaram por uma formação política com valores de esquerda que apontam para a necessidade de luta por mudanças da realidade. A outra condição que ambos têm em comum, ainda que também a partir de trajetórias distintas, é a de terem frequentado instituições públicas de renome, em que puderam se dedicar à pesquisa ou ter acesso a uma formação acadêmica mais sólida, confirmando-se minoria no quadro da situação de formação docente apresentado no Capítulo 2.

De fato, como se depreende dos outros perfis, a inserção no Ensino Superior foi feita em instituições privadas de controvertida qualidade e de forma precária (o "inglês não era bom", ou "suficiente", por exemplo), e as professoras ressentem a dificuldade de aplicar os conhecimentos adquiridos na faculdade. Ainda assim, procuram valorizar o que encontraram nos cursos ("mas era muito boa a grade", "o curso foi muito bom"), já que o diploma representou, como já mencionado anteriormente, um grande ganho de status em suas famílias. Assim, não se pode dizer que as duas condições - formação acadêmica mais sólida e militância política - formam, sozinhas, as condições determinantes para a participação no debate público; mas, conforme os casos de Elaine e João sugerem, proporcionam certa segurança subjetiva e formam disposições que a favorecem, ainda que com dificuldades.

Também é possível observar as marcas das condições administrativas (ii) nos perfis apresentados: o modo como a escola e o Estado se estruturam traduz-se em sentimentos, percepções e imprimem sensações na pele dos professores entrevistados. É assim que as professoras relatam o período em que possuíam contratos temporários: "fui muito humilhada", era muita "submissão", "senti isso na pele". A possibilidade de suspensão arbitrária do vínculo de trabalho estava colocada o tempo todo e, por mais que hoje a situação de muitas delas seja outra - oito delas são concursadas e seu cargo é efetivo -, a persistência do problema que ainda afeta os colegas mantém essa memória muito viva (é o caso ainda de cerca de metade da rede estadual, como já exposto no Cap. 2). 
Além disso, fazendo uso das ideias de Berger e Luckamnn (2011), temos que é durante o processo de socialização profissional que se formam "compreensões tácitas" a respeito do que se pode ou não fazer no exercício da profissão, e são adquiridas rotinas e "colorações afetivas" a respeito da atividade. Ora, em um cotidiano marcado por insegurança e ameaças, reiteradas em um longo período de tempo e em diversas escolas por onde esses professores passaram, trata-se de um dolorido aprendizado sobre os limites da sua atuação.

A existência de dispositivos legais e administrativos restritivos - o antigo Estatuto do Servidor, mas, também, circulares, memorandos, comunicados - contribui ainda para a formação de regras tácitas que, transmitidas entre os professores e a partir dos órgãos públicos e gestores escolares, aparecem naturalizadas e subjetivadas nos perfis apresentados na forma de servidor "não pode" falar com a imprensa", "é assim", "está na lei". Entre os professores que afirmaram existir impedimento legal para a expressão - Dalva, Alberto e Cristina falaram de modo mais explícito - nenhum deles soube especificar de que norma se tratava. Tem-se também a percepção de que na escola "as coisas são sufocadas", o "assunto morre", a partir de ordens por vezes da gestão da unidade (como no caso relatado por Sandra, quando afirmaram que a divulgação de imagens nas redes sociais "é crime") ou pela ação de um aparato de comunicação do estado, com seus assessores de imprensa (que, como no relato de Alberto, vêm "com a vara verde" quando algo passível de sensacionalismo midiático acontece na escola).

Por último, pode-se analisar os perfis apresentados neste capítulo sob a perspectiva da condição identitária dos docentes (iii), tópico que merece aprofundamento. Identifica-se na fala dos professores uma tensão entre a identidade atribuída a eles e a identidade conquistada ou reivindicada por eles.

Quando falam sobre o modo como a sociedade vê o professor, os entrevistados descrevem quase em uníssono o quadro de desvalorização apresentado nos capítulos precedentes: veem-nos como "despreparados", “um nada, sem valor nenhum", "falta respeito" e, sobretudo, "ninguém reconhece". Por outro lado, e imediatamente após descrever essas imagens e representações, os professores acrescentam seus pontos de vista: "a gente gosta da profissão", exerce-a "por amor", apesar de tudo "gosto de ser significativa". 
As professoras contam como são motivo de orgulho na família, e como a entrada na docência representou expressiva melhora de vida em comparação a seus pais. Como todos podem considerar isso ruim? A defesa da profissão e a resignação, ou minimização dos problemas, passa a ser um modo de autodefesa identitária ("mas a gente acostuma", depois já "não sua mais", é duro, "mas é gratificante”). A situação também produz a percepção de que as pessoas que criticam não conhecem a realidade da escola, "camuflada" e "manipulada" pela mídia, nas palavras dos relatos.

Esse processo tem a ver com o próprio processo de formação das identidades, que também pode ser analisado em duas dimensões: a) o modo como ele é vivido pelos indivíduos e, de maneira mais ampla, b) o modo como ele acontece nas sociedades contemporâneas.

Assim como as disposições, a identidade é "produto das sucessivas socializações" (DUBAR, 2005), ou, dito de outra maneira, "formada por processos sociais" (BERGER; LUCKMANN, 2011), de tal modo que o indivíduo jamais a constrói sozinho: "ele depende tanto do juízo dos outros quanto de suas próprias orientações e autodefinições" (DUBAR, 2005). Mais uma vez, este processo de construção de um social subjetivado nos diz muito sobre a relação dialética entre a realidade subjetiva e a objetiva, pois ela resulta da interação do organismo, da consciência individual e da estrutura social:

Essas maneiras de identificar são de dois tipos: as identificações atribuídas pelos outros (o que eu chamo "identidade para outrem") e as identificações reivindicadas por si mesmo ("identidades para si"). Pode-se sempre, com efeito, aceitar ou recusar as identidades que lhes são atribuídas. Pode-se identificar-se de modo diferente daquele que é praticado pelos outros. É a relação entre esses dois processos que está no fundamento da noção de formas identitárias. (DUBAR, 2009, p. 14)

No processo de formação identitária, portanto, ocorre a atribuição da identidade pelas instituições e pelos agentes diretamente em interação com o indivíduo; estaríamos diante do momento incorporação de uma identidade, de uma "interiorização ativa", pelos próprios indivíduos, de uma subjetividade vivida pelos próprios indivíduos/professores. 
Auxiliando-nos em nossa reflexão, Dubar recusa em sua conceitualização a distinção entre identidade individual e coletiva, e propõe que

as identidades sociais e profissionais típicas não são nem expressões psicológicas de personalidades individuais nem produtos de estruturas ou de políticas econômicas que se impõem a partir de cima, elas são construções sociais que implicam a interação entre trajetórias individuais e sistemas de emprego, sistemas de trabalho e sistemas de formação. (DUBAR, 1997, p. 239)

Ambos os processos acima mencionados utilizam, em seus mecanismos, as categorias socialmente disponíveis, que são os "recursos identitários". Estes podem ser “capacidades de linguagem, reservas de palavras, expressões, referências que permitem pôr em ação estratégias, mais ou menos complexas, de identificação dos outros e de si mesmo" (DUBAR, 2009, p. 71), sendo inseparáveis das "capacidades relacionais que permitem a descoberta dos outros, a gestão das cooperações e dos conflitos com eles" e também de "competências biográficas, aprendizagem de si, colocação em narração das identificações passadas que permitiram a construção da identidade pessoal”.

Segundo o autor, portanto, é somente pela e na atividade com os outros que um indivíduo/professor pode identificar-se, subjetivar-se, aceitando ou mesmo recusando as definições que recebe dos outros e das instituições. Apoiando-se em Robert Merton, Dubar esclarece que o princípio da predição criativa realiza "uma modelagem do indivíduo a partir da imagem que os outros têm dele e da definição que dão dele”, num complexo processo de negociação identitária.

Ou seja, pelo que identificamos nos perfis, a tensão relativa ao modo com o qual os docentes definem a si mesmo e à categoria e ao modo como se percebem definidos pela sociedade deixam marcas em suas maneiras de ser. Nessa análise, a dimensão profissional é um aspecto fundamental a ser considerado. Isto porque o trabalho permanece "central no funcionamento econômico, bem como na estruturação social e no desenvolvimento psíquico" (DUBAR, 2009, p. 128), um “cacife para o reconhecimento de si". O sentido que atribuímos ao nosso trabalho é um componente importante de nossa identidade/subjetividade e tem a ver com a "situação de trabalho, ao mesmo tempo a atividade e as relações de trabalho, o autocomprometimento com a atividade e 
o autorreconhecimento pelos parceiros (notadamente os que julgam o resultado)" (p. 127).

Sabe-se que o modo de o indivíduo identificar-se sofreu significativas mudanças ao longo da História. Não é sem propósito que em A Crise das Identidades (2009), Dubar analisa as mudanças de ordem sociológica ocorridas nas últimas décadas nos campos da família (vida privada), do trabalho (vida profissional), da esfera política e religiosa (vida pública ou simbólica) e defende a tese de que um movimento histórico, "ao mesmo tempo muito antigo e muito incerto", provoca a "passagem de um certo modo de identificação a outro" (p. 14). Apoiando-se em análises de processos de longa duração de Elias (processo civilizador), Weber (processo de racionalização), Marx e Engels (processo de libertação e consciência de classe), Dubar identifica a crescente preeminência do $E u$ sobre o Nós, dos vínculos "societários" sobre os "comunitários", ainda que estes permaneçam na vida social. Os segundos "supõem a crença na existência de agrupamentos chamados 'comunidades', consideradas como sistemas de lugares e nomes pré-atribuídos aos indivíduos e que se reproduzem de modo idêntico através das gerações”. Os primeiros "supõem a existência de coletivos múltiplos, variáveis, efêmeros, aos quais os indivíduos aderem por períodos limitados e que lhe fornecem recursos de identificação que eles administram de maneira diversa e provisória" (p. 15).

O momento histórico e as mudanças na configuração das formas sociais têm impacto sobre a maneira como as identidades/subjetividades são forjadas, provocando o processo de "crise das identidades"39. A identidade do indivíduo emerge, então, "por meio da intersecção e combinação e consequentemente por meio de conflito com outras identidades" ${ }^{\prime 40}$ (BECK; BECK-GERNSHEIM, 2002, p. 26). A emancipação feminina, o individualismo familiar e os desafios identitários da família, a modificação das identidades sexuadas, enfim, apontam para uma crise do antigo modelo, sem determinar o estabelecimento de outro. O que é inédito são os novos arranjos, "combinações inéditas de formas identitárias", nos termos de Dubar, e portanto a pluralidade dos

39 Dubar (2009, p. 20) assim define a noção de crise aplicada à identidade: "a exemplo das crises econômicas, as crises identitárias podem ser pensadas como perturbações de relações relativamente estabilizadas entre elementos estruturantes da atividade (produção e consumação, investimentos e resultados etc.). A atividade de que se trata aqui é a identificação, isto é, o fato de categorizar os outros e a si mesmo".

40 No texto original: "identity emerges through intersection and combination and thus through conflict with other identities". 
modos de vida.

Para os interesses desta reflexão, cumpre ressaltar que a tese apresentada por Dubar defende que tais crises estão no cerne da construção da "identidade pessoal", "sempre frágil e inacabada, que é a construção de um sujeito mergulhado numa forma social de dominante 'societária"'. Mais precisamente, construir uma identidade pessoal parece ter sido imperativo aos professores entrevistados, para o que tiveram que recorrer a formas identitárias nos diferentes campos de sua vida - político e religioso, da família, do trabalho. Esse é um dos aspectos mais marcantes do momento que vivemos - e que os autores alemães Beck e Beck-Gernsheim (2002) classificam como Segunda Modernidade $^{41}$ : o produto dessa complexa socialização é um processo de individualização dos modos de vida cada vez mais intenso.

Para esses autores, os principais teóricos da sociologia (de Marx, passando por Weber, Durkheim e Simmel, a Parsons, Foucault, Elias, Luckmann, Habermas e Giddens) variam suas abordagens com narrativas pessimistas ou otimistas com relação aos impactos desse processo para a sociedade ou individualidade, mas todos concordam que 1) esta é uma característica de sociedades altamente diferenciadas; e 2) não representa perigo à sua integração, ao contrário, a torna possível (BECK; BECKGERNSHEIM, 2002) ${ }^{42}$.

Mais uma vez, apoiando-se em Elias (2006), afirmaríamos que a socialização e a individualização de um ser humano são "nomes diferentes para o mesmo processo". A possibilidade do individualismo - ou "da escolha real entre realidades e identidades discrepantes" - está diretamente ligada a essa situação: “o 'individualista' surge como um tipo social particular, que tem pelo menos a possibilidade de migração entre muitos mundos exequíveis e que construiu deliberada e conscientemente um eu com o 'material' fornecido por um grande número de identidades que estavam ao seu alcance" (BERGER; LUCKMANN, 2011, p. 218).

É característica dessa segunda modernidade, portanto, que o indivíduo tenha se tornado, pela primeira vez na história, "unidade básica da reprodução social" - o

41 São algumas das características dessa segunda modernidade, na visão dos autores: declínio da ordem social do estado nacional, das ideias de classe, etnicidade e da família tradicional.

42 No texto original, em inglês: "the red thread running through them all is that individualization a) is a structural characteristic of highly differentiated societies and b) does not endanger their integration but actually makes if possible)". 
individualismo foi institucionalizado, a individualização é compulsória e as pessoas estão condenadas a ela (BECK; BECK-GERNSHEIM, 2002). Mas isso não quer dizer que essa unidade básica esteja desvinculada do "social". A própria possibilidade do desenvolvimento dessa "moldagem e da diferenciação especiais das funções mentais" (ELIAS, 1994, p. 27) que chamamos de individualidade só é possível para pessoas que crescem num grupo, numa sociedade. Prova disso, lembra Elias, é o fato de que até o tipo de individualidades também se modifica com o tempo: "a sociedade não apenas produz o semelhante e o típico, mas também o individual".

Auxiliando-nos em nosso argumento, Beck e Beck-Gernsheim, bem como Elias, afirmam que essa individualização é vivida de maneira inexorável. "Os indivíduos se descobrem, cada vez mais, diante de um número crescente de opções. Não apenas podem, como devem ser mais autônomos" (1994, p. 102) - e, quanto a isso, não têm opção. Essa é uma experiência coletiva, cujo desenrolar segue certa forma padrão, esquema. Isso pode não se aplicar a qualquer tipo de sociedade em qualquer momento de desenvolvimento (embora uma característica, a urbanização, seja apontada como necessária), mas designa, certamente, uma tendência à medida que a modernidade avança. E são novas as exigências societárias, advindas dessas configurações: "construir sua identidade pessoal, ser si mesmo, realizar-se, ser competente e performativo etc.”, o que acaba por produzir efeitos desestabilizadores sobre as subjetividades (DUBAR, 2009, p. 258).

Todo esse quadro permite, finalmente, compreender outro forte aspecto da condição identitária dos docentes. Ao analisar o material verbal coletado, percebemos a predominância de uma percepção dos professores sobre o “individualismo" da categoria, característica que, em seu sentido negativo, sentem como uma das principais marcas da docência hoje. São "desunidos", "cada um olha para seu umbigo", foram expressões que apareceram em suas variantes em nove das dez entrevistas. Esse tipo de percepção vai ao encontro do exposto no Capítulo 2, em que foram abordadas as questões e condições para a ação coletiva que estão postas hoje; mas, conforme a reflexão desenvolvida até aqui, a percepção de si individualizado não implica que os docentes estejam de fato apartados um do outro em seu cotidiano. Pelo contrário, é precisamente nessa rede de relações que se formam as disposições para o recolhimento do debate público, a transmissão de regras e compreensões tácitas; é também nos colegas que os professores buscam fonte para o reconhecimento de si, reconhecimento 
este negado pela mídia e pela sociedade, de maneira geral; e, com o descrédito que atribuem à mídia, é entre os colegas, ainda, que os professores falam sobre os problemas educacionais e tomam conhecimento sobre as principais notícias da área.

Quanto mais complexa a configuração em que está inserido, mais o indivíduo tende a construir uma percepção de si individualizado, perdendo a noção do jogo (metáfora construída por Norbert Elias para conceituar as relações humanas). Para Elias (1994), o individualismo subjetivamente instituído acaba por levar a uma fragmentação da estrutura política da sociedade cada vez mais intensa, à sua subpolitização, mas também à despolitização da política nacional. Se, por um lado, a situação cria dificuldades para a formação de consensos, importantes para a ação coletiva, também é verdade que o envolvimento político aumenta no microcosmos, bem como "a sociedade subpolítica é governada a partir de baixo em cada vez mais questões e campos de ação". De qualquer forma, os próprios autores alertam para o fato de que

qualquer generalização que procure compreender a individualização nos termos de um extremo ou outro - autonomia ou anomia - abrevia e distorce essas questões com as quais nos confrontamos aqui. Essa sociedade é caracterizada por formas híbridas, contradições e ambivalências (que dependem de condições políticas, econômicas, familiares). Além disso [...] caracteriza-se pela biografia do tipo "faça-você-mesmo", que - a depender da situação econômica, qualificações educacionais, estágio da vida, situação de família, colegas - pode facilmente se transformar em uma "biografia colapsada" [breakdown biography]. (BECK; BECK-GERNSHEIM, 2002 , p. 7$)^{43}$

Ainda de acordo com os autores de Individualization, as liberdades adquiridas nesse estágio de desenvolvimento da sociedade são, na realidade, "liberdades precárias". Pelo constante risco a que estão submetidos, devido às mesmas características estruturais que lhe conferem possibilidade de liberação, nossos professores, assim como qualquer outro indivíduo, estão “condenados à atividade". Suas falhas são consideradas de sua responsabilidade, assim como seu sucesso. Ao mesmo

43 Do original: "Any generalization that seeks to understand individualized society in terms of one extreme to other - autonomie or anomie - abbreviates and distorts the questions that confront us here. This society is characterized by hybrid forms, contradictions, ambivalences (dependent on political, economic and family conditions. It is also characterized [...] by the do-it-yourself biography which depending on economic situation; educational qualifications stage of life, family situation, colleagues - can easily turn into a 'breakdown biography"'. 
tempo, e esse é também elemento da individualização, a "life of one's own" é uma vida "reflexiva", que envolve o processamento do contraditório, diálogo, negociação, o estabelecimento de compromissos, distanciamento dos papéis. A individualização é um processo ambivalente, da ameaça de exclusão à possibilidade de emancipação, pois abre caminhos para a construção de projetos de vida e de "resistência às etiquetagens, à injustiça ou à designação para um destino" (DUBAR, 2009, p. 218).

\subsection{A Desvalorização como Estigma}

Ainda que relatados de forma breve, é possível observar que os depoimentos mostraram-se bastante similares entre si. Verificamos como os professores, reconhecendo as características que lhe são atribuídas pela sociedade em geral e pela mídia, em particular, adotam uma posição de autodefesa e recolhimento. A "vergonha" relatada pelos professores diante das imagens negativas indicam o alto grau de desconforto gerado pela situação. Falar das precárias condições de trabalho e das deficiências que os docentes atribuem, senão a si próprios, ao seu grupo, é um procedimento que acaba por "minar" uma autoimagem.

Temos, aqui, dois processos que podem ser compreendidos de forma articulada: por um lado, a) a generalização das críticas ao professor, operada pela mídia e percebida por estes; e, por outro, b) a estigmatização do grupo, que os atinge também individualmente.

Norbert Elias e John Scotson (2000), em um estudo sobre as relações entre estabelecidos e outsiders de uma pequena cidade na Inglaterra, auxiliam-nos na análise sobre as experiências de estigma vividas pelos professores. Os autores mostram como o estigma social imposto por um grupo mais poderoso a um menos poderoso "pode penetrar na autoimagem deste último, e, com isso, enfraquecê-lo e desarmá-lo". A pesquisa em questão indicou como esse efeito paralisante pode, por algum tempo, "entravar a capacidade de retaliação" do grupo mais fraco, bem como "sua capacidade de mobilizar as fontes de poder que estejam a seu alcance”. As conclusões dos autores 
sobre a "mecânica"44 da estigmatização só foi possível mediante um exame rigoroso da configuração específica que os dois grupos formavam entre si, e "do papel desempenhado pela imagem que cada pessoa fazia da posição de seu grupo entre outros e, por conseguinte, de seu próprio status como membro desse grupo" (ELIAS; SCOTSON, 2000, p. 25-26).

Assim sendo, a partir do estudo da configuração que forma a vida dos professores, poderíamos afirmar que a atribuição de falhas e também de qualidades positivas aos professores é muito próxima à relatada por Elias e Scotson. Eles lembram que esse é um fenômeno universal. É comum a dinâmica em que grupos de maior visibilidade, que tenham sucesso em afirmar seu status superior, silenciam aqueles que discordam, atribuindo-lhes termos depreciativos e infamantes, ou algum boato vergonhoso. Observamos que a dificuldade em revidar, conforme apontam os autores, acontece porque, embora sintam-se pessoalmente inocentes das afirmações e censuras, os professores não conseguem livrar-se da identificação com o grupo estigmatizado (ELIAS; SCOTSON, 2000, p. 131).

Isto é, não conseguem revidar, ainda, porque até certo ponto a consciência dos infamados está ao lado dos detratores, em um processo de assimilar, para si, as características degradantes atribuídas a seu grupo. As falhas observáveis de alguns membros do grupo docente lhes são, também, automaticamente aplicadas, ou "emocionalmente transferidas para todos os seus componentes", mesmo que não possam aplicar-se pessoalmente a eles. As expressões degradantes proferidas parecem exercer certo poder sobre os professores difamados, já que em sua consciência por vezes concordam com a opinião que fazem de seus colegas, ou seja, de eles próprios - uma concordância silenciosa que lhes paralisa a capacidade de retaliar e de se afirmar. Não se escapa, nessa situação, da estigmatização grupal, da mesma forma como não se escapa, individualmente, do status inferior de seu grupo.

A noção de estigmatização abordada por Ervin Goffman (2008) também trata da transferência de crédito ou descrédito de uma condição para um grupo e pode, ao menos

44 Elias (2000) aponta que o uso de palavras como "mecanismos" ou "armadilha" indicam que configurações como essa exercem um certo grau de coerção sobre os indivíduos que as compõem. $\mathrm{O}$ âmbito das decisões do indivíduo é limitado por essa configuração que, sob muitos aspectos, têm uma força coercitiva, "ainda que esse poder não resida fora dos indivíduos, como em muitas vezes se leva a crer, mas resulte meramente da interdependência entre eles". Para Elias, "somente compreendendo melhor sua natureza [dessas forças coercitivas] é que poderemos ter esperança de adquirir algum controle sobre elas". 
em parte, ser-nos útil na análise que fazemos aqui da desvalorização do professor no debate público. É assim que, por possuir características “desacreditáveis”, a categoria tem atribuída para si a responsabilidade de problemas educacionais que poderiam facilmente ser imputados a outros "vilões", tais como subfinanciamento das políticas educacionais, má gestão, falta de estrutura ou outras questões sociais.

Da mesma forma que Elias, Goffman (2008, p. 116) propõe a articulação relacional entre indivíduo e sociedade para explicar o processo de estigmatização, por meio da dinâmica de formação das identidades e/ou subjetividades: "as identidades social e pessoal são parte, antes de mais nada, dos interesses e definições de outras pessoas em relação ao indivíduo cuja identidade está em questão" e, por outro lado, "a identidade do eu é, sobretudo, uma questão subjetiva e reflexiva que deve necessariamente ser experimentada pelo indivíduo cuja identidade está em jogo". O estigma, de acordo com sua definição, é "a situação do indivíduo que está inabilitado para a aceitação social plena" (p. 7). Entre os efeitos possíveis desse fenômeno está o descrédito; também a vergonha, a insegurança, o afastamento e o encobrimento são sentimentos e estratégias possíveis ao indivíduo estigmatizado. Resta-lhe a manipulação de sua "informação social", conceito usado por Goffman para definir a "informação que o indivíduo transmite diretamente sobre si" (p. 8). Ora, diante do forte quadro de desvalorização e das condições expostas até aqui, a melhor manipulação da informação social que o professor parece fazer no momento é justamente encobri-la, evitando a exposição.

Goffman (2008, p. 17) também indica que o estigmatizado pode "concordar" com a opinião mais geral a seu respeito - se não tomando as críticas para si, atribuindoas à sua categoria. Tudo leva a crer que, em alguns momentos, os professores aceitam parcialmente as críticas que fazem à categoria. Não explicitam verbalmente nas entrevistas, mas a situação pode ser depreendida da "vergonha" que alguns relatam sentir - sentimento que, conforme Goffman, é uma possibilidade central no processo de estigmatização. De todos os modos, esses mecanismos reforçam, mais uma vez, o complexo processo de construção identitária.

Mesmo o fato de um professor ser destacado como herói na mídia ${ }^{45}$, por um feito

45 É o caso, por exemplo, da professora Amanda Gurgel (Rio Grande do Norte), cujo vídeo foi visto por milhões de pessoas na internet e que chegou a participar de programas de auditório em rede nacional depois de ganhar notoriedade, em 2011. 
seu, também poderia se inscrever nesse processo:

Cada vez que alguma pessoa que tem um estigma particular alcança notoriedade, seja por infringir a lei, ganhar um prêmio ou ser o primeiro em sua categoria, pode-se tornar o principal motivo de tagarelice de uma comunidade local; esses acontecimentos podem até mesmo ser notícia nos meios de comunicação da sociedade mais ampla. De qualquer forma, todos os que compartilham o estigma da pessoa em questão tornam-se subitamente acessíveis para os normais que estão próximos e tornam-se sujeitos a uma ligeira transferência de crédito ou descrédito. Dessa maneira, sua situação leva-os facilmente a viver num mundo de heróis e vilões de sua própria espécie. (GOFFMAN, 2008, p. 37)

Um tipo especial de estigmatização ocorre também, ainda segundo Goffman, quando um indivíduo possui uma "imagem pública", que fica reduzida a certas características conhecidas pela sociedade. Esse é um mecanismo próprio dos meios de comunicação massivos, e poderíamos traçar aqui um paralelo com a imagem pública de um professor "genérico" (ou o papel social de professor) que analisamos neste estudo. Em que medida a imagem geral do professor estigmatizado é atribuída aos indivíduos professores, em particular? Essa generalização opera quando uma pequena seleção de fatos, que podem ser verdadeiros em situações específicas para determinado professor, expandem-se "até adquirir uma aparência dramática e digna de atenção, sendo, posteriormente, usados como um retrato global" (GOFFMAN, 2008, p. 82). Essa imagem pública que se forma a partir daí transforma-se em "demandas virtuais" (favoráveis ou desfavoráveis) que podem ser atribuídas aos demais professores pelos indivíduos com quem se relacionam habitualmente em sua vida diária.

Todas essas nuances da estigmatização de que tratam os autores, nós observamos nos relatos dos professores entrevistados e foram destacadas ao longo dos perfis: a vergonha (ao falar de reportagens de tom acusatório), a opção pelo afastamento, a insegurança, o medo, a assunção de críticas destinadas ao grupo e mesmo a culpabilização de colegas (por serem desunidos, por não terem lutado o suficiente) e, por fim, o silêncio. Tudo leva a crer que, numa estratégia de autopreservação, os docentes evitam a exposição, já que falar dos problemas pode contribuir para o reforço do próprio estigma. 


\subsection{Variações do Silêncio}

Neste momento, vale retomar a questão do silêncio ou, mais precisamente, a ausência dos professores no debate público sob outro prisma. É notável o fato de que, visto de perto, o silêncio revela-se menos homogêneo: há os vetos e retaliações explícitas mas, também, há variações menos visíveis como o recuo e a busca pela invisibilidade.

Em primeiro lugar, fica evidente que o silenciamento não se trata necessariamente de apatia ou ausência de criticidade. Os professores têm, sim, posicionamentos e opiniões. No entanto, há uma fissura entre o que identificamos como debate público (Capítulo 1) e as análises que os professores fazem de questões educacionais. Confrontados com os problemas do cotidiano escolar, principalmente a indisciplina e as defasagens de aprendizagem, os docentes não evocam em suas falas as políticas públicas apresentadas e discutidas na mídia como soluções para os problemas educacionais - no momento em que esta pesquisa estava sendo produzida, eram temas frequentes na imprensa, por exemplo, a disputa pelo Plano Nacional de Educação, suas metas e seu financiamento - nenhum deles mencionados nas entrevistas. À luz dessa constatação pode-se compreender a percepção, manifestada por vários dos entrevistados, de que a sociedade não conhece a realidade da escola, e que a mídia não reflete os verdadeiros problemas educacionais.

Além desse descompasso, identificamos que o silêncio se manifesta de forma diferente a depender do contexto em que a fala é solicitada - análise que está de acordo com a contribuição teórica de Bernard Lahire, que aborda as variações disposicionais de um mesmo indivíduo em um mesmo momento de sua vida em função dos domínios e contextos em que circula.

Esse quadro teórico permite considerar as propriedades dos contextos em microssituações ou tipos de interação particular. Neste particular, ao menos três variações com relação ao processo de silenciamento puderam ser captadas na análise do material verbal registrado no âmbito desta pesquisa e precisam ser historiadas. 
A primeira delas acontece quando se trata do professor ou a professora em interação com colegas na Sala dos Professores e em momentos coletivos de trabalho pedagógico, discutindo problemas de seu cotidiano ou temas educacionais mais amplos. Nesse caso, são ativadas as disposições críticas para o debate e, a depender das relações entre os docentes, para a manifestação de divergências; são vários os professores que disseram "falar demais na Sala dos Professores", ou "bater boca" em conselhos de classe, por exemplo. Essas situações podem indicar a disposição identificada acima como "recolhimento ao privado", já que a interação com os pares, muitas vezes, é colocada explicitamente nessa esfera, como no exemplo a seguir:

- Essas críticas que você tem, assim, a como as coisas estão, né; você acha, que você tem onde... você costuma conversar, você costuma falar sobre, ou tem um espaço assim que você pode...

- Na escola a gente fala muito.

- Na Sala dos Professores...

- Na Sala dos Professores a gente fala muito... Em casa nós discutimos muito isso, nós falamos muito isso, eu, meu marido e os meus filhos, a gente tem esse espaço.

- Mas levar, assim, para outras instâncias?

- Nunca tive essa pretensão. Nem sei se eles vão me receber, me ouvir. Não sei se nós seremos ouvidos. [Dalva]

Além da Sala dos Professores e momentos de reunião pedagógica, outros espaços de trocas entre colegas são identificados, como os cursos de formação continuada proporcionados pela rede de ensino. Nesses espaços, considerados como um dos poucos canais institucionais em que a troca sobre as práticas pedagógicas é possível na presença de representantes do estado, os professores veem-se em condições mais favoráveis para manifestar suas opiniões, e muitas vezes o foco das formações é desviado para os relatos e desabafos sobre os problemas do cotidiano. Questionada sobre sua participação em cursos e seminários de formação das redes em que atua, por exemplo, Dalva afirmou estar sempre presente. Não vê esses espaços, no entanto, como fóruns de debate. Caso assim fosse, julga que exporia suas opiniões acerca da atual situação do ensino público: 
- E debate, assim, que você possa falar [você já participou]?

- Só se for aqui na escola, nunca num lugar que tivesse que fazer um debate não, nunca fui; se eu tiver que falar também, eu vou meter a boca, meu marido diz que eu falo demais.

- Mas fala... Meter a boca em que sentido? Assim, de criticar...

- Eu vou falar o que eu penso, o que eu acho, entendeu. Eu tenho saudade da escola onde o aluno vinha para aprender, que ele sentava no banquinho de escola e ele realmente aprendia, e valorizava aquilo que ele estava aprendendo.

Como segunda variação do processo de silenciamento, podemos destacar o professor ou professora em interação com jornalistas ou outros profissionais que requisitam sua opinião de forma pública. Nessas situações, há uma diversidade de comportamentos identificados. Ele/a pode manifestar insegurança com relação às próprias opiniões e declarar-se não apto/a a falar sobre o assunto requisitado; pode sentir medo de represálias (que ele aprendeu a reconhecer no decorrer de sua experiência profissional) e decidir não se pronunciar; e pode, como tem se apresentado com menor frequência, emitir sua opinião.

Por último, o processo de tornar-se pouco visível revela-se quando o professor ou professora interage com a direção ou coordenação pedagógica de sua unidade escolar. Um mesmo indivíduo pode manifestar-se de forma mais crítica ou não no ambiente profissional a depender da relação desenvolvida com os outros funcionários e o histórico dessa interação. Por exemplo, um mesmo professor relatou comportamentos diferentes em duas escolas que leciona, identificando uma instituição como mais autoritária que a outra. Sobressaem-se, ainda, as falas a respeito de um passado ainda muito vivo: o tempo em que o professor, hoje efetivo, foi eventual e sofria ameaças explícitas ou veladas por essa condição (conforme Cap. 2).

A partir do exposto, poderíamos, portanto, inferir que as condições objetivas vividas pelos professores articularam-se às suas experiências de ordem subjetiva. Foram mapeadas, assim, as condições de possibilidade para a formação de disposições e/ou predisposições para o silêncio e o recolhimento ao âmbito privado.

Contudo, como este se trata de um fenômeno dinâmico, esses mecanismos não acontecem de forma linear. É um processo marcado por tensões e conflitos, a exemplo 
do que acontece na construção das identidades pessoais e profissionais - em que, neste caso, os sujeitos rejeitam parte da identidade atribuída na tentativa de reivindicar outra, mais valorizada. Submetidos a essas condições, que hoje se traduzem em um processo de estigmatização, os professores desenvolvem estratégias de autodefesa e preservação de sua autoimagem, o que pode significar fechar-se entre seus pares e evitar a exposição pública por meio de uma imprensa que, hoje, é também responsável pela perpetuação do estigma.

Em síntese, recuperando brevemente as ideias centrais do capítulo, conseguiu-se identificar e analisar como a dialética do social - ou seja, a interiorização, objetivação e exteriorização da realidade -, realizou-se nos casos aqui estudados. Dessa maneira, foi possível revelar como uma realidade objetiva, construída de maneira desfavorável à imagem do professor, articulou-se de maneira oculta, porém insidiosa, na formação de suas identidades, bem como nas diferentes maneiras de expressarem um silêncio. 


\section{CONSIDERAÇõES FINAIS}

O problema da "ausência" das vozes docentes no jornalismo educacional - que chamamos, aqui, de silêncio dos professores - propõe questões a diversos campos do conhecimento: da Comunicação, da Educação - em aspectos pedagógicos e de políticas públicas -, da Psicologia, da Teoria Política e Democrática. Se, numa democracia, os sujeitos têm direito à livre expressão e, por outro lado, os cidadãos têm direito de acessar uma pluralidade de discursos, deve ser visto com preocupação o silenciamento da categoria docente - categoria que, ademais, tem como pressupostos a autonomia e a responsabilidade de formar cidadãs e cidadãos igualmente críticos.

Como chegamos, então, a essa situação em que aqueles responsáveis pela formação crítica de seus educandos encontram-se privados - ou estão se privando - de sua palavra e, consequentemente, de sua possibilidade de ação efetiva (Cf. capítulo 1) sobre o mundo? Em que tipo de sociedade isso é possível?

Para lidar com seus múltiplos fatores e causas, propusemo-nos a transformar o "silêncio" em problema sociológico, tratando-o como uma construção social, como resultado de um processo de socialização. Objeto central da Sociologia, a investigação da relação indivíduo $x$ sociedade permitiu-nos compreender a questão como resultado de um feixe de condições objetivas e subjetivas do mundo social e também como produto de um momento histórico particular. Com o uso dessa imaginação sociológica, foi possível tornar mais nítida a teia de interdependências e as conexões humanas implicadas nesse fenômeno, os diversos agentes (jornalistas, famílias, estudantes e os próprios professores) e instituições (escola, centros de formação, Estado) que participam dessa configuração.

Para esta pesquisadora, graduada em Comunicação Social e com vivências no campo da Educação, o diálogo com a Sociologia não era um caminho exatamente fácil. Nesse percurso, porém, pudemos nos apropriar do aporte de teóricos clássicos e contemporâneos do mundo social e a abordagem sociológica mostrou-se extremamente proveitosa para avançarmos na compreensão desse problema aparentemente já tão 
naturalizado, tão “cotidiano".

Com o desenvolvimento do capítulo 2 ("Da Concretude do Silêncio") chegamos a um panorama dos principais elementos objetivos do mundo social que formam o contexto, as "forças externas" dessa configuração, com dados que emergiram das entrevistas realizadas e de material bibliográfico levantado. São as condições de trabalho, de vida, de formação e as representações e imagens sobre os professores que circulam na mídia. Ou, nas palavras de Miguel Arroyo, fixadas como epígrafe do capítulo, os trens que não chegam, os salários não recebidos, a dignidade nas condições de trabalho sempre adiada: circunstâncias sociais capazes de nos fazer e desfazer.

Dialogamos, nesse exercício de compreender a realidade objetiva que permeia a vida dos professores, com autores como Norbert Elias, Claude Dubar, Peter Berger e Thomas Luckmann, que exploraram, a seu tempo, as dinâmicas da dialética fundamental da sociedade, as relações entre as forças externas e internas ao indivíduo e a construção de suas identidades pessoais e profissionais.

De Norbert Elias, Ulrich Beck e Elisabeth Beck-Gernsheim procuramos compreender de que forma essa dinâmica acontece no mundo atual, e com isso pudemos enxergar o "silêncio" em sua interface com a condição moderna e o sentimento de isolamento que apareceu de forma tão marcada em todas as entrevistas realizadas. A inspiradora leitura de Elias, de quem tomamos o conceito de configuração, foi, ainda, fundamental para termos sempre em vista a inserção dos indivíduos em uma teia de interdependências.

Nessa perspectiva teórica, era importante não apenas olhar para o aspecto macrossocial, mas também ter foco nos indivíduos e nos processos de incorporação e formação de suas disposições - a configuração em seu aspecto microssocial. O capítulo 3 (“A Subjetivação do Silêncio - Uma Construção Social”) buscou a articulação com o capítulo precedente ao identificar as marcas das estruturas sociais nas subjetividades dos professores - ou seja, o processo de subjetivação da realidade.

Nesse ponto, para descrever o funcionamento desse processo de silenciamento nos indivíduos, o aporte teórico de Bernard Lahire foi essencial. Com um olhar sobre as histórias de vida e as diversas condições a que os professores estão submetidos socializadoras, administrativas ou legais, e de formação das suas identidades - pudemos 
reconhecer a heterogeneidade do silêncio, problematizá-lo e até mesmo colocá-lo em questão. Lidamos, no decorrer da análise, com uma diversidade de contextos e uma multiplicidade de práticas dos professores com relação à sua participação nas questões educacionais.

Entre as condições socializadoras, viu-se como a inserção precária no Ensino Superior, as condições de trabalho extenuantes e a luta por sobrevivência são capazes de formar ou acionar disposições para o recolhimento ao âmbito privado. Por outro lado, vimos como, sob outras condições tais como o acesso a uma formação acadêmica mais sólida ou a inserção em uma rede de ação política, outras disposições mais favoráveis ao debate público podem ser acionadas, não sem dificuldades.

Com as condições administrativas e legais, revelou-se uma série de mecanismos e dispositivos utilizados para o cerceamento da liberdade de expressão dos professores que, muitas vezes, apesar de ilegítimos, foram naturalizados e são reproduzidos pelos professores em suas redes de relações. As regras, veladas ou explícitas, são constantemente utilizadas como ameaças e por vezes funcionam como desencadeadoras de autocensura. Assim, o modo como a escola e o Estado se estruturam são traduzidos em sentimentos, percepções e imprimem sensações no próprio corpo dos professores entrevistados. Isso faz com que, por exemplo, mesmo os professores que nunca vivenciaram situações de interação com jornalistas sintam-se desconfortáveis e rejeitem a ideia de fazê-lo.

Também se revelaram nesse caminho as condições identitárias dessa atual configuração. De fato, há um conflito vivido pelos professores entre a imagem que lhes é atribuída e aquela que reivindicam para si: se a docência representou, para as professoras e professores entrevistados, melhora de vida e motivo de orgulho em suas famílias, como conviver com a tão desgastada e desvalorizada imagem social do professor, a quem se culpabiliza por toda sorte de problemas educacionais enfrentados hoje? Embora sejam, em parte, rejeitadas, essas imagens depreciativas, que circulam na mídia e, de modo mais amplo, na sociedade, constituem-se como vetores de um processo de estigmatização, que por sua vez torna-se realidade subjetiva, gerando medo, vergonha e insegurança - condições incompatíveis com a participação plena em um debate público.

Diante dessas condições, os sujeitos, conhecedores e participantes do "jogo" 
social, definem estratégias que estão a seu alcance (ou seja, estratégias possíveis a partir de suas diversas experiências socializadoras e de seu "estoque" de disposições). O recolhimento ao âmbito privado é a forma mais evidente delas. Com as entrevistas realizadas no âmbito desta pesquisa, identificamos uma fissura entre o ambiente escolar (mais especificamente, a "sala dos professores", ou o ambiente de interação do corpo docente) e da porta da escola para fora, ou seja, o espaço público de maneira ampliada (mídia, debates e outros fóruns).

Os docentes não se reconhecem na mídia e em espaços de elaboração de políticas educacionais, e também não reconhecem esses espaços como meios de intervenção possíveis. A depreender das falas dos professores entrevistados, ou porque sabem que lhes é negada essa participação e o reconhecimento de suas capacidades, ou por acreditarem que esses canais não lhe são, mesmo, destinados.

Apesar de seus limites, o principal ganho desta pesquisa é o de não só ter jogado luz sobre a existência do problema, mas também ter procurado descrevê-lo em sua complexidade, seus contornos e nuances. De fato, o silêncio aqui revela-se não como ausência de criticidade dos sujeitos, mas como uma situação criada por um feixe de condições, objetivas e subjetivas, a que estão submetidos e do qual também são artífices. Seu enfrentamento, portanto, sugere uma ação também em múltiplas frentes.

Além de revelar a existência de um silenciamento dos professores e suas nuances, este estudo também aponta para questões a serem aprofundadas em outros campos de pesquisa e tópicos a serem levados em conta por produtores de informação, gestores e pelos próprios professores.

Para o Jornalismo, temos, por um lado, a reflexão sobre a responsabilidade dos repórteres, editores e dos veículos de comunicação sobre a produção e disseminação de imagens da docência e, de modo mais amplo, da educação pública. Como ressaltado anteriormente, o tratamento que hoje vem sendo dado em geral às pautas educacionais reforça o estigma sobre a já desvalorizada imagem do professor e não contribui para o debate esclarecido acerca dos problemas que afligem a educação. Não se trata de mascarar a realidade, mas, ao contrário, trazer à tona na produção jornalística a complexidade de fatores que afetam a educação para além do "desempenho" docente para citar apenas alguns deles, temos as condições de trabalho e de formação dos docentes, o isolamento da escola de sua rede de proteção social, as questões de 
financiamento e os desafios pedagógicos introduzidos pela constante emergência de novas tecnologias.

Por outro lado, o Jornalismo deve estar atento a esse processo de silenciamento que acaba por privá-lo de uma das principais fontes de informação capazes de avaliar a execução das políticas educacionais: os professores da educação básica. Se, na busca de suas opiniões, o repórter depara com negativas dos docentes para entrevista, com reações que sugerem medo ou com casos concretos de retaliação, deve estar disposto a denunciar o problema para que este seja posto na ordem do dia do debate público sobre educação.

Com o conhecimento desse quadro responsável pelo processo de silenciamento, não pode mais ser possível para o repórter aceitar como natural a dificuldade em ouvir professores para suas matérias, nem deixar passar despercebido aos leitores o fato de que muitos dos professores apenas aceitem dar declarações "em off", ou com suas imagens ou vozes distorcidas para evitar a identificação.

Para o campo da pesquisa em Educação, ficam questões sobre como enfrentar o silêncio desde os cursos de formação até as formas de organização escolar. Por tudo o que se colocou até aqui, a participação crítica no debate educacional não pode ser colocada como mais uma "competência" que os professores devem adquirir para cumprirem adequadamente sua função. Muitas vezes, o discurso do "professor reflexivo", que pode ser encontrado na produção acadêmica sobre os professores, sustenta, por exemplo, que estes devem aprender a dialogar com a sociedade, como ilustra o trecho a seguir:

O envolvimento ativo e crítico para o qual seria importante preparar os professores limitar-se-ia, portanto, a esses quatro níveis [...]: 1) Aprender a cooperar e trabalhar em rede. Atualmente, os professores não são obrigados a trabalhar juntos [... 2) Aprender a vivenciar o estabelecimento de ensino como uma comunidade educativa. [...] 3) Aprender a se sentir membro efetivo e garantir uma profissão verdadeira [... 4) Aprender a dialogar com a sociedade. [...] Uma parte dos professores envolve-se com a vida política como cidadãos. Mas, nesse contexto, trata-se de que se envolvam como professores. Não como um grupo profissional que defende interesses de sua categoria, mas como profissionais que colocam sua especialização a serviço do debate sobre as políticas educacionais. (PERRENOUD, 2002, p. 201-202) 
O autor coloca, aqui, forte ênfase sobre o processo de formação dos professores, que daria os instrumentos para o necessário e espontâneo envolvimento no debate sobre as políticas educacionais. Mas todo o raciocínio exposto neste estudo procura ir em outro sentido: reconhece a importância do envolvimento crítico e de processos formativos que valorizem o debate; mas reconhece, também, que as condições objetivas e subjetivas vividas hoje pelos professores não produzem disposições favoráveis ao exercício dessa reflexividade.

Não se trata de uma capacidade que pode ser mobilizada à vontade pelos indivíduos, mas de disposições e, portanto, "inclinações relativamente mais permanentes" (LAHIRE, 2002, p. 331). Dessa forma, mesmo que os professores "aprendam" e acreditem que o debate é necessário, podem viver um "descompasso entre as crenças e as disposições a agir, ou entre as crenças e as possibilidades reais de ação" (p. 333).

No campo da pesquisa e na proposição de políticas educacionais, o "silêncio" revela a necessidade de se pensarem mecanismos efetivos de escuta dos docentes, assim como planos de carreira capazes de superar a atual fragmentação e insegurança vivida pelos professores e equipe pedagógica. Também se faz necessária a reflexão sobre como tornar mais transparentes as regras que disciplinam a entrada de jornalistas na escola e as possibilidades de expressão de professores (e servidores públicos em geral) em meios de comunicação, já que a existência do problema, embora tenha ficado evidente no decorrer desta pesquisa, foi até hoje negada pelos órgãos competentes ${ }^{46}$.

Vimos como o problema do "silêncio" dos docentes abordado aqui é profundamente conectado ao debate sobre a valorização dos professores, e isso desde o discurso dos gestores às campanhas midiáticas. Dessa maneira, os achados desta pesquisa também servem como argumentos para que o debate sobre a urgente valorização das e dos docentes não seja tratado de forma isolada, como acontece frequentemente, quando fica restrito apenas à dimensão simbólica dessa valorização.

46 Em resposta ao Observatório da Educação sobre a existência de normas restritivas para a expressão de professores em entrevistas, a Secretaria de Estado da Educação de São Paulo esclareceu que "esta gestão jamais puniu qualquer professor da rede por ser entrevistado". Disse também que "a pasta é amplamente favorável à liberdade de expressão, dos professores e de qualquer pessoa." (AÇÃO EDUCATIVA, 2008, p.19) 
Desconectado das condições socializadoras e administrativas às quais os docentes estão submetidos, esse debate pouco pode avançar, e as medidas tomadas têm poucas chance de serem efetivas.

Por fim, ainda que possa ganhar traços pessimistas na descrição de uma realidade muitas vezes massacrante, esta pesquisa buscou a interpretação de uma realidade que possa também ser utilizada como instrumento de resistência pelos professores e professoras imersos nessa trama social. Afinal, explicitar a existência de forças externas aos sujeitos, que os levam a agir de certa maneira, não significa negarlhes a autonomia e a capacidade de ação. Pelo contrário, como já apontado anteriormente em referência a Norbert Elias, somente compreendendo melhor a natureza dessas forças coercitivas é que poderemos ter esperança de adquirir algum controle sobre elas. 


\section{REFERÊNCIAS}

AÇÃO EDUCATIVA. A Cobertura da Educação na Mídia: algumas recomendações para a democratização do debate. São Paulo, 2007a. Disponível em: <www.observatoriodaeducacao.org.br/images/publicacoes/pdfs/coberturadaeducacao.pd f>. Acesso em: 27 abr. 2014. n. 24, $2007 b$.

Desafios da Conjuntura: O silêncio do professorado na educação. São Paulo,

Desafios da Conjuntura: Por que os professores faltam ao trabalho? São Paulo, n' 29, 2010.

et al. Dossiê O Silêncio do Professorado: Restrições Ilegítimas à Liberdade de Expressão dos Profissionais da Educação. São Paulo, 2008.

ALVES, T.; PINTO, J. M. R. Remuneração e características do trabalho docente no Brasil: um aporte. Cadernos de Pesquisa, São Paulo, v. 41, n. 143, p. 603-635.

ANDI. Educação na Imprensa Brasileira: responsabilidade e qualidade da Educação. Brasília, 2005.2 Disponível em: <http://www.andi.org.br/sites/default/files/Educa\%C3\%A7\%C3\%A3o\%20na\%20Impre nsa.pdf $>$. Acesso em: 27 abr. 2014.

2009.

Educação no Brasil: guia de referência para a cobertura jornalística. Brasília,

ARROYO, M. G. Ofício de mestre: imagens e auto-imagens. Petrópolis, RJ: Vozes, 2000.

BECK, U.; BECK-GERNSHEIM, E. Individualization: Institucionalized Individualism and its political and social consequences. London, Sage Publications: 2002.

BERGER, P.; LUCKMANN, T. A construção social da realidade. Petrópolis: Vozes, 2011.

BOURDIEU, Pierre. Méditations pascaliennes. Paris: Éditions du Seuil, 1997

BRANDÃO, Z. Pesquisa em Educação: conversas com pós-graduandos. Rio de Janeiro: Editora PUC-Rio; São Paulo: Loyola, 2002.

CAMPAGNUCCI, F. O debate sobre a Lei do Piso Salarial Nacional para o magistério no STF: avanços e desafios para o direito à educação no Brasil. In: XIMENES, S. B (Org.). Lei do Piso no STF: debates sobre a valorização do magistério e o direito à educação. São Paulo: Ação Educativa; Campanha Nacional pelo Direito à Educação, 2011.

CARVALHO, M. P. Trabalho docente e relações de gênero - Algumas indagações. Revista Brasileira de Educação, n. 2, 1996, p. 77-84. 
No coração da sala de aula: gênero e trabalho docente nas séries iniciais. São Paulo: Xamã, 1999.

CITELLI, A. Educomunicação: imagens do professor na mídia. São Paulo: Paulinas, 2012.

CONTRERAS, J. A autonomia de professores. São Paulo: Cortez, 2002.

DUBAR, C. A socialização: construção das identidades sociais e profissionais. Porto: Porto Editora, 1997.

A socialização: construção das identidades sociais e profissionais. São Paulo: Martins Fontes, 2005.

A crise das identidades: a interpretação de uma mutação. São Paulo: Editora da Universidade de São Paulo, 2009.

ELIAS, N. A sociedade dos indivíduos. Rio de Janeiro: Jorge Zahar, 1994.

2006.

Escritos e Ensaios - Estado, Processo, Opinião Pública. Rio de Janeiro: Zahar,

; SCOTSON, J. Os Estabelecidos e os Outsiders. Rio de Janeiro: Jorge Zahar, 2000 .

FERREIRA, M. O. V. Somos todos trabalhadores em Educação? Reflexões sobre identidades docentes desde a perspectiva de sindicalistas. Revista Educação e Pesquisa, São Paulo, v. 32, n. 2, p. 225-240, maio/ago. 2006.

FERREIRA, R. Magistério, mídia e imagem: O jogo das expectativas. In OLIVEIRA, Valeska Fortes (Org.). Imagens de professor: significações do trabalho docente. Ijuí: Editora UNIJUÍ, 2000.

FREIRE, P. Pedagogia do oprimido. Rio de Janeiro: Paz e Terra, 2005.

GATTI, B. A. et al. A atratividade da carreira docente. São Paulo: Fundação Carlos Chagas, 2009.

GOFFMAN, E. Estigma: notas sobre a manipulação da identidade deteriorada. Rio de Janeiro: LTC, 2008.

A Representação do Eu na Vida Cotidiana. Petrópolis: Vozes, 2009.

GOMES, W.; MAIA, R. C. M. Comunicação e Democracia: Problemas e perspectivas. São Paulo: Paulus, 2008.

KAUFMANN, J. L’entretien compréhensif. Paris: Nathan, 1996.

LAHIRE, B. Homem Plural: os determinantes da ação. Petrópolis: Vozes, 2002.

Retratos sociológicos: disposições e variações individuais. Porto Alegre: Artmed, 2004.

LIMA, V. A. de. Comunicação e cultura: as ideias de Paulo Freire. Brasília: Editora Universidade de Brasília; Fundação Perseu Abramo, 2011. 
NÓVOA, A. Formação de professores e formação docente. In: Os professores e a sua formação. Lisboa: Dom Quixote, 1992.

Os Professores na Virada do Milênio: do excesso dos discursos à pobreza das práticas. Revista Educação e Pesquisa, São Paulo, v. 25, n. 1, p. 11-20, jan./jun., 1999.

Os professores e o "novo" espaço público da educação. In: TARDIF, M.; LESSARD, C. (Orgs.). O ofício de professor: Histórias, perspectivas e desafios internacionais. Petrópolis: Vozes, 2009.

PEREIRA, Luiz. O magistério primário numa sociedade de classe. São Paulo: Pioneira, 1969.

PERRENOUD, P. A Prática Reflexiva do Ofício de Professor: profissionalização e razão pedagógica. Porto Alegre: Artmed, 2002.

SETTON, M. G. J. Professor: um gosto de classe. 1989. 135 fls. Dissertação (Mestrado em Ciências Sociais) - Pontifícia Universidade Católica de São Paulo, São Paulo, 1989.

A noção de socialização na sociologia contemporânea: um ensaio teórico. In Boletim SOCED, v. 6, p. 1-20, 2008.

TEDESCO, J. C. Profesionalización y capacitación docente. Buenos Aires: IIPEUNESCO, 2002.

UNESCO. O perfil dos professores brasileiros. São Paulo: Moderna/Instituto Paulo Montenegro/INEP/MEC, 2004.

VIANNA, Cláudia. Os nós dos "nós": crise e perspectivas da ação coletiva docente em São Paulo. São Paulo: Xamã, 1999. 


\section{ANEXO - ROTEIRO PARA ENTREVISTA SEMIESTRUTURADA}

Objetivo - apreender, por meio dos discursos dos entrevistados, representações, percepções e imagens dos professores acerca de sua profissão e de sua presença no debate educacional

\section{Dados pessoais/socioeconômicos}

1. Fale-me um pouco sobre sua trajetória: onde nasceu, em que data...

2. Qual era a ocupação de seus pais?

3. É casada? Se sim, há quanto tempo? O que faz seu cônjuge?

4. Tem filhos?

5. Como foi sua trajetória escolar?

\section{Escolha da profissão/formação}

6. Como tomou a decisão de ser professora?

7. O que esperava da carreira à época?

8. Quais são os pontos positivos e os negativos à profissão docente?

9. Qual é sua formação? Onde se formou?

\section{Trabalho}


10. Que disciplinas leciona atualmente? Para qual etapa de ensino?

11. Há quanto tempo leciona? E na rede estadual?

12. Com que tipo de vínculo de trabalho (concursada, temporária...)

13. Leciona em outras redes ou tem outro emprego?

14. Conte-me um pouco sobre sua rotina (cuidados com a casa, família, trabalho, deslocamento...)

15. Há quanto tempo leciona na atual escola?

16. Fale sobre a rotina em sala de aula (relação com os alunos)

17. Como é dar aula nesta escola do Estado?

18. Como é sua relação com o(a) diretor(a), com os outros professores, com a comunidade?

\section{Lazer/Tempo livre}

19. O que costuma fazer em seu tempo livre? O que gosta de fazer?

20. Frequenta que tipo de espaços?

21. O que usa para se informar?

22. Acompanha notícias da área de educação? Como?

\section{Atuação política}

23. Acompanha o sindicato dos professores? Qual? O que pensa do sindicato?

24. O que pensa sobre sua categoria, de maneira geral?

25. Como acha que a sociedade vê os professores? 


\section{Relação com a mídia/debates}

26. Gosta de participar de debates sobre educação? Costuma participar?

27. Já foi convidado a participar de debates ou falar publicamente em seminários sobre educação como palestrante?

28. Já teve algum contato com jornalistas em processo de escrita de reportagem sobre educação? Como foi essa experiência?

29. Acredita que há algum impedimento para professores falarem sobre suas opiniões publicamente? 